University of South Florida

DIGITAL COMMONS

Digital Commons @ University of

@ UNIVERSITY OF SOUTH FLORIDA

South Florida

\title{
Gabbroic Xenoliths and Host Ferrobasalt from the Southern Juan de Fuca Ridge
}

Jacqueline Eaby Dixon

California Institute of Technology, jdixon@usf.edu

David A. Clague

U.S. Geological Survey

Jean-Philippe Eissen

Universite Louis Pasteur

Follow this and additional works at: https://digitalcommons.usf.edu/msc_facpub

Part of the Life Sciences Commons

\section{Scholar Commons Citation}

Dixon, Jacqueline Eaby; Clague, David A.; and Eissen, Jean-Philippe, "Gabbroic Xenoliths and Host Ferrobasalt from the Southern Juan de Fuca Ridge" (1986). Marine Science Faculty Publications. 1322. https://digitalcommons.usf.edu/msc_facpub/1322

This Article is brought to you for free and open access by the College of Marine Science at Digital Commons @ University of South Florida. It has been accepted for inclusion in Marine Science Faculty Publications by an authorized administrator of Digital Commons @ University of South Florida. For more information, please contact digitalcommons@usf.edu. 


\title{
Gabbroic Xenoliths and Host Ferrobasalt From the Southern Juan de Fuca Ridge
}

\author{
Jacqueline Eaby Dixon ${ }^{1}$ and David A. Clague
}

U.S. Geological Survey, Menlo Park, California

JEAN-PHILIPPE EISSEN ${ }^{2}$

Universite Louis Pasteur, Laboratoire de Petrographie, Strasbourg, France

\begin{abstract}
Rare isotropic gabbroic xenoliths occur in sheet and lobate flow fragments of nearly aphyric ferrobasalt collected along a 12-km section of the southern Juan de Fuca Ridge. Xenoliths comprise $\ll 1 \%$ of the dredge contents and range in size from $1 \mathrm{~cm}^{3}$ (glomerocryst) to $240 \mathrm{~cm}^{3}$. The xenoliths have ophitic to intersertal texture with 5-50\% interstitial glass of ferrobasaltic composition more evolved than the host lava. On the basis of texture and mineralogy, the xenoliths have been subdivided into three types: type I, plagioclase + olıvine + glass; type II, plagioclase + augite + glass \pm olivine; and type III, plagioclase + augite + olivine + glass \pm pigeonite (partially inverted) $+\mathrm{Fe}-\mathrm{Ti}$ oxides. Mineral and glass inclusion compositions suggest a sequence of evolution for the three xenolith types in which type $I$ is the least evolved and type III is the most evolved. Application of a graphical pyroxene geothermometer to augite in xenolith types II and III yields crystallization temperatures of $1100^{\circ}-1200^{\circ} \mathrm{C}$ and to host-lamellae pairs in inverted pigeonite yields subsolidus equilibrium temperatures of $1100^{\circ}-1150^{\circ} \mathrm{C}$. Coexisting titanomagnetıte-ilmenite pairs in type III xenoliths yield temperature estimates of $1000^{\circ}-1070^{\circ} \mathrm{C}$ and $\log$ $f_{0_{2}}=-9.7$ to -10.8 . We infer that the xenoliths represent the partially crystalline "mush" boundary zone of a magma chamber based on the abundance of interstitial glass, zonation of mineral grains in the most crystalline samples, and coherence of chemical trends between interstitial glass, glass inclusions, and mineral phases. The evolved composition of the xenoliths provides evidence for the presence of melts more fractionated than the host ferrobasalt in the magma chamber. The erupted ferrobasalt is a hybrid lava formed by mixing these highly evolved melts with more primitive melts.
\end{abstract}

\section{INTRODUCTION}

Recent studies of oceanic crust suggest that size and longevity of axial magma chambers beneath oceanic spreading centers and the petrology of the erupted igneous rocks are largely a function of spreading rate. Magma chambers beneath slow spreading centers are thought to be small and in some places transitory [Stakes et al., 1984], while beneath intermediate to fast spreading centers they are steady state [Macdonuld, 1982]. A natural consequence of steady state magma chambers undergoing continuous fractionation is mixing between batches of primitive magma and resıdual differentiates. Mixing is now recognized as an important petrologic process in the generation of mid-oceanic ridge basalt (MORB) and has been invoked by various authors to explain (1) the eruption of homogeneous basalt compositions over long time periods [Usselman and Hodge, 1978], (2) the presence of anomalous phenocrysts and melt inclusions [Dungan and Rhodes, 1978], (3) the concentrations of incompatible elements in some moderately evolved compositions in excess of that predicted by simple fractional crystallization models [O'Hara, 1977; Bryan and Moore, 1977; Bryan et al., 1979; Stakes et al., 1984], (4) a reversal in mineral crystallization sequences [Walker et al., 1979], (5) magma with chemical and mass balance characteristics of plagioclase accumulation even though the lavas contain few or no plagioclase phenocrysts [Flower, 1982], and (6) the homogenelty of isotopic compositions along moderate to fast spreading centers [Cohen and O'Nions, 1982; Allegre et al., 1983; Batiza, 1984].

The role of mixing in the production of ferrobasalt, how-

\footnotetext{
${ }^{1}$ Now at Division of Geological and Planetary Sciences, California Institute of Technology, Pasadena, California.

${ }^{2}$ Now at Office de la Recherche Scientifique et Technique OutreMer, Noumea, New Caledonia.

Copyright 1986 by the American Geophysical Union.

Paper number 5B5733.

$0148-0227 / 86 / 005 \mathrm{~B}-5733505.00$
}

ever, is less certain. Clague and Bunch [1976] used linear least squares mixing models of major elements to show that ferrobasalt can be produced by shallow level fractionation of plagioclase, clinopyroxene, and minor olivine in the average proportions of $9.3: 7.7: 1$ with up to $74 \%$ of the parental magma fractionally crystallizing. Mattey and Muir [1980], on the other hand, found that a model for mixing of periodically injected batches of primitive magma with residual differentiates could more closely predict variations in major and trace elements in ferrobasalt from Deep Sea Drilling Project (DSDP) sites 424 and 425 near the Galapagos spreading center $86^{\circ} \mathrm{W}$.

Natland [1983] found no geochemical evidence for mixing between olivine tholeiite and ferrobasalt at the East Pacific Rise near the Siqueiros Fracture Zone. He argued that ferrobasalt in this area formed due to crystal fractionation in small isolated magma bodies such as dikes or shallow intrusions above larger magma chambers. Sinton et al. [1983] proposed that ferrobasalt is generated in small isolated magma bodies behind propagating rift tips. Farther behind the propagating rift tip, extreme differentiation becomes less likely as the steady state thermal configuration of a normal ridge is approached. These studies suggest that the extent of differentiation of MORB may be controlled by a delicate balance between cooling and magma supply rates.

The effects of differentiation and mixing are recorded in oceanic plutonic rocks, but at the present time, sampling of the plutonic rocks is severely biased toward the Atlantic and Indian oceans, where slow spreading rates result in large displacements along transform faults and rift valley boundaries [Engel and Fisher, 1975; Hodges and Papike, 1976; CAY TROUGH, 1979; Fox and Stroup, 1981]. Data for gabbros from intermediate to fast spreading centers are less abundant [V anko and Batiza, 1982; Hebert et al., 1983]. Moreover, interpretation of magmatic conditions is impeded by deformation, metamorphism, or brecciation of most oceanic gabbroic and ultramafic rocks. 


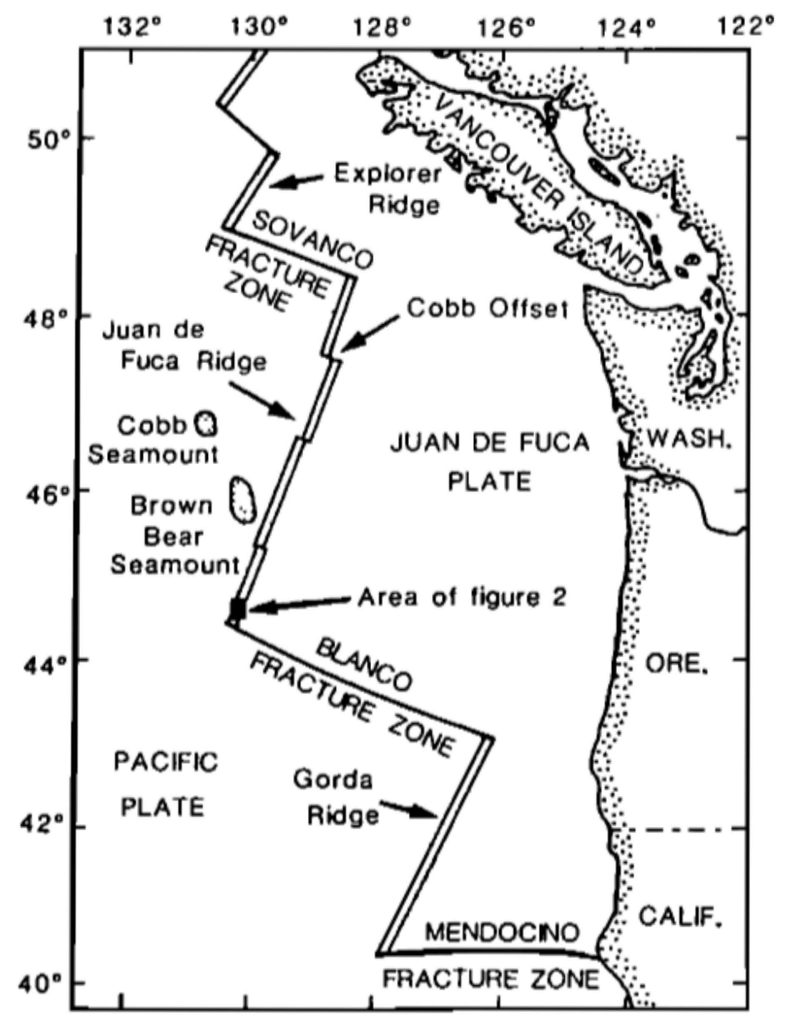

Fig. 1. Map showing location of mid-ocean ridge segments in the northeast Pacific. Location of U.S. Geological Survey study area is shown by the solid square.

Rare glass-bearing gabbroic xenoliths occur in nearly aphyric ferrobasalt collected from the southern Juan de Fuca Ridge. In this report we present major and trace element data for the host ferrobasalt and mineral phase chemistry for these unaltered gabbroic xenoliths. Detailed discussion of lava chemistry provides a framework for comparison with the gabbroic xenoliths. The data are used to evaluate the role of mixing in the formation of ferrobasalt and the longevity of subaxial magma chambers at the Juan de Fuca Ridge.

\section{Geologic Setting}

The Juan de Fuca Ridge extends $500 \mathrm{~km}$ from the Blanco Fracture Zone to the Sovanco Fracture Zone and is a moderate-rate spreading center ( $30 \mathrm{~mm} \mathrm{yr}^{-1}$ half rate) separating the Pacific and Juan de Fuca plates (Figure 1). Previous petrologic studies of basalt from the Juan de Fuca Ridge show that the southern two thirds of the ridge (south of the Cobb offset) is characterized by strongly fractionated mid-oceanic ridge basalt (MORB) with high $\mathrm{FeO}, \mathrm{TiO}_{2}, \mathrm{MnO}, \mathrm{P}_{2} \mathrm{O}_{5}$, $\mathrm{Na}_{2} \mathrm{O}$, and $\mathrm{K}_{2} \mathrm{O}$ and low $\mathrm{MgO}, \mathrm{CaO}$, and $\mathrm{Al}_{2} \mathrm{O}_{3}$ [Kay et al., 1970; Scheidegger, 1973; Detrick and Lynn, 1975; Vogt and Byerly, 1976; Wakeham, 1977; Delaney et al., 1982]. Ferrobasalt ( $>10 \% \mathrm{FeO}^{*}$, total iron calculated as $\mathrm{FeO}$ ) is particularly abundant near the Juan de Fuca Ridge-Blanco Fracture Zone intersection and $20-30 \mathrm{~km}$ south of the Cobb offset. The maximum iron and titanium enrichment in the lavas occurs behind zones identified as propagating rifts in both regions [Wilson et al., 1984].

High-amplitude mágnetic anomalies (600-1200 gammas) are spatially associated with ferrobasalt at the Juan de Fuca Ridge-Blanco Fracture Zone intersection [Vogt and Byerly, 1976]. Vogt and Byerly postulated that the iron and titanium enrichment could result from fractional crystallization in a subaxial conduit transporting magma longitudinally away from the Cobb hotspot and damming of the flow at fracture zones.

Incompatible element ratios are highly variable, both along the ridge and within single dredge hauls; most are intermediate between normal and enriched MORB [Liias and Rhodes, 1982]. The rare earth element (REE) patterns range from light REE depleted to light REE enriched with a dominance of fairly flat REE patterns [Schilling et al., 1982]. Sr isotopic ratios of basalt along the Juan de Fuca Ridge have a small range of values; the average ${ }^{87} \mathrm{Sr} /{ }^{86} \mathrm{Sr}$ ratio is 0.70249 \pm 0.00014 . Though subtle variations exist along strike, the $\mathbf{S r}$ isotopic data do not show any systematic variation relative to the Cobb hotspot [Eaby et al., 1984].

\section{STUDY AREA}

The study area is a $12-\mathrm{km}$ segment of the axial valley approximately $15 \mathrm{~km}$ north of the Juan de Fuca Ridge-Blanco Fracture Zone intersection (Figure 1). This area was selected in part due to its relatively simple tectonic setting. The ridge segment has a linear symmetrical axial rift valley and is located away from hotspots and actively propagating rifts. Preliminary descriptions of dredged lavas, dredged sulfides, and the geologic setting of the ridge segment are published elsewhere [Eaby and Clague, 1982; Koski et al., 1982; Normark et al., 1982; Morton et al., 1983]. Dredge locations and bathymetry of the study area are shown in Figure 2. The axial valley is extremely flat floored and approximately $1 \mathrm{~km}$ wide and $100 \mathrm{~m}$ deep.

Seismic reflection studies in the study area [Morton, 1984] show a weak reflector at approximately $2.3 \mathrm{~km}(0.8-1.0 \mathrm{~s})$ depth interpreted as a shallow level magma reservoir. The low amplitude of the reflection suggests that the velocity contrast across the interface is small, gradational (i.e., partially crystalline mush), or both.

Deep-tow photographic surveys of the study area [Normark et al., 1982; Lichtman et al., 1983] indicate that lava in the axial valley is dominantly sheet and lobate flow forms, characteristic of high effusion rates (Figures $3 a-3 c$ ), with rare pillows (Figure $3 d$ ), characteristic of low effusion rates. Most lava displays brilliant glassy reflections. The axial floor is smooth and unfissured outside a nearby continuous linear depression 5-25 $\mathrm{m}$ deep and $50-100 \mathrm{~m}$ wide that bisects the valley. Sediment cover within the axial valley is least $(<25 \%)$ within the central zone of collapse features and increases toward the valley margin (>25\%). Zn-rich massive sulfide deposits are aligned along the central bathymetric depression. Valley walls are dominated by pillow flows lacking glassy reflections and having $40-80 \%$ sediment cover. The inner valley walls, including a low terrace about $30 \mathrm{~m}$ above the valley floor, are formed by steep normal faults.

\section{Host Lava}

\section{Petrography and Distribution}

The recovered basalt samples from the axial rift valley are nearly aphyric with $\ll 1 \%$ phenocrysts; plagioclase (1-5 $\mathrm{mm}) \gg$ augite $(1-2 \mathrm{~mm})>$ olivine $(1-2 \mathrm{~mm})$. The samples are all nonvesicular $(<0.5 \%)$ glassy to microcrystalline basalt. Basalt morphology is dominantly sheet, lobate, and hollow lobate (blisters) flow fragments $(90 \%)$ with minor amounts of pillow fragments $(10 \%)$. The sheet and lobate flow fragments are commonly $4-8 \mathrm{~cm}$ thick and have thick glassy selvages on upper and lower surfaces. The upper glassy selvages have a maximum thickness of $13 \mathrm{~mm}$. Palagonite thicknesses range from 0 to $2 \mu \mathrm{m}$, suggesting an age of $<1000$ years [Hekinian and Hoffert, 1975]. 


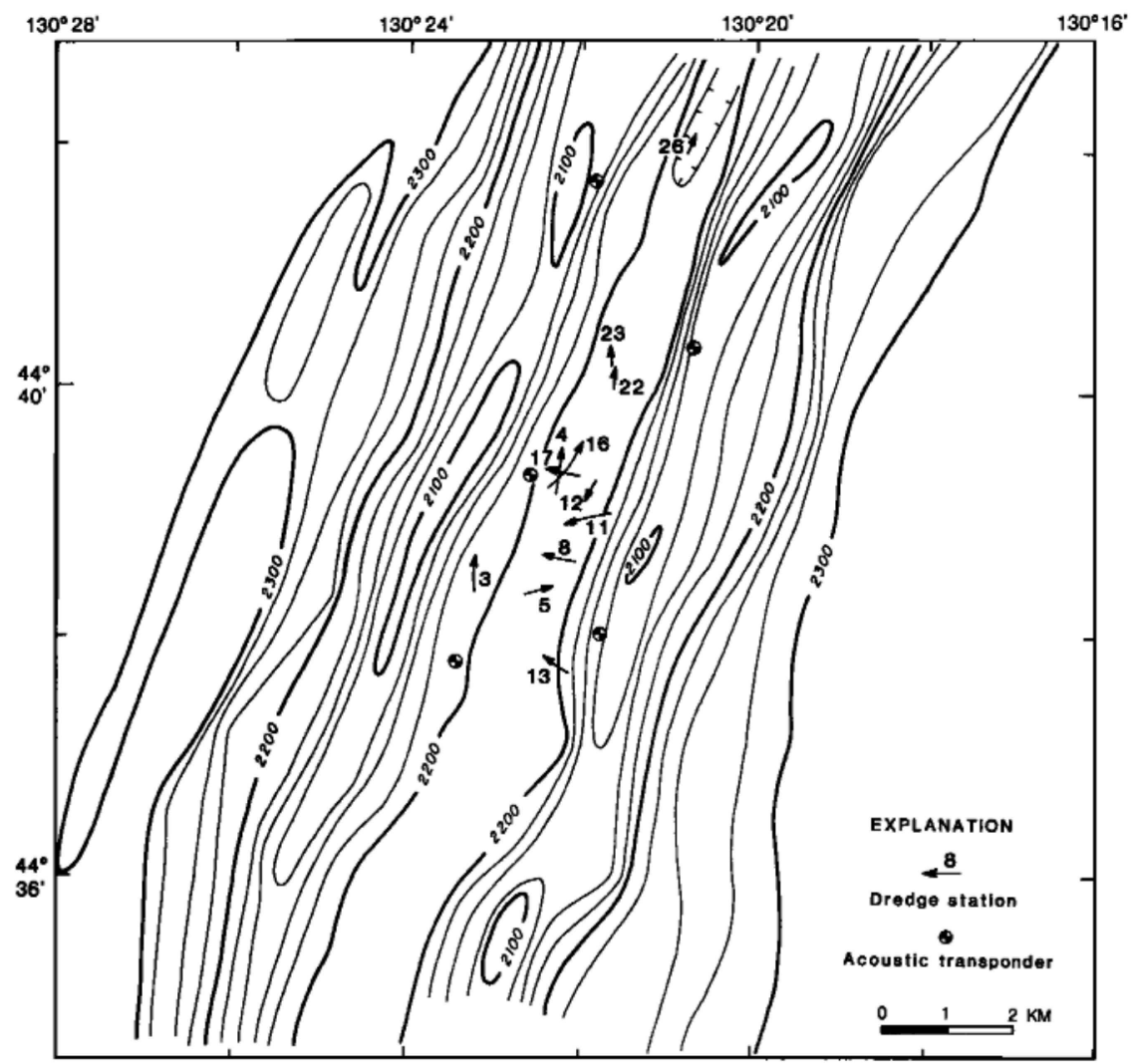

Fig. 2. Scientists aboard the U.S. Geological Survey research vessel S. P. Lee conducted acoustic transponder navigated dredging, deep-toward camera surveying, and water sampling during September 1981 (cruise L11-81-WF). Locations of dredge stations are shown with arrows indicating direction of movement of the dredge. Dredges 3, 8, and 16 sampled older material from the axial walls. Contour interval is $25 \mathrm{~m}$.

Lava samples from the axial valley walls are dominantly pillow fragments texturally similar to samples from the axial valley. The outer glassy selvage has commonly spalled off leaving only a few millimeters of glass; palagonite thicknesses on original glass surfaces range from 5 to $16 \mu \mathrm{m}$, suggesting an age of $2000-5000$ years. Three small porphyritic glass fragments recovered in dredge 8 are probably from the valley walls and are the only porphyritic samples collected in the study area. These flat glass chips contain $10 \%$ total phenocrysts with plagioclase $\gg$ augite $>$ olivine. The porphyritic glass chips have the thickest palagonite and Mn-oxide coatings of all the samples. Where the dredge path could have sampled both the walls and valley, our assignment of location of the samples is based on lava age and morphology of the sampled fragments.

\section{Chemical Composition}

The host lavas for the xenoliths are mid-ocean ridge ferrobasalt that exhibits a narrow range of compositional variation. $A$ verage microprobe analyses of glassy margins of samples from each dredge are listed in Table 1 . A representative group of $16 \mathrm{X}$ ray fluorescence whole-rock major and trace element analyses were selected from a larger set of $\mathbf{3 0}$ analyses and are listed in Table 2. The lavas from the axial valley are enriched in iron and titanium $\left(\mathrm{FeO}^{*}=11.6-12.2 \mathrm{wt} \%, \mathrm{TiO}_{2}=1.8-1.9\right.$ wt $\%, \mathrm{Mg}$ number $=52.5-54.7)$ compared to normal MORB (FeO ${ }^{*}<10.0$ wt \%, $\mathrm{TiO}_{2}<1.5$ wt \%). Basalt from the axial valley walls is also ferrobasalt but exhibits a slightly wider compositional range; the most $(\mathrm{Mg}$ number $=50.3$ ) and least $(\mathrm{Mg}$ number $=60.4)$ differentiated lavas are from the valley walls.
Normative compositions of the nearly aphyric lavas range from slightly (up to $1.5 \%$ ) olivine normative to slightly (up to $1.7 \%$ ) quartz normative with the vast majority of the samples being slightly quartz normative. The porphyritic sample $8-2$ is the least differentiated lava from the area and contains $3.7 \%$ normative olivine. There is a general trend of decreasing normative olivine and increasing normative quartz with increasing $\mathrm{FeO} / \mathrm{MgO}$ ratios, but higher $\mathrm{Na}_{2} \mathrm{O}$ values also force the norm toward higher normative olivine.

In general, increasing $\mathrm{FeO}^{*}, \mathrm{Na}_{2} \mathrm{O}, \mathrm{K}_{2} \mathrm{O}, \mathrm{TiO}_{2}, \mathrm{P}_{2} \mathrm{O}_{5}$, $\mathrm{MnO}$, and $\mathrm{SO}_{3}$ are coupled with decreasing $\mathrm{MgO}, \mathrm{Al}_{2} \mathrm{O}_{3}$, and $\mathrm{CaO} . \mathrm{SiO}_{2}$ concentrations show no systematic variation with increasing $\mathrm{Mg}$ number. Plots of $\mathrm{TiO}_{2}$ versus $\mathrm{FeO}^{*} / \mathrm{MgO}$ and $\mathrm{CaO}$ versus $\mathrm{MgO}$ illustrate these trends (Figures $4 a$ and $4 b$ ); data from the Galapagos spreading center at approximate longitudes of $85^{\circ}$ and $95^{\circ} \mathrm{W}$ [Byerly et al., 1976; Clague et al., 1981; Fornari et al., 1983] are plotted for comparison. The most striking aspect of the data set is the chemical homogeneity of samples from the axial valley. The 24 whole-rock $X$ ray fluorescence analyses of lavas from the valley floor have an average analysis and standard deviation of $\mathrm{SiO}_{2}=49.89$ $\pm 0.18, \quad \mathrm{Al}_{2} \mathrm{O}_{3}=13.65 \pm 0.08, \quad \mathrm{Fe}_{2} \mathrm{O}_{3}{ }^{*}=13.27 \pm 0.19$, $\mathrm{MgO}=6.87 \pm 0.11, \quad \mathrm{CaO}=11.10 \pm 0.10, \quad \mathrm{Na}_{2} \mathrm{O}=2.53$ $\pm 0.12, \mathrm{~K}_{2} \mathrm{O}=0.18 \pm 0.02, \mathrm{TiO}_{2}=1.86 \pm 0.04, \mathrm{P}_{2} \mathrm{O}_{5}=0.18$ \pm 0.01 , and $\mathrm{MnO}=0.21 \pm 0.01$, which is statistically identical to the analytical precision.

Trace element abundances are listed with major element analyses in Table 2 and shown on $\mathrm{MgO}$ variation diagrams in Figure 5. The range in trace element concentrations (V 308378, Cr 331-112, Ni 99.3-49.0, Zn 100-131, Ga 17.7-20.3, Rb 0.9-2.4, Sr 104.4-109.3, Y 32.1-53.3, Zr 96.9-187, Nb 2.9-6.4 

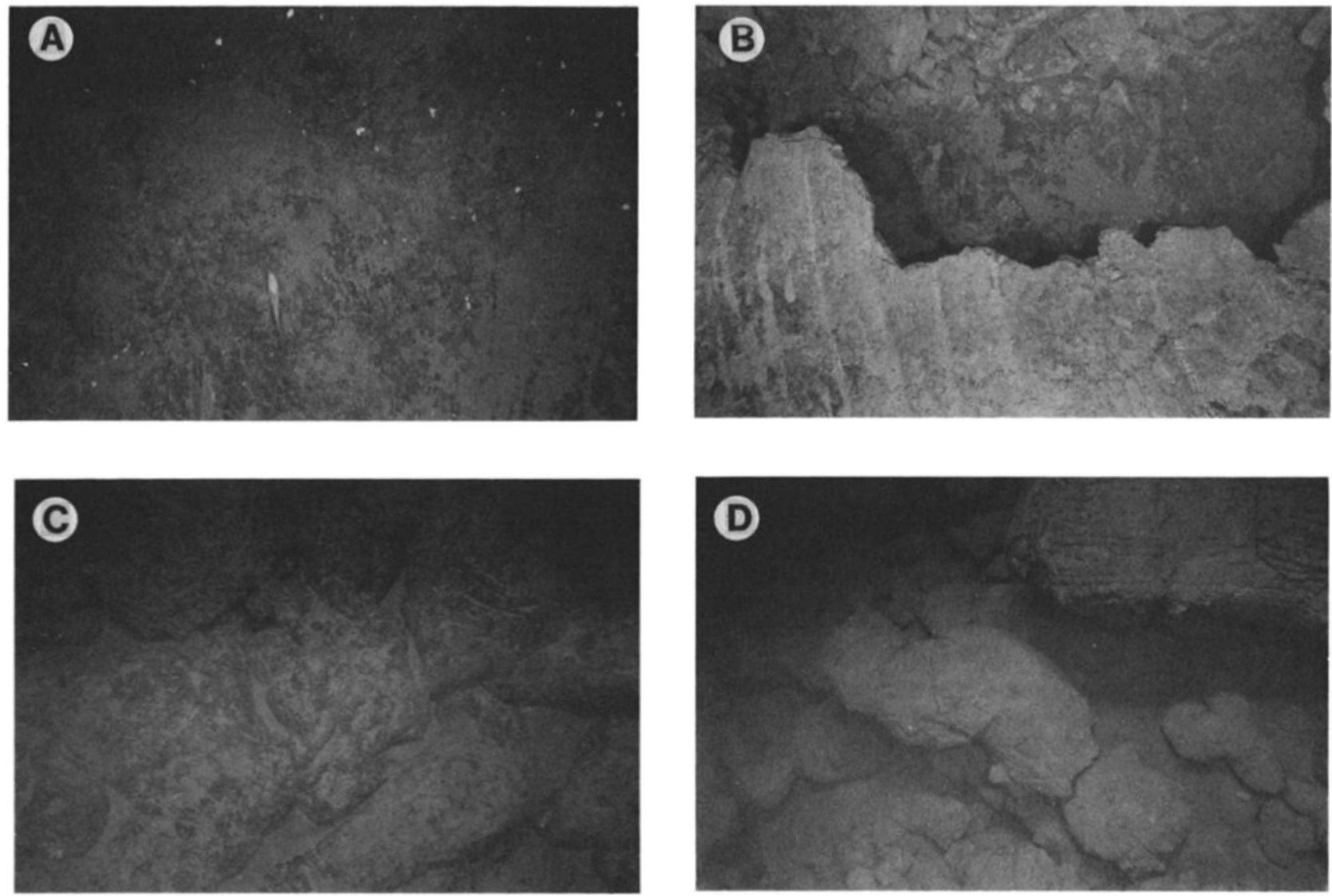

Fig. 3. Deep-tow photographs of typical basalt morphologies found in the axial valley. (a) Low-relief sheet flows with light sediment cover which forms the dominant basalt morphology in the axial valley. (b) Collapsed hollow lobate sheet flow. (c) Lobate basalt flow. (d) Pillowed basalt flow.

ppm) are similar to those found in ferrobasalt with comparable $\mathrm{FeO}^{*} / \mathrm{MgO}$ from the Galapagos spreading center [Perfit et al., 1983]. Increasing $\mathrm{FeO}^{*}$ and $\mathrm{TiO}_{2}$ are accompanied by increasing concentrations of incompatible elements $(\mathrm{V}$, $\mathrm{Zr}, \mathrm{Y}, \mathrm{Zn}, \mathrm{Nb}$ ) and decreasing concentrations of compatible elements $(\mathrm{Ni}, \mathrm{Cr})$.

Ratios of $\mathrm{Zr} / \mathrm{Nb}$ for the 24 samples from the valley average $23.4 \pm 1.1$ and are toward the less depleted range for normalMORB (N-MORB). Similarly, the valley samples have an average $\mathrm{Zr} / \mathrm{Y}$ ratio of $3.24 \pm 0.07$, an average $\mathrm{Y} / \mathrm{Nb}$ ratio of $7.21 \pm 0.4$, and an average $\mathrm{P}_{2} \mathrm{O}_{5} / \mathrm{K}_{2} \mathrm{O}$ ratio of $1.02 \pm 0.05$ (Figure $4 c$ ). These trace and minor element ratios are all within the ranges found for N-MORB elsewhere and are consistent with the low ${ }^{87} \mathrm{Sr} /{ }^{86} \mathrm{Sr}$ ratios $(0.7026)$ reported for three samples from the valley floor of this segment of the Juan de Fuca Ridge [Eaby et al., 1984]. The six analyzed samples from the valley walls, while more variable in major element composition than the 24 valley floor samples, have consistently higher $\mathrm{P}_{2} \mathrm{O}_{5} / \mathrm{K}_{2} \mathrm{O}$ ratios $(1.16 \pm 0.09), \quad \mathrm{Zr} / \mathrm{Nb}$ ratios $(28.4 \pm 2.9)$, and $\mathrm{Y} / \mathrm{Nb}$ ratio $(8.9 \pm 1.3)$.

\section{Phenocrysts and Microphenocrysts}

Plagioclase compositions are given in Tables $3 a$ and $3 b$. Plagioclase phenocrysts and microphenocrysts are weakly zoned, skeletal to euhedral laths in form, and up to $5 \mathrm{~mm}$ in length. Plagioclase phenocrysts in sample 8-2 range in composition from $\mathrm{An}_{70}$ to $\mathrm{An}_{77}$. The average composition of 46 microphenocryst analyses is $\mathrm{An}_{74.5}$ with a range of $\mathrm{An}_{70}$ to $\mathrm{An}_{84}$. Analyses with maximum and minimum An contents for several samples are listed in Table $3 a$.
Olivine occurs as euhedral, hopper, and skeletal microphenocrysts. Representative olivine microphenocryst compositions are given in Table $4 a$ and shown in Figure 6. Olivine microphenocryst compositions range from $\mathrm{Fo}_{80}$ to $\mathrm{Fo}_{\mathbf{8 3}}$. The most magnesian olivine $\left(\mathrm{Fo}_{\mathbf{8 3}}\right)$ occurs in sample 8-2.

Representative pyroxene analyses are given in Table 5 and shown on the pyroxene quadrilateral in Figure 6. Pyroxene compositions referenced in the text are expressed in terms of percent Wo, Fs, and En, where Wo is the atomic proportion $100 \mathrm{Ca} /(\mathrm{Ca}+\mathrm{Fe}+\mathrm{Mg}), \quad \mathrm{Fs}=100 \mathrm{Fe} /(\mathrm{Ca}+\mathrm{Fe}+\mathrm{Mg}), \quad$ and $\mathrm{En}=100 \mathrm{Mg} /(\mathrm{Ca}+\mathrm{Fe}+\mathrm{Mg})$. Quadrilateral components were calculated using the method of Lindsley and Andersen [1983] for comparison to Lindsley's [1983] graphical pyroxene geothermometer and are listed in Table 5. Phenocrysts of augite in sample 8-2 range in composition from $\mathrm{Wo}_{40.1} \mathrm{Fs}_{9.1} \mathrm{En}_{50.8}$ to $\mathrm{Wo}_{39.4} \mathrm{Fs}_{10.0} \mathrm{En}_{\text {50.6. }}$. $\mathrm{The} \mathrm{Cr}_{2} \mathrm{O}_{3}$ contents range from 0.60 to $1.27 \mathrm{wt} \%$ and are about a factor of 3 higher than $\mathrm{Cr}_{2} \mathrm{O}_{3}$ contents of pyroxene in the xenoliths. The phenocrysts have the most refractory compositions of all analyzed pyroxene. Composition of augite microphenocrysts in samples 22-34 and 26-13B range from $\mathrm{Wo}_{40.5} \mathrm{Fs}_{10.4} \mathrm{En}_{49.1}$ to $\mathrm{Wo}_{36.0} \mathrm{Fs}_{11.5} \mathrm{En}_{52,5}$. Compositions of phenocrysts and microphenocrysts in the host lava are similar to phenocryst compositions in Galapagos spreading center lavas [Perfit and Fornari, 1983] and Nazca plate lavas [Mazzullo and Bence, 1976].

\section{Fractionation and Source Characteristics}

Variations in major and trace element composition of ferrobasalt from the southern Juan de Fuca Ridge are similar to the variations in lavas with comparable $\mathrm{FeO}^{*} / \mathrm{MgO}$ ratic 
TABLE 1. Averaged Major Element Microprobe Analyses of Basalt Glasses

\begin{tabular}{|c|c|c|c|c|c|c|c|c|c|c|c|c|c|c|}
\hline & \multicolumn{14}{|c|}{ Dredge } \\
\hline & $3-6$ & 8 & 11 & 12 & 4 & 3 & 23 & 5 & 17 & 22 & 26 & 16 & $16-6$ & 13 \\
\hline Number of & (1) & (1) & (1) & (1) & (7) & (3) & (1) & (7) & (8) & (8) & (7) & (3) & (1) & (1) \\
\hline Location & wall & wall & valley? & valley & valley & wall & valley & valley & valley & valley & valley & valley & wall? & wall \\
\hline $\mathrm{SiO}_{2}$ & 50.8 & 50.6 & 50.8 & 50.8 & $50.6 \pm 0.1$ & $50.7 \pm 0.6$ & 51.2 & $50.5 \pm 0.2$ & $50.5 \pm 0.3$ & $50.7 \pm 0.4$ & $50.5 \pm 0.4$ & $51.0 \pm 0.3$ & 50.7 & 50.7 \\
\hline $\mathrm{Al}_{2} \mathrm{O}_{3}$ & 14.4 & 14.3 & 14.1 & 14.3 & $14.2 \pm 0.2$ & $14.1 \pm 0.2$ & 14.1 & $14.1 \pm 0.2$ & $14.1 \pm 0.2$ & $14.0 \pm 0.1$ & $14.1 \pm 0.1$ & $14.0 \pm 0.1$ & 14.1 & 14.0 \\
\hline $\mathrm{FeO}^{*}$ & 11.6 & 11.3 & 12.1 & 12.1 & $12.1 \pm 0.2$ & $12.0 \pm 0.1$ & 11.9 & $12.1 \pm 0.2$ & $12.2 \pm 0.1$ & $12.3 \pm 0.1$ & $12.3 \pm 0.1$ & $12.4 \pm 0.2$ & 13.1 & 12.9 \\
\hline $\mathrm{MgO}$ & 7.41 & 7.19 & 7.10 & 6.98 & $6.95+0.08$ & $6.85+0.06$ & 6.78 & $6.81+0.16$ & $6.84 \pm 0.10$ & $6.75 \pm 0.10$ & $6.76 \pm 0.06$ & $6.78 \pm 0.05$ & 6.62 & 6.26 \\
\hline $\mathrm{CaO}$ & 11.9 & 12.4 & 11.4 & 11.7 & $11.3 \pm 0.3$ & $11.8 \pm 0.3$ & 11.1 & $11.3 \pm 0.3$ & $11.2 \pm 0.3$ & $11.2 \pm 0.3$ & $11.3 \pm 0.2$ & $11.4 \pm 0.2$ & 11.5 & 11.0 \\
\hline $\mathrm{Na}_{2} \mathrm{O}$ & 2.53 & 2.58 & 2.61 & 2.45 & $2.59 \pm 0.08$ & $2.48 \pm 0.11$ & 2.71 & $2.64 \pm 0.08$ & $2.58 \pm 0.07$ & $2.66 \pm 0.04$ & $2.65 \pm 0.05$ & $2.50 \pm 0.05$ & 2.52 & 2.64 \\
\hline $\mathrm{K}_{2} \mathrm{O}$ & 0.09 & 0.10 & 0.15 & 0.14 & $0.15 \pm 0.01$ & $0.16 \pm 0.01$ & 0.18 & $0.15 \pm 0.01$ & $0.16 \pm 0.01$ & $0.16 \pm 0.01$ & $0.15 \pm 0.01$ & $0.16 \pm 0.00$ & 0.14 & 0.19 \\
\hline $\mathrm{TiO}_{2}$ & 1.78 & 1.77 & 1.92 & 1.90 & $1.88 \pm 0.05$ & $1.89 \pm 0.04$ & 1.88 & $1.89 \pm 0.05$ & $1.90 \pm 0.02$ & $1.92 \pm 0.01$ & $1.92 \pm 0.02$ & $1.98 \pm 0.04$ & 2.14 & 2.14 \\
\hline $\mathrm{P}_{2} \mathrm{O}_{5}$ & 0.14 & 0.17 & 0.18 & 0.16 & $0.17 \pm 0.01$ & $0.18 \pm 0.01$ & 0.22 & $0.18 \pm 0.01$ & $0.17 \pm 0.01$ & $0.18 \pm 0.02$ & $0.17 \pm 0.01$ & $0.18 \pm 0.02$ & 0.18 & 0.27 \\
\hline $\mathrm{MnO}$ & 0.17 & 0.17 & 0.19 & 0.18 & $0.18 \pm 0.01$ & $0.18 \pm 0.01$ & 0.18 & $0.18 \pm 0.01$ & $0.18 \pm 0.01$ & $0.18 \pm 0.01$ & $0.19 \pm 0.01$ & $0.19 \pm 0.01$ & 0.19 & 0.19 \\
\hline $\mathrm{SO}_{3}$ & 0.14 & 0.14 & 0.16 & 0.16 & $0.15 \pm 0.01$ & $0.15 \pm 0.01$ & 0.14 & $0.15 \pm 0.01$ & $0.15 \pm 0.01$ & $0.15 \pm 0.01$ & $0.15 \pm 0.01$ & $0.15 \pm 0.01$ & 0.18 & 0.15 \\
\hline Total & 101.0 & 100.7 & 100.7 & 100.9 & 100.2 & 100.5 & 100.4 & 100.0 & 100.0 & 100.2 & 100.2 & 100.7 & 101.4 & 100.4 \\
\hline $\mathrm{Mg} \#+$ & 55.90 & 55.67 & 53.86 & 53.37 & 53.25 & 53.05 & 52.96 & 52.66 & 52.70 & 52.11 & 52.08 & 52.10 & 50.02 & 49.07 \\
\hline $\mathrm{FeO} / \mathrm{MgO} \ddagger$ & 1.40 & 1.42 & 1.53 & 1.56 & 1.57 & 1.58 & 1.58 & 1.60 & 1.60 & 1.64 & 1.64 & 1.64 & 1.78 & 1.85 \\
\hline
\end{tabular}

Glasses were analyzed for major and minor elements with a three-channel ARL-EMX electron microprobe using U.S. Geological Survey standards of A-99 for Ti, Na, Si, and Fe; VG-2 and Indian Ocean glass 113716 for Al, $\mathrm{Ca}$, and $\mathrm{Mg}$; K-spar 2 for $\mathrm{K}$; apatite for P; pyrrhotite for S; and fayalite for Mn. Sample current was $15 \mathrm{nA}$ and counting time was $60 \mathrm{~s}$. Six or more were analyzed and averaged to give a representative value for the sample. Matrix corrections were made using a Fram 72 program [Beeson, 1967].

$\uparrow \mathrm{Mg} \#$ is the atomic proportion $(\mathrm{Mg} / \mathrm{Mg}+\mathrm{Fe})$.

$\dagger \mathrm{MgO} \#$ is the atomic
$\ddagger 0.9 \times \mathrm{FeO}^{*}$. 
TABLE 2. Representative XRF Major and Trace Element Analyses of Host Lava

\begin{tabular}{|c|c|c|c|c|c|c|c|c|c|c|c|c|c|c|c|c|}
\hline & \multicolumn{16}{|c|}{ Sample } \\
\hline & $8-2$ & $3-6$ & $12-3$ & $4-28$ & $11-0$ & $3-3$ & $4-23$ & $16-8$ & $5-7$ & $17-1$ & $26-1$ & $23-1$ & $22-17$ & $5-67$ & $16-6$ & $13-0$ \\
\hline Location & wall & wall & valley & valley & valley? & wall & valley & valley & valley & valley & valley & valley & valley & valley & wall? & wall \\
\hline $\begin{array}{l}\mathrm{SiO}_{2} \\
\mathrm{Al}_{2} \mathrm{O}_{3} \\
\mathrm{Fe}_{2} \mathrm{O}_{3} \\
\mathrm{MgO} \\
\mathrm{CaO} \\
\mathrm{Na}_{2} \mathrm{O} \\
\mathrm{K}_{2} \mathrm{O} \\
\mathrm{TiO}_{2} \\
\mathrm{P}_{2} \mathrm{O}_{5} \\
\mathrm{MnO}\end{array}$ & $\begin{array}{c}49.4 \\
14.5 \\
11.6 \\
8.01 \\
11.9 \\
2.35 \\
0.11 \\
1.50 \\
0.13 \\
0.21\end{array}$ & $\begin{array}{c}49.5 \\
13.9 \\
12.5 \\
7.45 \\
11.7 \\
2.31 \\
0.12 \\
1.69 \\
0.15 \\
0.20\end{array}$ & $\begin{array}{c}49.5 \\
13.7 \\
12.9 \\
7.09 \\
11.3 \\
2.38 \\
0.17 \\
1.84 \\
0.17 \\
0.21\end{array}$ & $\begin{array}{c}49.9 \\
13.7 \\
12.9 \\
7.00 \\
11.2 \\
2.50 \\
0.17 \\
1.79 \\
0.18 \\
0.21\end{array}$ & $\begin{array}{c}49.6 \\
13.7 \\
13.1 \\
6.98 \\
11.1 \\
2.47 \\
0.17 \\
1.84 \\
0.17 \\
0.22\end{array}$ & $\begin{array}{c}50.1 \\
13.6 \\
13.2 \\
6.89 \\
11.2 \\
2.51 \\
0.18 \\
1.84 \\
0.18 \\
0.21\end{array}$ & $\begin{array}{c}49.9 \\
13.6 \\
13.3 \\
6.94 \\
11.1 \\
2.47 \\
0.18 \\
1.87 \\
0.18 \\
0.21\end{array}$ & $\begin{array}{c}49.7 \\
13.5 \\
13.3 \\
6.80 \\
11.1 \\
2.36 \\
0.18 \\
1.92 \\
0.18 \\
0.20\end{array}$ & $\begin{array}{c}50.1 \\
13.6 \\
13.5 \\
6.87 \\
11.0 \\
2.71 \\
0.18 \\
1.88 \\
0.18 \\
0.22\end{array}$ & $\begin{array}{c}49.7 \\
13.6 \\
13.3 \\
6.78 \\
11.0 \\
2.60 \\
0.17 \\
1.87 \\
0.18 \\
0.21\end{array}$ & $\begin{array}{c}50.0 \\
13.7 \\
13.4 \\
6.78 \\
11.0 \\
2.53 \\
0.18 \\
1.88 \\
0.17 \\
0.21\end{array}$ & $\begin{array}{c}50.0 \\
13.7 \\
13.5 \\
6.80 \\
11.1 \\
2.58 \\
0.18 \\
1.88 \\
0.19 \\
0.22\end{array}$ & $\begin{array}{c}50.0 \\
13.6 \\
13.4 \\
6.77 \\
11.0 \\
2.57 \\
0.18 \\
1.88 \\
0.19 \\
0.21\end{array}$ & $\begin{array}{c}49.7 \\
13.7 \\
13.4 \\
6.74 \\
11.0 \\
2.69 \\
0.18 \\
1.89 \\
0.18 \\
0.21\end{array}$ & $\begin{array}{c}49.7 \\
13.4 \\
14.0 \\
6.58 \\
11.1 \\
2.44 \\
0.17 \\
2.06 \\
0.20 \\
0.22\end{array}$ & $\begin{array}{c}49.9 \\
13.5 \\
13.8 \\
6.32 \\
10.7 \\
2.56 \\
0.21 \\
2.11 \\
0.26 \\
0.23\end{array}$ \\
\hline Total & 99.7 & 99.5 & 99.3 & 99.6 & 99.4 & 99.9 & 99.8 & 99.2 & 100.2 & 99.4 & 99.9 & 100.2 & 99.8 & 99.7 & 99.9 & 99.6 \\
\hline $\begin{array}{l}\mathrm{Mg} \mathrm{\#} \dagger \\
\text { calculated } \mathrm{FeO} \ddagger \\
\mathrm{FeO} / \mathrm{MgO}\end{array}$ & $\begin{array}{c}60.4 \\
9.36 \\
1.17\end{array}$ & $\begin{array}{l}56.7 \\
10.2 \\
1.37\end{array}$ & $\begin{array}{c}54.8 \\
10.4 \\
1.47\end{array}$ & $\begin{array}{c}54.5 \\
10.4 \\
1.49\end{array}$ & $\begin{array}{c}53.9 \\
10.6 \\
1.52\end{array}$ & $\begin{array}{l}53.5 \\
10.7 \\
1.55\end{array}$ & $\begin{array}{c}53.5 \\
10.8 \\
1.56\end{array}$ & $\begin{array}{c}53.0 \\
10.8 \\
1.59\end{array}$ & $\begin{array}{c}52.9 \\
10.9 \\
1.59\end{array}$ & $\begin{array}{c}52.8 \\
10.8 \\
1.59\end{array}$ & $\begin{array}{c}52.7 \\
10.8 \\
1.59\end{array}$ & $\begin{array}{c}52.5 \\
10.9 \\
1.60\end{array}$ & $\begin{array}{c}52.7 \\
10.9 \\
1.61\end{array}$ & $\begin{array}{c}52.5 \\
10.9 \\
1.62\end{array}$ & $\begin{array}{c}50.8 \\
11.4 \\
1.73\end{array}$ & $\begin{array}{c}50.3 \\
11.2 \\
1.77\end{array}$ \\
\hline $\begin{array}{l}\mathrm{V} \\
\mathrm{Cr} \\
\mathrm{Ni} \\
\mathrm{Zn} \\
\mathrm{Ga} \\
\mathrm{Rb} \\
\mathrm{Sr} \\
\mathrm{Y} \\
\mathrm{Zr} \\
\mathrm{Nb}\end{array}$ & $\begin{array}{r}308 . \\
331 . \\
99 . \\
100 . \\
17.7 \\
0.9 \\
104.4 \\
32.1 \\
96.9 \\
2.9\end{array}$ & $\begin{array}{r}345 . \\
209 . \\
69 . \\
117 . \\
18.9 \\
0.8 \\
87.4 \\
36.5 \\
111 . \\
4.1\end{array}$ & $\begin{array}{r}373 . \\
169 . \\
60 . \\
115 . \\
19.0 \\
1.6 \\
103.5 \\
39.9 \\
125 . \\
5.9\end{array}$ & $\begin{array}{r}368 . \\
100 . \\
57 . \\
128 . \\
18.4 \\
1.7 \\
112.4 \\
38.6 \\
123 . \\
5.3\end{array}$ & $\begin{array}{r}375 . \\
97 . \\
56 . \\
119 . \\
18.6 \\
1.6 \\
109.9 \\
39.3 \\
128 . \\
5.3\end{array}$ & $\begin{array}{r}387 . \\
124 . \\
53 . \\
132 . \\
18.8 \\
1.4 \\
109.8 \\
39.1 \\
130 . \\
5.0\end{array}$ & $\begin{array}{c}365 . \\
94.8 \\
56 . \\
118 . \\
18.4 \\
2.0 \\
109.8 \\
40.6 \\
133 . \\
5.5\end{array}$ & $\begin{array}{r}399 . \\
108 . \\
54 . \\
121 . \\
18.8 \\
1.9 \\
114.0 \\
40.8 \\
134 . \\
6.2\end{array}$ & $\begin{array}{c}361 . \\
92.3 \\
49 . \\
119 . \\
20.5 \\
1.4 \\
115.5 \\
40.2 \\
131 . \\
5.5\end{array}$ & $\begin{array}{c}372 . \\
90.1 \\
52 . \\
119 . \\
18.6 \\
1.8 \\
114.1 \\
39.3 \\
128 . \\
5.7\end{array}$ & $\begin{array}{c}369 . \\
86.2 \\
50 . \\
120 . \\
18.5 \\
1.4 \\
113.7 \\
39.8 \\
130 . \\
5.5\end{array}$ & $\begin{array}{c}365 . \\
88.5 \\
54 . \\
117 . \\
19.5 \\
1.2 \\
114.4 \\
39.9 \\
128 . \\
5.4\end{array}$ & $\begin{array}{c}364 . \\
86.0 \\
50 . \\
119 . \\
19.6 \\
1.7 \\
114.2 \\
40.7 \\
133 . \\
5.2\end{array}$ & $\begin{array}{c}368 . \\
89.4 \\
50 . \\
121 . \\
18.9 \\
2.1 \\
114.3 \\
40.8 \\
132 . \\
5.5\end{array}$ & $\begin{array}{c}398 . \\
95.7 \\
51 . \\
127 . \\
19.1 \\
1.3 \\
99.2 \\
44.7 \\
139 . \\
4.8\end{array}$ & $\begin{array}{r}378 . \\
112 . \\
49 . \\
131 . \\
20.3 \\
2.4 \\
109.3 \\
53.3 \\
187 . \\
6.4\end{array}$ \\
\hline $\begin{array}{l}\mathrm{Zr} / \mathrm{Nb} \\
\mathrm{Zr} / \mathrm{Y} \\
\mathrm{Y} / \mathrm{Nb}\end{array}$ & $\begin{array}{l}33 \\
3.02 \\
11.1\end{array}$ & $\begin{array}{l}27 \\
3.04 \\
8.90\end{array}$ & $\begin{array}{l}21 \\
3.13 \\
6.76\end{array}$ & $\begin{array}{r}24 \\
3.26 \\
7.28\end{array}$ & $\begin{array}{r}24 \\
3.26 \\
7.42\end{array}$ & $\begin{array}{l}26 \\
3.32 \\
7.82\end{array}$ & $\begin{array}{r}24 \\
3.28 \\
7.38\end{array}$ & $\begin{array}{l}22 \\
3.28 \\
6.58\end{array}$ & $\begin{array}{r}24 \\
3.26 \\
7.31\end{array}$ & $\begin{array}{l}23 \\
3.26 \\
6.89\end{array}$ & $\begin{array}{l}24 \\
3.27 \\
7.24\end{array}$ & $\begin{array}{l}24 \\
3.21 \\
7.39\end{array}$ & $\begin{array}{l}26 . \\
3.27 \\
7.83\end{array}$ & $\begin{array}{r}24 . \\
3.24 \\
7.42\end{array}$ & $\begin{array}{l}29 . \\
3.11 \\
9.31\end{array}$ & $\begin{array}{l}29 . \\
3.51 \\
8.33\end{array}$ \\
\hline
\end{tabular}

Major element data of fresh microcrystalline samples were obtained by $\mathrm{X}$ ray fluorescence analysis (XRF) of fused glass discs, prepared by fusing the sample with a lanthanum-bearing lithium borate fusion mixture at the University of Massachusetts, Ronald $\mathrm{B}$. Gilmore Memorial Laboratory. Trace elements ( $\mathrm{TiO}_{2}, \mathrm{~V}, \mathrm{Cr}, \mathrm{Ni}, \mathrm{Zn}, \mathrm{Ga}, \mathrm{Rb}, \mathrm{Sr}, \mathrm{Y}, \mathrm{Zr}$, and $\mathrm{Nb}$ ) were determined by $\mathrm{XRF}$ analyses on pressed powder pellets. Detection limits and precision (in ppm) for the trace element analyses are 0.7 and 0.5 for $\mathrm{Nb}, 0.7$ and 1 for $\mathrm{Zr}, 0.5$ and 2 for $\mathrm{Sr}, 3$ and 1 for $\mathrm{Zn}, 3$ and 3 for $\mathrm{Ni}, 3$ and 5 for $\mathrm{Cr}, 4$ and 5 for $\mathrm{V}$, and 0.005 and 0.02 (wt \%) for $\mathrm{TiO}_{2}$

$\dagger \mathrm{Mg} \#$ = atomic proportion $\mathrm{Mg} /(\mathrm{Mg}+\mathrm{Fe})$

$\ddagger$ Calculated $\mathrm{FeO}=\left(0.9 \mathrm{FeO}^{*}\right)$. 


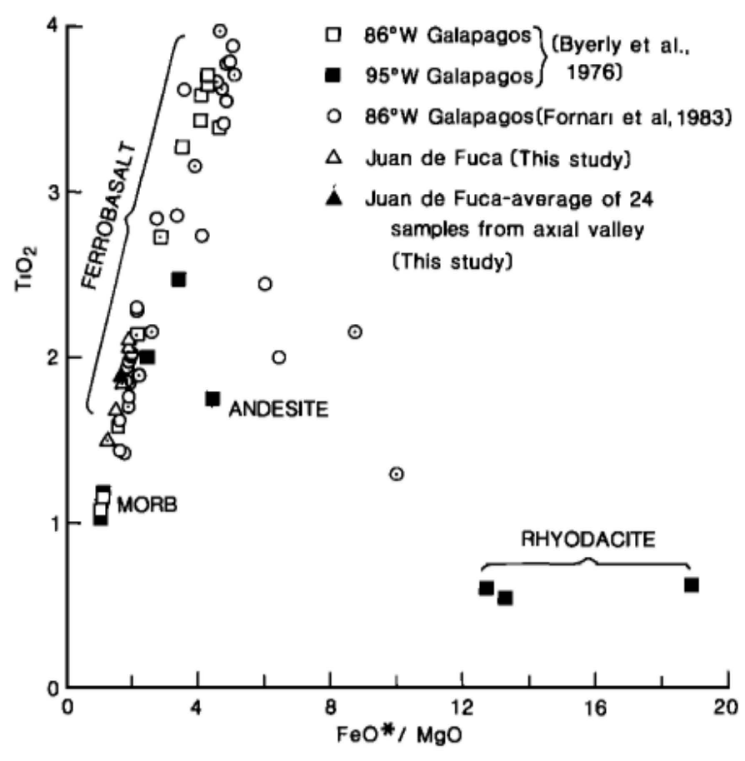

Fig. $4 a$

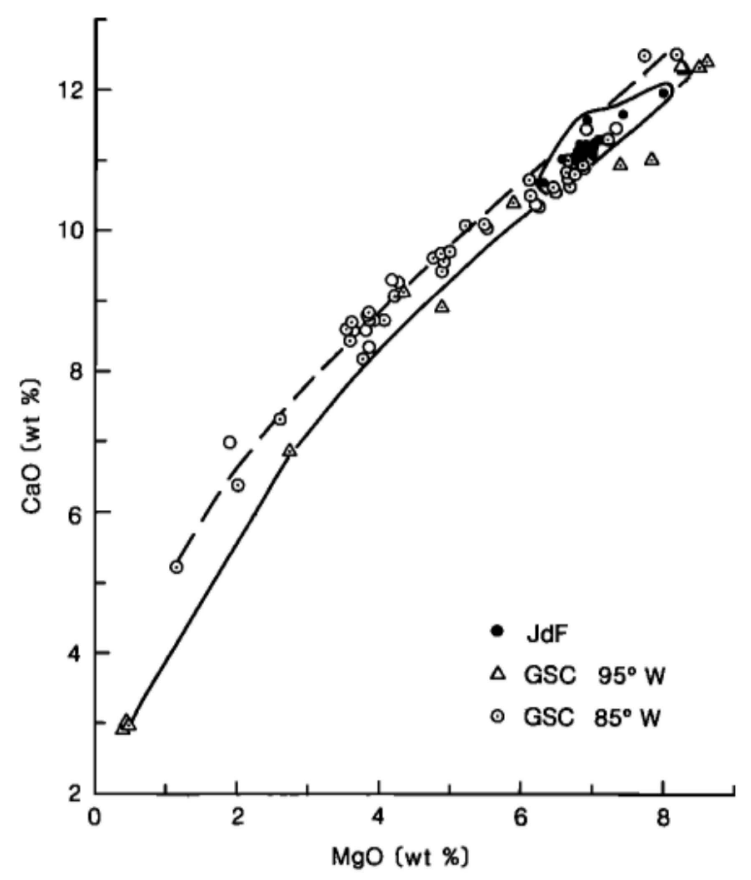

Fig. $4 b$

Fig. 4. Variation diagrams for major and minor element compositions of host lava from the southern Juan de Fuca Ridge. Data from the Galapagos spreading center (GSC) are included for comparison. (a) Plot of $\mathrm{TiO}_{2}$ versus $\mathrm{FeO} / \mathrm{MgO}^{*}$ shows the narrow range in composition at the lower end of the ferrobasalt field of the Juan de Fuca Ridge basalt data from this study superposed on the wide range in compositions from the Galapagos spreading center differentiation suite [Byerly et al., 1976; Fornari et al., 1983]. (b) Plot of $\mathrm{CaO}$ versus $\mathrm{MgO}$ shows the trend of decreasing $\mathrm{CaO}$ with decreasing $\mathrm{MgO}$ due to crystallization of olivine, clinopyroxene, and plagioclase. Juan de Fuca Ridge data from this study exhibit the same trends as the Galapagos spreading center data [Clague et al., 1981; Fornari et al., 1983] but are more limited in extent of differentiation. (c) Plot of $\mathrm{P}_{2} \mathrm{O}_{5}$ versus $\mathrm{K}_{2} \mathrm{O}$ for Juan de Fuca Ridge data from this study compared to Galapagos spreading center data [Clague et al., 1981]. The ratio of two incompatible elements should be indicative of the source regions. Data from Galapagos spreading center at $85^{\circ} \mathrm{W}$, Galapagos spreading center at $95^{\circ} \mathrm{W}$, and Juan de Fuca Ridge (this study) define linear but distinct trends suggesting differences in the source regions. Data from the axial valley form a tight cluster in Figures $4 b$ and $4 c$. Data from the valley walls are more scattered.

from the Galapagos spreading center. Galapagos spreading center lavas from near $95^{\circ} \mathrm{W}$ and $86^{\circ} \mathrm{W}$ exhibit decreasing $\mathrm{P}_{2} \mathrm{O}_{5}, \mathrm{TiO}_{2}, \mathrm{~V}$, and $\mathrm{Zn}$ contents at very high $\mathrm{FeO}^{*} / \mathrm{MgO}$ ratios; these trends are consistent with late stage fractionation of apatite and titanomagnetite. Lavas from the southern Juan

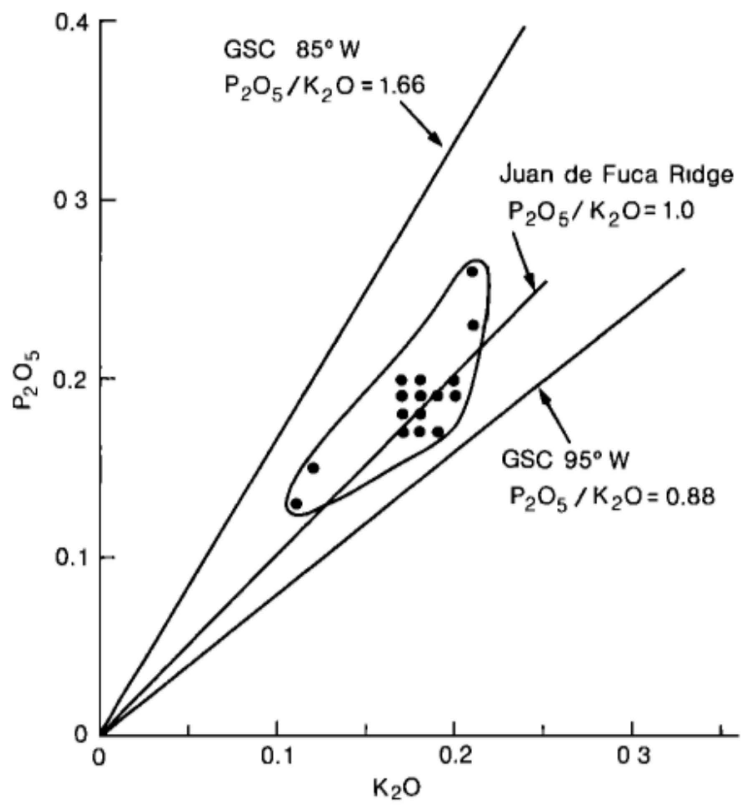

Fig. $4 c$ de Fuca Ridge are more fractionated than normal MORB but show a more restricted compositional range than lavas from the Galapagos spreading center and do not appear to have reached saturation with titanomagnetite or apatite.

These major element trends for the Juan de Fuca samples can be modeled by fractionation of plagioclase, clinopyroxene, and lesser olivine as described by Clague and Bunch [1976]. Fractionation, however, may not be a unique solution. Mixing of relatively primitive magmas with extremely evolved magmas residing in the subaxial chamber can produce nearly identical major element geochemical trends. The role of mixing will be developed later in the paper.

The $\mathrm{Sr}$ isotopic data [Eaby et al., 1984] and the trace and minor element ratios discussed above indicate that these lavas from the southern Juan de Fuca Ridge are derived from a relatively depleted source region. Several other samples from this section of the ridge have rare earth patterns that are depleted in light rare earth elements, as one might expect based on the other trace element and isotopic data. These samples have chondrite-normalized $\mathrm{La} / \mathrm{Sm}$ of $0.67-0.75$ [Schilling et al., 1982], similar to the $95^{\circ} \mathrm{W}$ Galapagos spreading center source which has chondrite-normalized $\mathrm{La} / \mathrm{Sm}=0.67$ [Clague et al., 1981] and ${ }^{87} \mathrm{Sr} /{ }^{86} \mathrm{Sr}$ ratios of approximately $0.7027-0.7028$ [Verma and Schilling, 1982]. In contrast, the source region beneath $85^{\circ} \mathrm{W}$ on the Galapagos spreading center has chondrite-normalized $\mathrm{La} / \mathrm{Sm}=0.46$ and ${ }^{87} \mathrm{Sr} /{ }^{86} \mathrm{Sr}=0.7024-0.7025$. We conclude that the source region beneath this section of the southern Juan de Fuca Ridge is comparably depleted to that at $95^{\circ} \mathrm{W}$ but is far less 

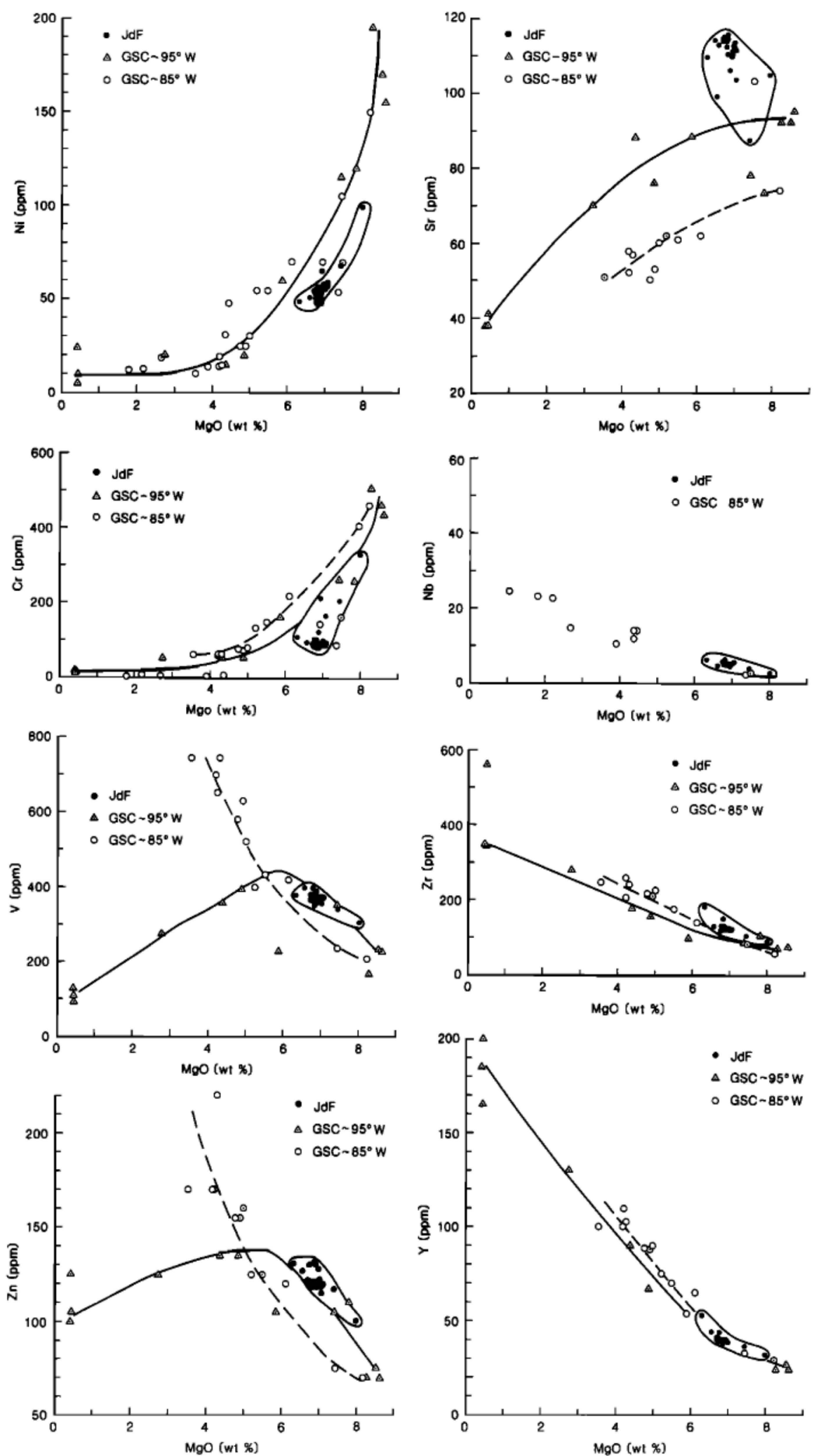

Fig. 5. Trace element content as a function of $\mathrm{MgO}$ content for lava from the southern Juan de Fuca Ridge compared to data from the Galapagos spreading center [Clague et al., 1981; Perfit et al., 1983]. Lines are drawn by eye. Trace element contents of samples from the axial valley form a tight cluster, while trace element contents of samples from the axial walls define the extremes of the enclosed fields.

depleted than that at $85^{\circ} \mathrm{W}$ on the Galapagos spreading center. The source regions underlying the Juan de Fuca Ridge and near $95^{\circ} \mathrm{W}$ on the Galapagos spreading center, although comparably depleted in terms of $\mathrm{La} / \mathrm{Sm}$ and ${ }^{87} \mathrm{Sr} /{ }^{86} \mathrm{Sr}$, are not identical in that Juan de Fuca Ridge source has higher abundances of $\mathrm{Sr}$ and $\mathrm{Na}$.

Differences in trace element ratios [Clague et al., 1981; LeRoex et al., 1983] for the axial valley and axial valley wall 
samples indicate that the older valley wall lavas were derived from a more depleted source than the younger valley floor lavas. This observation suggests that the source regions for Juan de Fuca MORB may be heterogeneous on a time scale of thousands to tens of thousands of years.

\section{XeNOLITHS}

Xenoliths comprise $\ll 1 \%$ of the dredge contents. They range in size from $1 \mathrm{~cm}^{3}$ (glomerocryst) to $240 \mathrm{~cm}^{3}$ (Figures $7 a$ and $7 b$ ). Xenoliths commonly occur near the upper glassy selvage and along fractures of the sheet and lobate flow fragments. The common occurrence of xenoliths on fracture surfaces suggests that a mechanism such as differential contraction during cooling between the host lava and the xenolith created strain that induced fracturing.

On the basis of texture and mineralogy, xenoliths have been subdivided into three types: type I: medium-grained; plagioclase + olivine + glass; type II: medium-grained; plagioclase + augite \pm olivine + glass; and type III: medium- to coarse-grained; $\quad$ plagioclase + augite + olivine \pm inverted pigeonite $\pm \mathrm{Fe}$-Ti oxides + glass. All xenoliths have small volumes $(<1 \%)$ of sulfide globules.

The following sections describe the textures and phase chemistry of each xenolith type. Compositions of plagioclase, olivine, pyroxene, oxides, and interstitial glass are given in Tables 3, 4, 5, 6, and 7 and shown in Figure 6, 8, and 10. Glass inclusion data (Tables 8 and 9 and Figure 11) will be discussed separately. Modal compositions of xenoliths are shown in Table 10.

\section{Type I Xenoliths}

Three small $\left(<1 \mathrm{~cm}^{3}\right)$ olivine plus plagioclase xenoliths were found. Xenoliths 5-17, 17-7, and 17-12 are open-textured, medium-grained hypidiomorphic interstitial gabbros. Type I xenoliths are a loose cluster of crystals with olivine (up to 3 $\mathrm{mm}$ in length) subophitically enclosing or interstitial to euhedral plagioclase (up to $3 \mathrm{~mm}$ ). Mineral grains are fresh and have not reacted with the surrounding melt. A rim of variolitic cystallization formed upon quenching around plagioclase.

Plagioclase occurs as weakly zoned laths having the same compositional range as the microphenocrysts in the lavas. The compositional range in sample 17-12 is $\mathrm{An}_{68}$ to $\mathrm{An}_{73}$ and in sample 5-17 is $A n_{65}$ to $A n_{73}$. The average composition of 24 analyses is $\mathrm{An}_{72.8}$, slightly more sodic than the average microphenocryst composition.

Olivine compositions within each sample are homogeneous; the range of olivine compositions in sample 17-7 is $\mathrm{Fo}_{78.1}$ to $\mathrm{Fo}_{78.8}$ and in sample 17-12 is $\mathrm{Fo}_{785}$ to $\mathrm{Fo}_{78}$. These compositions are intermediate between compositions of microphenocrysts and olivine in xenolith types II and III. The range of compositions in sample 5-17 is $\mathrm{Fo}_{71.5}$ to $\mathrm{Fo}_{72 \mathrm{~s}}$, which are more like those for olivine in type II xenoliths. NiO contents in type I olivine were not analyzed.

Interstitial glass ( $25-30$ modal $\%$ ) is compositionally similar to the surrounding host glass. $\mathrm{FeO} / \mathrm{MgO}$ (using $\mathrm{FeO}$ $\left.=\mathrm{FeO}^{*} \times 0.9\right)$ is 1.62 for the interstitial glass similar to 1.60 for the host lava. Interstitial glass contains $1.92 \mathrm{wt} \% \mathrm{TiO}_{2}$, 2.58 wt $\% \mathrm{Na}_{2} \mathrm{O}$, and 0.18 wt $\% \mathrm{P}_{2} \mathrm{O}_{5}$.

\section{Type II Xenoliths}

Type II xenoliths are composed dominantly of plagioclase, augite, and glass. Minor volumes of olivine are present. Samples $17-1$ and 5-0 (Figure $7 a$ ) are representative of type II xenoliths and are described in detail below.

Sample 17-1, the largest open-textured xenolith $\left(240 \mathrm{~cm}^{3}\right)$, forms a toe of a sheet flow fragment and is texturally similar to glassy, highly porphyritic lava (Figure 7c). Euhedral to subhedral augite, and rarely olivine, poikilitically enclose the plagioclase laths to form subophitic clusters. Abundant glass inclusions indicate rapid crystal growth. Glass adjacent to plagioclase and augite is opaque brown due to variolitic crystallization. Interstitial glass comprises 50 modal \% of the xenolith and is pale translucent brown away from the crystal grain boundaries. Flow of melt around crystals is indicated by variations in color and incipient crystallization (Figure $7 d$ ). The absence of embayed crystals or mineral zonation suggests that glass and minerals have not reacted.

Sample 5-0 is a medium to coarse grained hypidiomorphic granular gabbro (Figure 7e). Euhedral plagioclase laths are similar in size and morphology to those in 17-1 but exhibit slight zoning. Augite oikocrysts are up to $1 \mathrm{~cm}$ across. Interstitial glass ( 22 modal \%) is opaque due to incipient crystallization. There is no evidence of interaction between xenolith minerals and the surrounding lava; mineral-glass interfaces are sharp with euhedral crystal forms.

The majority of the type II xenoliths consist of subophitic to interstitial clusters of plagioclase + augite + glass, smaller than $\left(<1 \mathrm{~cm}^{3}\right)$ but similar to xenolith 5-0. Rare inclusions of olivine in augite and vice versa occur, but generally these phases are not intergrown.

Plagioclase laths in type II xenoliths range in composition from $\mathrm{An}_{6.15}$ to $A \mathrm{n}_{74} \mathrm{o}$ and have an average composition of $\mathrm{An}_{68.6}$. Plagioclase in open-textured xenoliths (i.e., 17-1) is weakly zoned and shows little variation within a single xenolith. Plagioclase compositions from more crystalline xenoliths have slight normal oscillatory zoning. Early formed plagioclase laths, which are poikilitically enclosed by augite, tend to be more Ca-rich than small tabular grains growing adjacent to interstitital glass or at the xenolith-host lava boundary.

Olivine in type II xenoliths occurs as small discrete grains at the edge of the xenolith in samples 5-0 and 5-77 or as subhedral to anhedral grains subophitically enclosing small euhedral plagioclase laths in sample 5-1. These olivine grains are unzoned and range in composition from $\mathrm{Fo}_{72}$ to $\mathrm{Fo}_{73} 2$.

Pyroxene in type II xenoliths occurs as homogeneous oikocrysts and more rarely as small discrete grains in the interstitital glass. The dominant compositional trend is one of decreasing $\mathrm{Mg}, \mathrm{Ca}$, and $\mathrm{Cr}$ and increasing $\mathrm{Ti}$ with increasing $\mathrm{Fe}$ content. Oikocrysts range in composition from $\mathrm{Wo}_{41.5} \mathrm{Fs}_{8.8} \mathrm{En}_{49,7}$ (sample 4-7) to $\mathrm{Wo}_{40.0} \mathrm{Fs}_{12.3} \mathrm{En}_{47.7}$ (sample 17-65). Analyses 11 and 14 in Table 5 are typical of most of the oikocrysts. An Fe-enrichment trend is also observed between oikocrysts and small augite grains in the interstitial glass or near the xenolith-host lava boundary. Analyses of pyroxenes from sample 5-1 (analyses 12 and 13 in Table 5) show that the oikocryst has $100 \times \mathrm{Fe} /(\mathrm{Fe}+\mathrm{Mg}$ ) ratio of 15.9 , while a small grain in the interstitial glass has a ratio of 21.5 . The more differentiated composition of late forming pyroxene is also observed in samples 5-0 and 5-13.

Interstitial glass compositions in type II xenoliths define Fe-enrichment trends with increased crystallinity of the xenoliths. Compositions range from similar to the host lava $\left(\mathrm{FeO} / \mathrm{MgO}\right.$ (using $\left.\mathrm{FeO}=\mathrm{FeO}^{*} \times 0.9\right)$ ratio is 1.67 ) to more differentiated than the host lava $(\mathrm{FeO} / \mathrm{MgO}$ ratio is 2.59$)$. $\mathrm{TiO}_{2}$ content ranges from 1.90 to 2.65 wt \%. $\mathrm{Na}_{2} \mathrm{O}$ content ranges from 2.67 to $3.28 \mathrm{wt} \% . \mathrm{P}_{2} \mathrm{O}_{5}$ content ranges from 0.20 to $0.33 \mathrm{wt} \% . \mathrm{K}_{2} \mathrm{O}$ content ranges from 0.18 to $0.33 \mathrm{wt} \%$. Chemical variation trends defined by the interstitial glass are similar to trends observed in the host glass but extend to more evolved compositions. Figures $8 a$ and $8 b$ show increasing $\mathrm{TiO}_{2}$ with decreasing $\mathrm{Mg}$ number and increasing $\mathrm{P}_{2} \mathrm{O}_{5}$ and $\mathrm{K}_{2} \mathrm{O}$ at essentially the same $\mathrm{P}_{2} \mathrm{O}_{5} / \mathrm{K}_{2} \mathrm{O}$ ratio. 


\section{Type III Xenoliths}

Type III xenoliths are generally coarser-grained, more crystalline, and mineralogically more evolved than types I and II. The most crystalline type III xenoliths are characterized by zoning in plagioclase and augite, a wide range of grain sizes, intricate intergrowth textures, and random mineral grain orientation. Type III xenoliths have reacted with the host melt more than the other xenolith types. Samples 26-1A, 5-7A, 5-7B, and 5-8B are typical of type III xenoliths (Figures $7 b, 7 f$, $7 g$, and $7 h$ ).

Sample 26-1A is a medium-grained hypidiomorphic granular intersertal gabbro. Grain sizes range from 0.1 to $6 \mathrm{~mm}$ for plagioclase, 0.3 to $3 \mathrm{~mm}$ for olivine, and 0.2 to $5 \mathrm{~mm}$ for augite. The texture is more equigranular than other type III xenoliths. Mineral grains have no preferred orientation. Plagioclase is subhedral to euhedral. Larger grains exhibit slight optical zonation. Although normal zonation is most common, rare oscillatory zonation is also present. Olivine and augite appear to have crystallized simultaneously. Crystalmesostasis interfaces are sharp.

Samples 5-7A and 5-8B are coarse-grained hypidiomorphic granular olivine gabbro. In sample 5-7A olivine is the main oikocryst phase and occurs as large (5 $\mathrm{mm}$ across), optically continuous subhedral grains. Olivine and augite subophitically enclose plagioclase but do not enclose each other. Larger plagioclase grains are subhedral because of impingement of cocrystallizing olivine. Only 1 modal $\%$ interstitial glass remains. In sample $5-8 \mathrm{~B}$, augite is the main oikocryst phase which subophitically encloses plagioclase (up to $1 \mathrm{~cm}$ in length). Augite and plagioclase exhibit intricate intergrowth textures (Figure 9a), indicating simultaneous growth. Normal and oscillatory zoning occurs in the larger plagioclase grains. In 5-7A and 5-8B the larger augite grains exhibit optical zoning. Interstitial glass comprises 3 modal \%. Augite has no exsolution lamellae of orthopyroxene, but minute exsolution

TABLE 3a. Plagioclase Anạlyses

\begin{tabular}{|c|c|c|c|c|c|c|c|c|c|c|c|c|c|c|}
\hline & \multicolumn{5}{|c|}{ Microphenocrysts } & \multicolumn{2}{|c|}{ Type I } & \multicolumn{7}{|c|}{ Type II } \\
\hline & 1 & 2 & 3 & 4 & 5 & 6 & 7 & 8 & 9 & 10 & 11 & 12 & 13 & 14 \\
\hline $\begin{array}{l}\text { Sample } \\
\text { Comment } \dagger\end{array}$ & $\begin{array}{l}4-35 \\
\max \end{array}$ & $\begin{array}{l}4-35 \\
\min \end{array}$ & $\begin{array}{c}8-2 \\
\max \end{array}$ & $\begin{array}{l}8-2 \\
\min \end{array}$ & $5-7 A$ & $\begin{array}{l}17-12 \\
\max \end{array}$ & $\begin{array}{c}17-12 \\
\min \end{array}$ & $\begin{array}{l}5-0 \\
\text { core }\end{array}$ & $\begin{array}{c}5-0 \\
\text { midway }\end{array}$ & $\begin{array}{l}5-0 \\
\text { rim }\end{array}$ & $\begin{array}{c}5-0 \\
\text { small } \\
\text { in gm }\end{array}$ & $\begin{array}{c}5-0 \\
\text { small } \\
\text { in aug }\end{array}$ & $\begin{array}{c}5-13 \\
\text { small } \\
\text { in gm }\end{array}$ & $\begin{array}{c}5-13 \\
\text { small } \\
\text { in aug }\end{array}$ \\
\hline $\begin{array}{l}\mathrm{SiO}_{2} \\
\mathrm{Al}_{2} \mathrm{O}_{3} \\
\mathrm{FeO} \\
\mathrm{CaO} \\
\mathrm{NaO} \\
\mathrm{K}_{2} \mathrm{O}\end{array}$ & $\begin{array}{c}47.6 \\
32.7 \\
0.38 \\
17.4 \\
1.79 \\
\cdots\end{array}$ & $\begin{array}{c}51.0 \\
30.6 \\
0.51 \\
14.7 \\
3.27 \\
\cdots\end{array}$ & $\begin{array}{c}49.4 \\
31.6 \\
0.43 \\
16.0 \\
2.57 \\
\cdots\end{array}$ & $\begin{array}{c}51.9 \\
29.0 \\
0.48 \\
14.5 \\
3.43 \\
\cdots\end{array}$ & $\begin{array}{c}50.0 \\
31.3 \\
0.52 \\
14.9 \\
3.11 \\
0.04\end{array}$ & $\begin{array}{c}47.4 \\
32.8 \\
0.44 \\
17.9 \\
1.60 \\
\cdots\end{array}$ & $\begin{array}{c}51.1 \\
30.4 \\
0.49 \\
13.9 \\
3.68 \\
\cdots\end{array}$ & $\begin{array}{c}50.8 \\
31.1 \\
0.41 \\
14.2 \\
3.55 \\
0.03\end{array}$ & $\begin{array}{c}50.8 \\
30.9 \\
0.52 \\
14.0 \\
3.66 \\
0.02\end{array}$ & $\begin{array}{c}51.0 \\
31.2 \\
0.65 \\
14.3 \\
3.56 \\
0.04\end{array}$ & $\begin{array}{c}51.5 \\
30.4 \\
0.54 \\
13.6 \\
3.91 \\
0.03\end{array}$ & $\begin{array}{c}50.4 \\
31.1 \\
0.53 \\
14.4 \\
3.41 \\
0.04\end{array}$ & $\begin{array}{c}49.4 \\
30.7 \\
0.75 \\
14.5 \\
3.24 \\
0.02\end{array}$ & $\begin{array}{c}50.2 \\
30.5 \\
0.61 \\
13.9 \\
3.40 \\
0.04\end{array}$ \\
\hline Total & 100.9 & 100.2 & 100.0 & 100.3 & 99.9 & 100.2 & 99.6 & 100.1 & 99.9 & 100.8 & 100.0 & 99.9 & 98.6 & 98.6 \\
\hline $\begin{array}{l}\mathrm{Si} \\
\mathrm{Al} \\
\mathrm{Fe} \\
\mathrm{Ca} \\
\mathrm{Na} \\
\mathrm{K}\end{array}$ & $\begin{array}{l}2.192 \\
1.777 \\
0.014 \\
0.858 \\
0.160 \\
\ldots\end{array}$ & $\begin{array}{l}2.326 \\
1.644 \\
0.019 \\
0.718 \\
0.290 \\
\cdots\end{array}$ & $\begin{array}{l}2.263 \\
1.707 \\
0.017 \\
0.785 \\
0.226 \\
\cdots\end{array}$ & $\begin{array}{l}2.382 \\
1.568 \\
0.019 \\
0.714 \\
0.303 \\
\cdots\end{array}$ & $\begin{array}{l}2.290 \\
1.687 \\
0.020 \\
0.731 \\
0.276 \\
0.002\end{array}$ & $\begin{array}{c}\text { ations per } \\
2.180 \\
1.779 \\
0.017 \\
0.882 \\
0.144 \\
\cdots\end{array}$ & $\begin{array}{c}\text { Formul } \\
2.340 \\
1.639 \\
0.019 \\
0.682 \\
0.324 \\
\ldots\end{array}$ & $\begin{array}{r}\text { a Unit } \\
2.316 \\
1.670 \\
0.016 \\
0.691 \\
0.313 \\
0.001\end{array}$ & $\begin{array}{l}2.321 \\
1.661 \\
0.020 \\
0.684 \\
0.324 \\
0.001\end{array}$ & $\begin{array}{l}2.312 \\
1.667 \\
0.025 \\
0.693 \\
0.313 \\
0.002\end{array}$ & $\begin{array}{l}2.348 \\
1.631 \\
0.021 \\
0.664 \\
0.346 \\
0.002\end{array}$ & $\begin{array}{l}2.302 \\
1.677 \\
0.020 \\
0.707 \\
0.303 \\
0.002\end{array}$ & $\begin{array}{l}2.293 \\
1.679 \\
0.029 \\
0.719 \\
0.292 \\
0.001\end{array}$ & $\begin{array}{l}2.322 \\
1.661 \\
0.024 \\
0.687 \\
0.305 \\
0.002\end{array}$ \\
\hline Total & 5.001 & 4.997 & 4.998 & 4.986 & 5.006 & 5.002 & 5.004 & 5.007 & 5.011 & 5.012 & 5.012 & 5.011 & 5.013 & 5.001 \\
\hline \multirow[t]{3}{*}{ An $\%$} & 84.3 & 71.2 & 77.6 & 70.2 & 72.5 & 86.0 & 67.8 & 68.8 & 67.8 & 68.8 & 65.6 & 69.9 & 71.0 & 69.1 \\
\hline & \multicolumn{14}{|c|}{ Type II } \\
\hline & 15 & 16 & 17 & 18 & 19 & 20 & 21 & 22 & 23 & 24 & 25 & 26 & 27 & 28 \\
\hline $\begin{array}{l}\text { Sample } \\
\text { Comment } \dagger\end{array}$ & $\begin{array}{c}5-77 \\
\text { large } \\
\text { in gm }\end{array}$ & $\begin{array}{c}5-77 \\
\text { small } \\
\text { in gm }\end{array}$ & $\begin{array}{l}17-1 \\
\text { large } \\
\text { in gl }\end{array}$ & $\begin{array}{l}17-1 \\
\text { small } \\
\text { in gl }\end{array}$ & $\begin{array}{c}17-1 \\
\text { large } \\
\text { in aug }\end{array}$ & $\begin{array}{l}17-1 \\
\text { small } \\
\text { in } \mathrm{gl}\end{array}$ & $\begin{array}{c}17-4 \\
\text { core } \\
\text { in aug }\end{array}$ & $\begin{array}{c}17-4 \\
\text { small } \\
\text { in aug }\end{array}$ & $\begin{array}{c}17-4 \\
\text { small } \\
\text { in aug }\end{array}$ & $\begin{array}{c}17-65 \\
\text { small } \\
\text { in aug }\end{array}$ & $\begin{array}{l}17-65 \\
\text { small } \\
\text { in gm }\end{array}$ & $\begin{array}{l}17-65 \\
\text { small } \\
\text { in aug }\end{array}$ & $\begin{array}{c}17-66 \\
\text { small } \\
\text { in gl }\end{array}$ & $\begin{array}{c}17-66 \\
\text { small } \\
\text { in } \mathrm{gl}\end{array}$ \\
\hline $\begin{array}{l}\mathrm{SiO}_{2} \\
\mathrm{Al}_{2} \mathrm{O}_{3} \\
\mathrm{FeO} \\
\mathrm{CaO} \\
\mathrm{Na}_{2} \mathrm{O} \\
\mathrm{K}_{2} \mathrm{O}\end{array}$ & $\begin{array}{c}50.7 \\
29.8 \\
0.60 \\
14.3 \\
3.25 \\
0.04\end{array}$ & $\begin{array}{c}50.4 \\
30.0 \\
0.68 \\
13.7 \\
3.57 \\
0.04\end{array}$ & $\begin{array}{c}50.6 \\
29.9 \\
0.58 \\
13.4 \\
3.67 \\
0.07\end{array}$ & $\begin{array}{c}50.1 \\
32.1 \\
0.60 \\
14.6 \\
3.19 \\
0.03\end{array}$ & $\begin{array}{c}50.4 \\
30.2 \\
0.62 \\
13.7 \\
3.65 \\
0.02\end{array}$ & $\begin{array}{c}49.9 \\
30.4 \\
0.53 \\
14.1 \\
3.38 \\
0.03\end{array}$ & $\begin{array}{c}50.1 \\
30.9 \\
0.55 \\
14.1 \\
3.35 \\
0.03\end{array}$ & $\begin{array}{c}49.5 \\
30.7 \\
0.60 \\
14.9 \\
2.98 \\
0.03\end{array}$ & $\begin{array}{c}49.1 \\
31.0 \\
0.60 \\
14.9 \\
2.87 \\
0.03\end{array}$ & $\begin{array}{c}51.3 \\
29.6 \\
0.56 \\
13.0 \\
3.95 \\
0.05\end{array}$ & $\begin{array}{c}52.3 \\
28.9 \\
0.60 \\
12.7 \\
4.34 \\
0.05\end{array}$ & $\begin{array}{c}51.5 \\
29.5 \\
0.57 \\
12.9 \\
4.14 \\
0.05\end{array}$ & $\begin{array}{c}51.2 \\
30.6 \\
0.59 \\
13.6 \\
3.58 \\
0.03\end{array}$ & $\begin{array}{c}50.5 \\
30.6 \\
0.56 \\
14.3 \\
3.30 \\
0.04\end{array}$ \\
\hline Total & 98.6 & 98.4 & 98.2 & 100.6 & 98.6 & 98.4 & 99.0 & 98.7 & 98.5 & 98.5 & 98.9 & 98.6 & 99.6 & 99.3 \\
\hline \multicolumn{15}{|c|}{ Cations per Formula Unit } \\
\hline $\begin{array}{l}\mathrm{Si} \\
\mathrm{Al} \\
\mathrm{Fe} \\
\mathrm{Ca} \\
\mathrm{Na} \\
\mathrm{K}\end{array}$ & $\begin{array}{l}2.344 \\
1.622 \\
0.023 \\
0.708 \\
0.291 \\
0.002\end{array}$ & $\begin{array}{l}2.338 \\
1.639 \\
0.027 \\
0.677 \\
0.320 \\
0.002\end{array}$ & $\begin{array}{l}2.348 \\
1.632 \\
0.023 \\
0.666 \\
0.330 \\
0.004\end{array}$ & $\begin{array}{l}2.273 \\
1.719 \\
0.023 \\
0.711 \\
0.281 \\
0.002\end{array}$ & $\begin{array}{l}2.332 \\
1.647 \\
0.024 \\
0.677 \\
0.327 \\
0.001\end{array}$ & $\begin{array}{l}2.316 \\
1.662 \\
0.020 \\
0.701 \\
0.304 \\
0.002\end{array}$ & $\begin{array}{l}2.307 \\
1.679 \\
0.021 \\
0.696 \\
0.299 \\
0.002\end{array}$ & $\begin{array}{l}2.294 \\
1.678 \\
0.023 \\
0.738 \\
0.268 \\
0.002\end{array}$ & $\begin{array}{l}2.281 \\
1.696 \\
0.023 \\
0.740 \\
0.258 \\
0.002\end{array}$ & $\begin{array}{l}2.369 \\
1.611 \\
0.022 \\
0.645 \\
0.354 \\
0.003\end{array}$ & $\begin{array}{l}2.405 \\
1.565 \\
0.023 \\
0.624 \\
0.387 \\
0.003\end{array}$ & $\begin{array}{l}2.374 \\
1.603 \\
0.022 \\
0.639 \\
0.370 \\
0.003\end{array}$ & $\begin{array}{l}2.340 \\
1.647 \\
0.022 \\
0.668 \\
0.317 \\
0.002\end{array}$ & $\begin{array}{l}2.319 \\
1.657 \\
0.022 \\
0.706 \\
0.294 \\
0.002\end{array}$ \\
\hline Total & 4.990 & 5.003 & 5.003 & 5.009 & 5.008 & 5.005 & 5.004 & 5.003 & 5.000 & 5.004 & 5.007 & 5.007 & 4.996 & 5.000 \\
\hline An $\%$ & 70.7 & 67.8 & 66.6 & 71.5 & 67.4 & 69.6 & 69.8 & 73.2 & 74.0 & 64.4 & 61.5 & 63.1 & 67.7 & 70.5 \\
\hline
\end{tabular}


TABLE 3a. (continued)

\begin{tabular}{|c|c|c|c|c|c|c|c|c|c|c|c|c|c|}
\hline & \multicolumn{13}{|c|}{ Type III } \\
\hline & 29 & 30 & 31 & 32 & 33 & 34 & 35 & 36 & 37 & 38 & 39 & 40 & 41 \\
\hline $\begin{array}{l}\text { Sample } \\
\text { Comment } \dagger\end{array}$ & $\begin{array}{l}17-66 \\
\text { small } \\
\text { in } \mathrm{gl}\end{array}$ & $\begin{array}{c}17-69 \\
\text { lg } \\
\text { in } \mathrm{gm}\end{array}$ & $\begin{array}{l}17-69 \\
\text { small } \\
\text { in gm }\end{array}$ & $\begin{array}{l}5-7 \mathrm{~A} \\
\text { core } \\
\text { large }\end{array}$ & $\begin{array}{c}\text { 5-7A } \\
\text { small } \\
\text { center }\end{array}$ & $\begin{array}{l}\text { 5-7A } \\
\text { small } \\
\text { edge }\end{array}$ & $\begin{array}{l}5-7 \mathrm{~A} \\
\text { core } \\
\text { edge }\end{array}$ & $\begin{array}{c}5-7 \mathrm{~A} \\
\text { core } \\
\text { center }\end{array}$ & $\begin{array}{c}5-8 B \\
\text { core } \\
\text { center }\end{array}$ & $\begin{array}{l}\text { 5-8B } \\
\text { rim } \\
\text { center }\end{array}$ & $\begin{array}{l}16-7 \mathrm{~A} \\
\text { small } \\
\text { in gl }\end{array}$ & $\begin{array}{c}26-1 \mathrm{~A} \\
\text { small } \\
\text { in } \mathrm{gl}\end{array}$ & $\begin{array}{c}26-1 \mathrm{~A} \\
\text { small } \\
\text { in aug }\end{array}$ \\
\hline $\begin{array}{l}\mathrm{SiO}_{2} \\
\mathrm{Al}_{2} \mathrm{O}_{3} \\
\mathrm{FeO} \\
\mathrm{CaO} \\
\mathrm{Na}_{2} \mathrm{O} \\
\mathrm{K}_{2} \mathrm{O}\end{array}$ & $\begin{array}{c}51.1 \\
30.5 \\
0.57 \\
13.9 \\
3.48 \\
0.04\end{array}$ & $\begin{array}{c}50.5 \\
30.2 \\
0.54 \\
13.9 \\
3.53 \\
0.05\end{array}$ & $\begin{array}{c}50.3 \\
30.5 \\
0.57 \\
14.2 \\
3.27 \\
0.04\end{array}$ & $\begin{array}{c}50.8 \\
30.9 \\
0.63 \\
14.3 \\
3.53 \\
0.03\end{array}$ & $\begin{array}{c}50.5 \\
31.2 \\
0.43 \\
14.4 \\
3.51 \\
0.03\end{array}$ & $\begin{array}{c}52.9 \\
28.1 \\
0.67 \\
11.8 \\
4.62 \\
0.17\end{array}$ & $\begin{array}{c}49.7 \\
30.6 \\
0.62 \\
14.1 \\
3.27 \\
0.06\end{array}$ & $\begin{array}{c}49.9 \\
30.4 \\
0.64 \\
14.0 \\
3.46 \\
0.04\end{array}$ & $\begin{array}{c}51.1 \\
30.8 \\
0.60 \\
13.9 \\
3.61 \\
0.04\end{array}$ & $\begin{array}{c}52.9 \\
29.1 \\
0.68 \\
11.9 \\
4.60 \\
0.09\end{array}$ & $\begin{array}{c}55.3 \\
27.5 \\
0.66 \\
12.1 \\
4.78 \\
0.08\end{array}$ & $\begin{array}{c}50.4 \\
29.9 \\
0.66 \\
13.2 \\
3.93 \\
0.05\end{array}$ & $\begin{array}{c}49.0 \\
31.1 \\
0.65 \\
14.4 \\
3.05 \\
0.07\end{array}$ \\
\hline Total & 99.6 & 98.7 & 98.9 & 100.2 & 100.1 & 98.3 & 98.4 & 98.4 & 100.0 & 99.3 & 100.4 & 98.1 & 98.3 \\
\hline \multicolumn{14}{|c|}{ Cations per Formula Unit } \\
\hline $\begin{array}{l}\mathrm{Si} \\
\mathrm{Al} \\
\mathrm{Fe} \\
\mathrm{Ca} \\
\mathrm{Na} \\
\mathrm{K}\end{array}$ & $\begin{array}{l}2.337 \\
1.644 \\
0.022 \\
0.683 \\
0.308 \\
0.002\end{array}$ & $\begin{array}{l}2.332 \\
1.645 \\
0.021 \\
0.688 \\
0.316 \\
0.003\end{array}$ & $\begin{array}{l}2.322 \\
1.658 \\
0.022 \\
0.700 \\
0.293 \\
0.002\end{array}$ & $\begin{array}{l}2.317 \\
1.658 \\
0.024 \\
0.699 \\
0.312 \\
0.002\end{array}$ & $\begin{array}{l}2.303 \\
1.679 \\
0.016 \\
0.702 \\
0.311 \\
0.002\end{array}$ & $\begin{array}{l}2.441 \\
1.531 \\
0.026 \\
0.585 \\
0.413 \\
0.010\end{array}$ & $\begin{array}{l}2.307 \\
1.675 \\
0.024 \\
0.701 \\
0.295 \\
0.003\end{array}$ & $\begin{array}{l}2.317 \\
1.658 \\
0.024 \\
0.699 \\
0.312 \\
0.002\end{array}$ & $\begin{array}{l}2.328 \\
1.655 \\
0.023 \\
0.679 \\
0.319 \\
0.002\end{array}$ & $\begin{array}{l}2.416 \\
1.568 \\
0.026 \\
0.583 \\
0.408 \\
0.005\end{array}$ & $\begin{array}{l}2.495 \\
1.461 \\
0.025 \\
0.583 \\
0.418 \\
0.005\end{array}$ & $\begin{array}{l}2.341 \\
1.639 \\
0.025 \\
0.655 \\
0.354 \\
0.003\end{array}$ & $\begin{array}{l}2.280 \\
1.706 \\
0.025 \\
0.716 \\
0.275 \\
0.004\end{array}$ \\
\hline Total & 4.996 & 5.005 & 4.997 & 5.012 & 5.013 & 5.006 & 5.005 & 5.012 & 5.006 & 5.006 & 4.987 & 5.017 & 5.006 \\
\hline An $\%$ & 68.8 & 68.3 & 70.5 & 69.0 & 69.2 & 58.0 & 70.2 & 69.0 & 67.9 & 58.5 & 58.0 & 64.7 & 72.0 \\
\hline
\end{tabular}

fmax, $\min$ refer to maximum and minimum An content; core, rim refer to location within large zoned grains; center, edge refer to location within xenolith; $\mathrm{gm}=$ groundmass; aug $=$ augite; $\mathrm{gl}=$ glass; large $=>4 \mathrm{~mm}$; small $=<2 \mathrm{~mm}$. Microprobe data for plagioclase were obtained using an ARL-EMX three-channel microprobe and reduced using the matrix correction program of Fram 72 [Beeson, 1967]. U.S. Geological Survey standards used in analysis of plagioclase were Amelia Albite for Na; Crystal Bay Bytownite for Al, Si, Ca; K-spar 2 for K; and Fayalite for Fe. Sample current was $15 \mathrm{nA}$ and counting time was $60 \mathrm{~s}$.

lamellae of oxides occur along grain boundaries. Partially inverted pigeonite occurs as an interstitial phase; remnant cores of pigeonite are surrounded by coalesced blebs of augite in a host of orthopyroxene. Figures $9 b, 9 c$, and $9 d$ shows the blebby exsolution texture. Anhedral titanomagnetite and ilmenite occur in the interstitial glass and as isolated interstitial phases (Figures $9 e$ and $9 f$ ). Fe-Ti oxides do not show optical exsolution.

The presence of subtle planar extinction discontinuities in olivine and melt-filled fractures that crosscut mineral grains indicates that these xenoliths have been deformed (Figures $9 g$, $9 h$, and $9 i$ ). The mesostasis-xenolith interface, along both the xenolith edge and melt-filled fractures, is more jagged indicating reaction with the melt. Plagioclase appears to have reacted with the host melt more than augite or olivine and commonly has a sawtooth appearance caused by fingers of melt intruding the plagioclase (Figure $9 h$ ).

TABLE $3 b$. Summary of Plagioclase Compositions

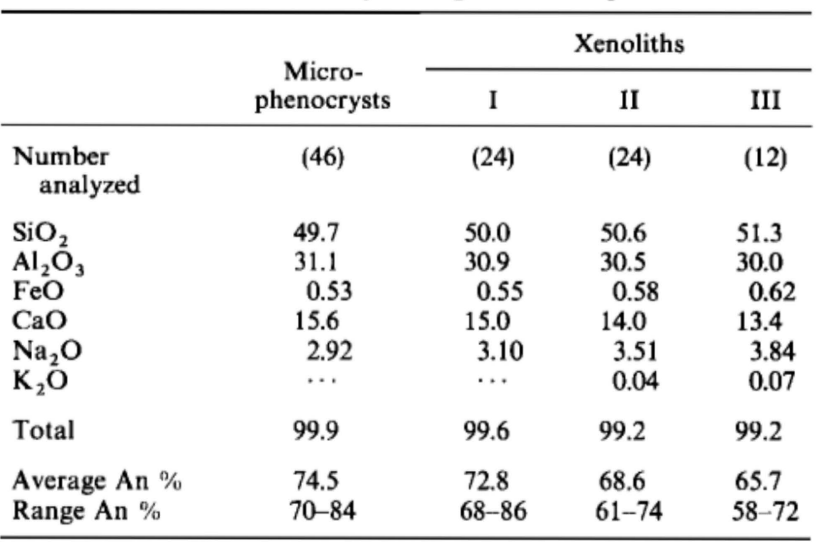

Samples 5-7B and 16-7A consist dominantly of plagioclase and augite in a loose cluster of crystals. Pigeonite, found only during microprobe analysis, has not inverted and is optically continuous with adjacent augite. Minerals in these two samples have moderately differentiated compositions and exhibit zoning and evidence for reaction with the host melt. Zones of abundant glass inclusions occur between augite with different extinction angles and were probably trapped between intergrowing crystals.

Olivine in type III xenoliths is coarser-grained and more iron-rich than microphenocrysts in the host lava and olivine in xenolith types I and II. The average composition is $\mathrm{Fo}_{69.6}$. Olivine in samples $26-1 \mathrm{~A}$ occurs as small $(<1 \mathrm{~mm})$ discrete grains with an average composition of $\mathrm{Fo}_{71,7}$. Olivine in sample 17-3 occurs as two small grains at the edge of the xenolith with composition of $\mathrm{Fo}_{69.9}$. Olivine in sample 5-7A occurs as large $(5 \mathrm{~mm})$ optically continuous subhedral grains and has the widest range in composition. Compositions of the cores of the large olivine grains range from $\mathrm{Fo}_{74.3}$ to $\mathrm{Fo}_{74.8}$. One olivine has a slight zonation from core $\left(\mathrm{Fo}_{72.3}\right)$ to rim $\left(\mathrm{Fo}_{71,0}\right)$. The most iron-rich olivine $\left(\mathrm{Fo}_{63.7}\right)$ occurs in sample 16-7B, a xenolith similar to 5-7A. CaO-contents range from 0.23 to 0.33 wt $\%$ and are lower than $\mathrm{CaO}$ contents of microphenocrysts and olivine in type II xenoliths.

Plagioclase in type III xenoliths is coarser-grained and more complexly zoned than plagioclase in type I and II xenoliths. There is broad compositional overlap between type II and III plagioclase. The average composition of 10 plagioclase analyses is $\mathrm{An}_{65.7}$. In general, increasing iron enrichment in the interstitial glass is accompanied by decreasing An content in the plagioclase.

Plagioclase in sample 26-1A ranges in composition from $\mathrm{An}_{64.8}$ to $\mathrm{An}_{72}$ 0. Two large plagioclase grains enclosed in olivine in sample 5-7A have An contents of 69.0 and $70.2 \%$. 
TABLE 4a. Representative Olivine Analyses

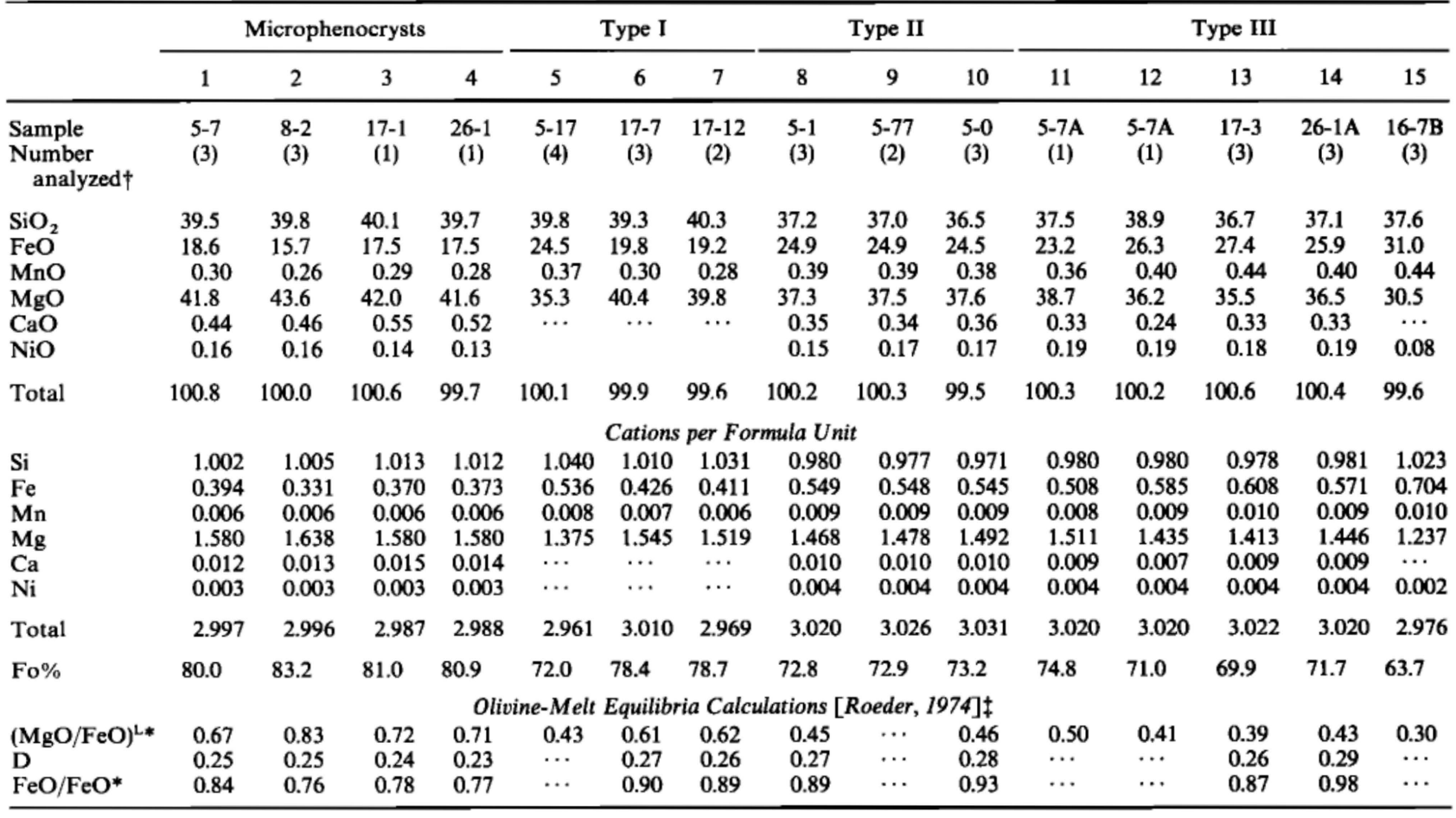

Microphenocrysts from host lava; Type I, II, and III refer to xenoliths. Olivine data were obtained using an ARL-SEMQ automated nine-channel microprobe and reduced using the matrix correction program of Bence and Albee [1968]. Standards used in the analysis of olivine were San Carlos olivine for $\mathrm{Mg}$ and $\mathrm{Si}$; fayalite for $\mathrm{Fe}$ and $\mathrm{Mn}$; and a synthetic Ni-doped diopside. Sample current was $20 \mathrm{nA}$. Backgrounds for $\mathrm{NiO}$ were calculated by hand using a mean atomic number method based on synthetic Ni-free fayalite and $\mathrm{Fo}_{\mathbf{9 7 . 5}}$ from marble.

$\dagger$ Averaged analyses vary less than 0.5 Fo\% $(1 \sigma)$.

$\ddagger$ Calculations use host glass compositions with microphenocrysts and intersertal glass compositions with xenoliths.

Plagioclase in sample 5-8B shows complex zoning; a large, normally zoned plagioclase has a core composition of $\mathrm{An}_{67.9}$ and rim composition of $A n_{58.5}$. Small plagioclase grains in the interstitial glass in samples 5-7A and 16-7A have the most sodic compositions $\left(\mathrm{An}_{\mathbf{5 8 . 0}}\right)$ and reflect the more differentiated composition of the residual liquid. Intergrowths of plagioclase grains commonly have zones of abundant glass inclusions at the grain boundaries.

Pyroxene in type III xenoliths occurs as augite, magnesian pigeonite, and orthopyroxene. Sample 26-1a contains only augite that is fairly equigranular and compositionally homogeneous. Compositions range from $\mathrm{Wo}_{40.2} \mathrm{Fs}_{10.3} \mathrm{En}_{49.5}$ to $\mathrm{Wo}_{39.5} \mathrm{Fs}_{11.8} \mathrm{En}_{48}$. Large augite oikocrysts in samples 5-7A

TABLE $4 b$. Summary of Olivine Compositions

\begin{tabular}{|c|c|c|c|c|}
\hline & \multirow{2}{*}{$\begin{array}{c}\text { Micro- } \\
\text { phenocrysts }\end{array}$} & \multicolumn{3}{|c|}{ Xenoliths } \\
\hline & & I & II & III \\
\hline $\begin{array}{l}\text { Number } \\
\text { analyzed }\end{array}$ & (17) & (3) & (3) & (4) \\
\hline $\mathrm{SiO}_{2}$ & 39.8 & 39.8 & 36.9 & 37.3 \\
\hline $\mathrm{FeO}$ & 17.5 & 21.2 & 24.8 & 27.2 \\
\hline $\mathrm{MnO}$ & 0.28 & 0.32 & 0.39 & 0.42 \\
\hline $\mathrm{MgO}$ & 42.5 & 38.5 & 37.5 & 35.0 \\
\hline $\mathrm{CaO}$ & 0.49 & $\ldots$ & 0.35 & 0.31 \\
\hline $\mathrm{NiO}$ & 0.15 & & 0.16 & 0.19 \\
\hline Total & 100.7 & 99.8 & 100.1 & 100.4 \\
\hline $\begin{array}{l}\text { Average Fo } \% \\
\text { Range Fo \% }\end{array}$ & $\begin{array}{c}81.2 \\
79-83\end{array}$ & $\begin{array}{l}76.4 \\
72-79\end{array}$ & $\begin{array}{c}73.0 \\
72-74\end{array}$ & $\begin{array}{c}69.6 \\
64-75\end{array}$ \\
\hline
\end{tabular}

and 5-8B become more iron-rich toward the margins. Cores of augite oikocrysts have a compositional range of $\mathrm{Wo}_{40}{ }_{5} \mathrm{Fs}_{9.7} \mathrm{En}_{49}$ to $\mathrm{Wo}_{39.2} \mathrm{Fs}_{11.9} \mathrm{En}_{49.0}$ with augite in 5-8B slightly more iron-rich than augite in 5-7A. Core compositions are similar to augite compositions in 26-1A. Points near the edge of an augite oikocryst in sample 5-7A are $\mathrm{Wo}_{37.2} \mathrm{Fs}_{13.3} \mathrm{En}_{49.5}$ and in sample 5-8B are $\mathrm{Wo}_{38.5} \mathrm{Fs}_{17}{ }_{4} \mathrm{En}_{44.1}$.

Augite in sample 5-7B is iron-rich with a core composition of $\mathrm{Wo}_{35.0} \mathrm{Fs}_{16.8} \mathrm{En}_{48.2}$ and a margin composition of $\mathrm{Wo}_{33.8} \mathrm{Fs}_{17{ }_{6}} \mathrm{En}_{48.6}$ (analysis 7 in Table 5). A small grain of pigeonite in sample $5-7 \mathrm{~b}$ has a composition of $\mathrm{Wo}_{8.5} \mathrm{Fs}_{260} \mathrm{En}_{65.5}$ and is optically continuous with the adjacent augite. Augite and pigeonite compositions in sample 16-7A are similar to those in sample 5-7B. A similar occurrence of augite and pigeonite as single crystals and as alternating sectors in complexly zoned phenocrysts has been reported by Byerly [1980] in evolved basalt from the Galapagos spreading center near $95^{\circ} \mathrm{W}$.

Primary pigeonite, partially inverted to host-lamellae pairs of orthopyroxene and augite, occurs as an interstitial phase in 5-7A and 5-8B. Remnant cores of pigeonite have a compositional range of $\mathrm{Wo}_{6.1} \mathrm{Fs}_{23.7} \mathrm{En}_{702}$ to $\mathrm{Wo}_{9.1} \mathrm{Fs}_{25.2} \mathrm{En}_{65.7}$. These compositions are less iron-rich than pigeonite in sample 5-7B. Surrounding these cores of pigeonite are areas of host orthopyroxene with exsolved augite forming blebs microns to tens of microns in width. Augite blebs have compositions of $\mathrm{Wo}_{39.0} \mathrm{Fs}_{12.8} \mathrm{En}_{48.2}$ to $\mathrm{Wo}_{37.2} \mathrm{Fs}_{16.3} \mathrm{En}_{46.4}$ in sample 5-7A and $\mathrm{Wo}_{36.9} \mathrm{Fs}_{14.9} \mathrm{En}_{48.2}$ to $\mathrm{Wo}_{37.6} \mathrm{Fs}_{18.7} \mathrm{En}_{43.6}$ (analysis 19 in Table 5) in sample 5-8B. The exsolved augite has iron contents similar to the margins of the large, zoned augite oikocrysts.

Host orthopyroxene commonly has patchy extinction. 


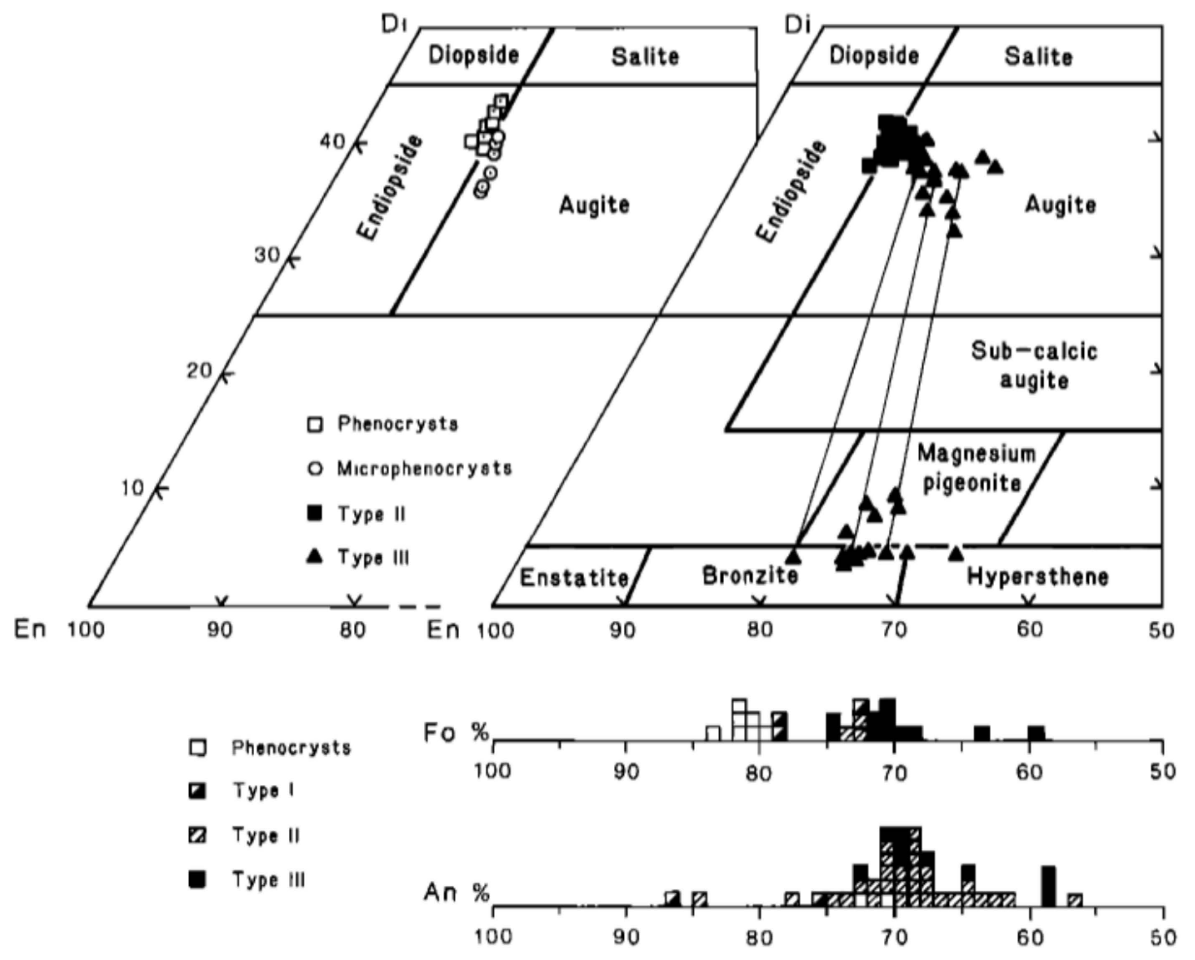

Fig. 6. Pyroxene quadrilaterial and histograms of Fo content in olivine and An content in plagioclase showing the sympathetic compositional variation of coexisting mineral phases in the host lava and xenoliths. The pyroxene quadrilateral on the left shows the large variation of $\mathrm{CaO}$ content at relatively constant $\mathrm{FeO} / \mathrm{MgO}$ ratios for the phenocrysts (sample 8-2) and microphenocrysts related to rapid cooling. The pyroxene quadrilateral on the right shows the iron enrichment trend found in types II and III xenoliths. Magnesium pigeonite and orthopyroxene occur only in type III xenoliths. Tie lines connect pyroxene analyses from inverted pigeonite in samples 5-7A, 5-7B, and 5-8A. Histogram of Fo content in olivine shows the iron enrichment trend in olivine from host lava and xenoliths. Plagioclase compositions show much more overlap than pyroxene or olivine. In general, mineral compositions in types II and III xenoliths overlap, but minerals in type III xenoliths have a wider range in composition, extending to more differentiated compositions.

Ranges in composition in sample 5-7A are $\mathrm{Wo}_{3.9} \mathrm{Fs}_{20.7} \mathrm{En}_{75.4}$ (analysis 22 in Table 5) to $\mathrm{Wo}_{4}{ }_{6} \mathrm{Fs}_{27.2} \mathrm{En}_{68.2}$ (analysis 24 in Table 5) and in sample 5-8B are $\mathrm{Wo}_{4.0} \mathrm{Fs}_{24.1} \mathrm{En}_{71.9}$ to $\mathrm{Wo}_{4,3} \mathrm{Fs}_{32.4} \mathrm{En}_{63}{ }_{3}$ (analysis 26 in Table 5). One discrete grain of orthopyroxene $\left(\mathrm{Wo}_{4.4} \mathrm{Fs}_{26}{ }_{9} \mathrm{En}_{68}\right.$ ) occurs in sample 5-7A. This orthopyroxene grain is adjacent to augite and probably represents complete migration of exsolved augite to the margin of an inverted pigeonite. Much of the scatter in the host-lamellae pair data occurs in the direction of the tie lines and probably reflects overlap of the electron beam on fine exsolution lamellae.

Minor element distribution in host-lamellae pairs are similar to contents in other terrestrial and lunar inverted pigeonites [DeVore, 1955, 1957; Brown, 1957; Carstens, 1958; Ghose et al., 1973; Walker et al., 1973]. $\mathrm{Ti}, \mathrm{Al}$, and $\mathrm{Cr}$ are partitioned into the high-Ca phase, while $\mathrm{Mn}$ is partitioned into the low-Ca phase (Figure 10).

Representative analyses of Fe-Ti oxides are given in Table 6. Table 6 includes calculation methods of Stormer [1983], Anderson [1968], Carmichael [1967], and Lindsley and Spencer [1982] for ulvospinel and ilmenite components, temperature, and oxygen fugacity to allow direct comparison of these data to data from other studies. Due to the high minor element contents ( $\mathrm{Mn}, \mathrm{Mg}, \mathrm{Al}$, and $\mathrm{V}$ ) in the xenolith oxides, the recalculation method of Stormer is used in the text.

Irregular grains of $\mathrm{Fe}-\mathrm{Ti}$ oxides occur within interstitial glass and in interstitial locations in samples 5-7A and 5-8B. Titanomagnetite and ilmenite occur as discrete or composite grains. Titanomagnetite compositions are fairly homogenous; ulvospinel component varies from 59.8 to $63.0 \%$. Con- centrations of minor elements $\left(\mathrm{Al}_{2} \mathrm{O}_{3}, 2.51-3.36 \mathrm{wt} \% ; \mathrm{V}_{2} \mathrm{O}_{3}\right.$, 0.88-1.30 wt \%; MnO, 0.38-0.47 wt \%; MgO, 2.82-4.37 wt $\%)$ are similar to minor element contents in titanomagnetite phenocrysts in ferrobasalt and andesite from the Galapagos Rift [Perfit and Fornari, 1983].

Ilmenite is more abundant than titanomagnetite and exhibits a wider range in composition. $\mathrm{MgO}$ content in ilmenite is higher than in coexisting titanomagnetite. Ilmenite compositions have been subdivided into ilmenite and high-Mg ilmenite. Ilmenite $(<7.0 \mathrm{wt} \% \mathrm{MgO}$ ) occurs as isolated grains or as composite grains with titanomagnetite. Ilmenite component varies from 87.8 to $89.4 \%, \mathrm{MgO}$ contents range from 3.67 to 6.89 wt $\%$, and $\mathrm{Al}_{2} \mathrm{O}_{3}$ ranges from 0.32 to $0.56 \mathrm{wt} \%$. These compositions are similar to, but with slightly higher $\mathrm{MgO}$ contents than, ilmenite from Galapagos Rift lavas [Perfit and Fornari, 1983]. High-Mg ilmenite has $\mathrm{MgO}$ contents of 7.828.44 wt \%. High $\mathrm{MgO}$ content is accompanied by higher $\mathrm{TiO}_{2}$ and lower $\mathrm{Fe}_{2} \mathrm{O}_{3}$ and $\mathrm{FeO}$ contents. Ilmenite component ranges from 89.8 to $93.8 \%$. High-Mg ilmenite occurs only as isolated crystals, but there is no apparent correlation between size of grain; location of grain within the xenolith; surrounding silicate phases; presence of adjacent vapor bubble, sulphide phase, or glass; on ilmenite composition.

Interstitial glasses are more evolved and have a wider compositional range than interstitial glasses in types I or II. $\mathrm{FeO} / \mathrm{MgO}$ ratios (with $\mathrm{FeO}=\mathrm{FeO}^{*} \times 0.9$ ) range from 2.14 to 3.38 (see Table 7). Ranges in minor element contents are $\mathrm{TiO}_{2}=2.31-4.71$ wt $\%, \mathrm{Na}_{2} \mathrm{O}=2.90-3.91$ wt $\%, \mathrm{~K}_{2} \mathrm{O}=$ $0.21-0.69$ wt $\%$, and $\mathrm{P}_{2} \mathrm{O}_{5}=0.24-1.03$ wt $\%$. $\mathrm{CaO} / \mathrm{Al}_{2} \mathrm{O}_{3}$ ratios vary from 0.62 to 0.76 . Interstitial glass compositions 
for sample 5-7A are not reported because of beam overlap on incipiently crystallizing titanomagnetite and apatite.

\section{Glass Inclusions}

Glass inclusions are present in nearly every mineral phase and range in size from less than a micron across to more than a hundred microns in length. They usually exhibit negativecrystal shapes relative to the host crystal showing that they represent small volumes of magma entrapped during the growth of the crystal [Sobolev and Kostyuk, 1975; Roedder, 1979].

Compositions of glass inclusions are presented in Table 8 are plotted on Figure 11a. The wide scatter in the glass inclusion data is related to the type of xenolith, the composition of the host crystal, and the relative degree of crystallization of the inclusion. Glass inclusion compositions define a broad trend of increasing differentiation from type I to type III xenoliths. Analyses of glass inclusions and interstitial glass in each xenolith type have similar ranges in elemental ratios, with the exception of sample 5-17, which compositionally resembles type II xenoliths. Figure $11 b$ shows the parallel trends, on a plot of $\mathrm{FeO}^{*} / \mathrm{CaO}$ and $\mathrm{FeO}^{*} / \mathrm{MgO}$, of data from glass inclusions, interstitial glass, and host lava. Superimposed on this trend is the effect of the growth of the host crystal. Crystallization results in a decrease of $\mathrm{CaO}$ when the inclusion is trapped in plagioclase, a decrease of $\mathrm{MgO}$ when trapped in olivine, or a decrease in $\mathrm{CaO}$ and $\mathrm{MgO}$ when trapped in augite. The distance of the xenolith from the glassy rim of the host lava controls the degree of crystallization of the host crystal [Clocchiatti, 1980]. Thus the xenoliths located farthest from the glassy rim have glass inclusion compositions most displaced from the MORB fractionation trend.

The composition of the original trapped liquid may be calculated, however, by the intersection of fractionation lines of the coexisting host minerals on a triangular oxide plot [Watson, 1976; Clocchiatti, 1977]. Each Juan de Fuca xenolith type contains at least two different coexisting minerals; therefore glass inclusions can be used to estimate the magma composition. These estimated initial compositions are presented in Table 9.

\section{Crystallization Sequence}

In general, the crystallization sequence is coherent for the entire xenolith suite. The presence of euhedral plagioclase grains and its occurrence as inclusions in olivine and augite indicate that plagioclase was the liquidus phase for liquids from which the xenoliths crystallized. Textural evidence suggests that olivine and augite began crystallizing essentially simultaneously; rare intergrowths of olivine in augite and vice versa occur, but olivine and augite more commonly are mutually exclusive. Compositional evidence suggests that olivine may have begun crystallizing slightly earlier than augite be-

TABLE 5. Representative Pyroxene Analyses

\begin{tabular}{|c|c|c|c|c|c|c|c|c|c|c|c|c|c|c|}
\hline & \multicolumn{5}{|c|}{ Phenocrysts } & \multicolumn{5}{|c|}{ Microphenocrysts } & \multicolumn{4}{|c|}{ Type II } \\
\hline & 1 & 2 & 3 & 4 & 5 & 6 & 7 & 8 & 9 & 10 & 11 & 12 & 13 & 14 \\
\hline $\begin{array}{l}\text { Sample } \\
\text { Type }\end{array}$ & $\begin{array}{c}8-2 \\
\text { aug }\end{array}$ & $\begin{array}{l}8-2 \\
\text { aug }\end{array}$ & $\begin{array}{l}8-2 \\
\text { aug }\end{array}$ & $\begin{array}{l}8-2 \\
\text { aug }\end{array}$ & $\begin{array}{l}8-2 \\
\text { aug }\end{array}$ & $\begin{array}{c}22-34 \\
\text { aug }\end{array}$ & $\begin{array}{c}\text { 26-13B } \\
\text { aug }\end{array}$ & $\begin{array}{c}\text { 26-13B } \\
\text { aug }\end{array}$ & $\begin{array}{c}\text { 26-13B } \\
\text { aug }\end{array}$ & $\begin{array}{c}26-13 B \\
\text { aug }\end{array}$ & $\begin{array}{r}5-0 \\
\text { aug }\end{array}$ & $\begin{array}{c}5-1 \\
\text { aug }\end{array}$ & $\begin{array}{c}5-1 \\
\text { aug }\end{array}$ & $\begin{array}{l}17-1 \\
\text { aug }\end{array}$ \\
\hline $\begin{array}{l}\mathrm{SiO}_{2} \\
\mathrm{Al}_{2} \mathrm{O}_{3} \\
\mathrm{FeO}^{*} \\
\mathrm{MgO} \\
\mathrm{CaO} \\
\mathrm{Na}_{2} \mathrm{O} \\
\mathrm{TiO}_{2} \\
\mathrm{Cr}_{2} \mathrm{O}_{3} \\
\mathrm{MnO}\end{array}$ & $\begin{array}{c}51.6 \\
3.63 \\
5.63 \\
16.4 \\
21.1 \\
0.25 \\
0.79 \\
1.15 \\
0.17\end{array}$ & $\begin{array}{c}51.3 \\
3.54 \\
5.67 \\
17.1 \\
20.0 \\
0.23 \\
0.68 \\
1.00 \\
0.20\end{array}$ & $\begin{array}{c}50.5 \\
6.45 \\
5.75 \\
16.0 \\
19.3 \\
0.24 \\
0.72 \\
1.07 \\
0.21\end{array}$ & $\begin{array}{c}53.4 \\
1.80 \\
5.77 \\
18.1 \\
19.9 \\
0.20 \\
0.52 \\
0.60 \\
0.20\end{array}$ & $\begin{array}{c}51.2 \\
3.83 \\
6.15 \\
17.5 \\
19.0 \\
0.24 \\
0.73 \\
0.96 \\
0.20\end{array}$ & $\begin{array}{c}51.8 \\
2.54 \\
7.37 \\
18.3 \\
19.9 \\
\ldots \\
\ldots \\
\ldots \\
\ldots\end{array}$ & $\begin{array}{c}51.7 \\
2.27 \\
6.65 \\
17.6 \\
20.2 \\
\ldots \\
\ldots \\
\ldots \\
\ldots\end{array}$ & $\begin{array}{c}52.0 \\
3.51 \\
6.91 \\
17.7 \\
19.2 \\
\ldots \\
\ldots \\
\ldots \\
\ldots\end{array}$ & $\begin{array}{c}51.6 \\
2.80 \\
7.34 \\
18.8 \\
17.9 \\
\ldots \\
\ldots \\
\ldots \\
\ldots\end{array}$ & $\begin{array}{c}52.7 \\
1.29 \\
7.45 \\
19.0 \\
18.1 \\
\ldots \\
\ldots \\
\ldots \\
\ldots\end{array}$ & $\begin{array}{c}52.5 \\
2.40 \\
6.09 \\
17.4 \\
20.3 \\
0.23 \\
0.53 \\
0.26 \\
0.20\end{array}$ & $\begin{array}{c}51.9 \\
3.08 \\
5.99 \\
17.4 \\
20.4 \\
0.25 \\
0.55 \\
0.41 \\
0.23\end{array}$ & $\begin{array}{c}52.3 \\
2.02 \\
8.56 \\
17.2 \\
18.9 \\
0.25 \\
0.65 \\
0.04 \\
0.31\end{array}$ & $\begin{array}{c}53.2 \\
2.49 \\
6.19 \\
17.9 \\
20.2 \\
0.24 \\
0.51 \\
0.31 \\
0.23\end{array}$ \\
\hline Total & 100.7 & 99.7 & 100.2 & 100.5 & 99.8 & 99.9 & 98.3 & 99.2 & 98.4 & 98.5 & 99.9 & 100.2 & 100.4 & 101.2 \\
\hline $\begin{array}{l}\mathrm{Si} \\
\mathrm{Al} \\
\mathrm{Fe} \\
\mathrm{Mg} \\
\mathrm{Ca} \\
\mathrm{Na} \\
\mathrm{Ti} \\
\mathrm{Cr} \\
\mathrm{Mn}\end{array}$ & $\begin{array}{l}1.880 \\
0.156 \\
0.172 \\
0.891 \\
0.824 \\
0.018 \\
0.022 \\
0.033 \\
0.005\end{array}$ & $\begin{array}{l}1.882 \\
0.153 \\
0.174 \\
0.935 \\
0.786 \\
0.016 \\
0.019 \\
0.029 \\
0.006\end{array}$ & $\begin{array}{l}1.842 \\
0.277 \\
0.175 \\
0.870 \\
0.754 \\
0.017 \\
0.020 \\
0.031 \\
0.006\end{array}$ & $\begin{array}{l}1.941 \\
0.077 \\
0.175 \\
0.980 \\
0.775 \\
0.014 \\
0.014 \\
0.017 \\
0.006\end{array}$ & $\begin{array}{l}1.875 \\
0.165 \\
0.188 \\
0.955 \\
0.745 \\
0.017 \\
0.020 \\
0.028 \\
0.006\end{array}$ & $\begin{array}{c}\text { Cations } \\
1.891 \\
0.109 \\
0.225 \\
0.996 \\
0.778 \\
\ldots \\
\ldots \\
\ldots \\
\ldots\end{array}$ & $\begin{array}{c}\text { per Forme } \\
1.918 \\
0.099 \\
0.206 \\
0.973 \\
0.803 \\
\ldots \\
\ldots \\
\ldots \\
\ldots\end{array}$ & $\begin{array}{l}\text { ula Unit } \\
1.911 \\
0.152 \\
0.212 \\
0.969 \\
0.756 \\
\ldots \\
\ldots \\
\ldots \\
\ldots\end{array}$ & $\begin{array}{l}1.907 \\
0.122 \\
0.227 \\
1.036 \\
0.709 \\
\ldots \\
\ldots \\
\ldots \\
\ldots\end{array}$ & $\begin{array}{l}1.949 \\
0.056 \\
0.230 \\
1.047 \\
0.717 \\
\ldots \\
\ldots \\
\ldots \\
\ldots\end{array}$ & $\begin{array}{l}1.927 \\
0.104 \\
0.187 \\
0.951 \\
0.798 \\
0.016 \\
0.015 \\
0.008 \\
0.006\end{array}$ & $\begin{array}{l}1.901 \\
0.133 \\
0.183 \\
0.952 \\
0.798 \\
0.018 \\
0.015 \\
0.012 \\
0.007\end{array}$ & $\begin{array}{l}1.927 \\
0.088 \\
0.264 \\
0.946 \\
0.748 \\
0.018 \\
0.018 \\
0.001 \\
0.010\end{array}$ & $\begin{array}{l}1.925 \\
0.106 \\
0.187 \\
0.964 \\
0.783 \\
0.017 \\
0.014 \\
0.009 \\
0.007\end{array}$ \\
\hline Total & 4.001 & 4.000 & 3.992 & 3.999 & 3.999 & 3.999 & 3.999 & 3.999 & 4.001 & 3.999 & 4.012 & 4.019 & 4.020 & 4.012 \\
\hline $\begin{array}{l}\text { Wo } \\
\text { En } \\
\text { Fs } \\
\text { Others }\end{array}$ & $\begin{array}{r}38.3 \\
53.0 \\
8.7 \\
12.9\end{array}$ & $\begin{array}{r}36.1 \\
55.5 \\
8.4 \\
12.8\end{array}$ & $\begin{array}{l}31.4 \\
57.1 \\
11.5 \\
17.6\end{array}$ & $\begin{array}{r}37.7 \\
53.3 \\
9.0 \\
7.0\end{array}$ & $\begin{array}{c}\text { Mineral } \Lambda \\
33.9 \\
56.9 \\
9.2 \\
13.5\end{array}$ & $\begin{array}{l}\text { Norm }[L i \\
33.5 \\
59.5 \\
7.0 \\
10.9\end{array}$ & $\begin{array}{l}\text { ndsley anc } \\
36.1 \\
55.8 \\
8.1 \\
8.2\end{array}$ & $\begin{array}{c}\text { Anderser } \\
33.3 \\
56.0 \\
10.7 \\
9.0\end{array}$ & $\begin{array}{c}n, 1983] \\
30.8 \\
59.8 \\
9.4 \\
9.3\end{array}$ & $\begin{array}{r}33.3 \\
56.7 \\
10.0 \\
5.1\end{array}$ & $\begin{array}{r}38.1 \\
53.3 \\
8.6 \\
9.1\end{array}$ & $\begin{array}{l}\cdots \\
\cdots \\
\cdots \\
12.2\end{array}$ & $\begin{array}{r}35.8 \\
52.6 \\
11.6 \\
9.4\end{array}$ & $\begin{array}{r}37.2 \\
54.4 \\
8.4 \\
9.5\end{array}$ \\
\hline $\begin{array}{l}\text { Calculated } \\
\mathrm{Fe}_{2} \mathrm{O}_{3}\end{array}$ & 0.90 & 1.21 & 0.00 & 0.37 & 1.24 & 3.94 & $\begin{array}{c}2.31 \\
\text { neral Nor }\end{array}$ & 0.97 & 2.31 & 1.65 & 1.25 & 2.19 & 1.98 & 1.38 \\
\hline $\begin{array}{l}\text { Wo } \\
\text { En } \\
\text { Fs }\end{array}$ & $\begin{array}{r}43.7 \\
47.2 \\
9.1\end{array}$ & $\begin{array}{r}41.5 \\
49.3 \\
9.2\end{array}$ & $\begin{array}{r}41.9 \\
48.6 \\
9.5\end{array}$ & $\begin{array}{r}40.1 \\
50.8 \\
9.1\end{array}$ & $\begin{array}{l}39.4 \\
50.6 \\
10.0\end{array}$ & $\begin{array}{l}39.0 \\
50.0 \\
11.0\end{array}$ & $\begin{array}{l}40.5 \\
49.1 \\
10.4\end{array}$ & $\begin{array}{l}39.0 \\
50.0 \\
10.9\end{array}$ & $\begin{array}{l}36.0 \\
52.5 \\
11.5\end{array}$ & $\begin{array}{l}36.0 \\
52.5 \\
11.5\end{array}$ & $\begin{array}{r}41.2 \\
49.1 \\
9.7\end{array}$ & $\begin{array}{r}41.3 \\
49.2 \\
9.5\end{array}$ & $\begin{array}{l}38.2 \\
48.3 \\
13.5\end{array}$ & $\begin{array}{r}40.5 \\
49.8 \\
9.7\end{array}$ \\
\hline
\end{tabular}


TABLE 5. (continued)

\begin{tabular}{|c|c|c|c|c|c|c|c|c|c|c|c|c|}
\hline & \multicolumn{12}{|c|}{ Type III } \\
\hline & 15 & 16 & 17 & 18 & 19 & 20 & 21 & 22 & 23 & 24 & 25 & 26 \\
\hline $\begin{array}{l}\text { Sample } \\
\text { Type }\end{array}$ & $\begin{array}{c}26-1 \mathrm{~A} \\
\text { aug }\end{array}$ & $\begin{array}{c}5-7 \mathrm{~A} \\
\text { aug }\end{array}$ & $\begin{array}{c}5-7 \mathrm{~B} \\
\text { aug }\end{array}$ & $\begin{array}{c}\text { 5-7A } \\
\text { aug-ex }\end{array}$ & $\begin{array}{c}5-8 B \\
\text { aug-ex }\end{array}$ & $\begin{array}{c}5-7 \mathrm{~A} \\
\text { pig }\end{array}$ & $\begin{array}{c}\text { 5-7B } \\
\text { pig }\end{array}$ & $\begin{array}{l}5-7 A \\
\text { opx }\end{array}$ & $\begin{array}{l}\text { 5-7A } \\
\text { opx }\end{array}$ & $\begin{array}{l}5-7 \mathrm{~A} \\
\text { opx }\end{array}$ & $\begin{array}{l}5-8 B \\
\text { opx }\end{array}$ & $\begin{array}{l}\text { 5-8B } \\
\text { opx }\end{array}$ \\
\hline $\begin{array}{l}\mathrm{SiO}_{2} \\
\mathrm{Al}_{2} \mathrm{O}_{3} \\
\mathrm{FeO}^{*} \\
\mathrm{MgO} \\
\mathrm{CaO} \\
\mathrm{Na}_{2} \mathrm{O} \\
\mathrm{TiO}_{2} \\
\mathrm{Cr}_{2} \mathrm{O}_{3} \\
\mathrm{MnO}\end{array}$ & $\begin{array}{c}52.5 \\
2.18 \\
6.69 \\
17.5 \\
19.7 \\
0.22 \\
0.51 \\
0.09 \\
0.23\end{array}$ & $\begin{array}{c}53.1 \\
1.83 \\
6.85 \\
17.9 \\
19.6 \\
0.22 \\
0.45 \\
0.09 \\
0.26\end{array}$ & $\begin{array}{c}51.8 \\
2.04 \\
11.1 \\
17.3 \\
16.7 \\
0.29 \\
0.78 \\
0.09 \\
0.38\end{array}$ & $\begin{array}{c}51.9 \\
2.16 \\
9.49 \\
17.7 \\
17.3 \\
0.23 \\
0.75 \\
0.06 \\
0.33\end{array}$ & $\begin{array}{c}51.8 \\
2.02 \\
11.7 \\
15.3 \\
18.3 \\
0.30 \\
1.01 \\
0.02 \\
0.40\end{array}$ & $\begin{array}{c}53.6 \\
1.00 \\
15.6 \\
24.7 \\
4.33 \\
0.07 \\
0.41 \\
0.03 \\
0.47\end{array}$ & $\begin{array}{c}53.4 \\
0.86 \\
17.0 \\
24.1 \\
4.30 \\
0.08 \\
0.35 \\
0.05 \\
0.51\end{array}$ & $\begin{array}{c}54.0 \\
1.20 \\
13.7 \\
28.0 \\
2.03 \\
0.02 \\
0.61 \\
0.04 \\
0.40\end{array}$ & $\begin{array}{c}53.7 \\
0.82 \\
16.3 \\
26.0 \\
2.07 \\
0.03 \\
0.33 \\
0.04 \\
0.44\end{array}$ & $\begin{array}{c}53.5 \\
0.76 \\
17.8 \\
25.0 \\
2.34 \\
0.03 \\
0.48 \\
0.03 \\
0.53\end{array}$ & $\begin{array}{c}53.2 \\
0.96 \\
18.7 \\
24.2 \\
2.26 \\
0.03 \\
0.54 \\
0.03 \\
0.53\end{array}$ & $\begin{array}{c}53.0 \\
0.88 \\
20.8 \\
22.8 \\
2.16 \\
0.02 \\
0.50 \\
0.03 \\
0.57\end{array}$ \\
\hline Total & 99.7 & 100.3 & 100.5 & 100.0 & 100.8 & 100.2 & 100.6 & 100.0 & 99.7 & 100.4 & 100.5 & 100.9 \\
\hline $\begin{array}{l}\mathrm{Si} \\
\mathrm{Al} \\
\mathrm{Fe} \\
\mathrm{Mg} \\
\mathrm{Ca} \\
\mathrm{Na} \\
\mathrm{Ti} \\
\mathrm{Cr} \\
\mathrm{Mn}\end{array}$ & $\begin{array}{l}1.934 \\
0.094 \\
0.206 \\
0.959 \\
0.779 \\
0.016 \\
0.014 \\
0.003 \\
0.007\end{array}$ & $\begin{array}{l}1.941 \\
0.079 \\
0.209 \\
0.978 \\
0.769 \\
0.015 \\
0.012 \\
0.003 \\
0.008\end{array}$ & $\begin{array}{l}1.918 \\
0.089 \\
0.345 \\
0.954 \\
0.662 \\
0.021 \\
0.022 \\
0.003 \\
0.012\end{array}$ & $\begin{array}{l}1.921 \\
0.094 \\
0.293 \\
0.977 \\
0.685 \\
0.016 \\
0.021 \\
0.002 \\
0.010\end{array}$ & $\begin{array}{c}\text { Cations } \\
1.925 \\
0.089 \\
0.363 \\
0.845 \\
0.729 \\
0.022 \\
0.028 \\
0.001 \\
0.012\end{array}$ & $\begin{array}{r}\text { per Formu } \\
1.954 \\
0.043 \\
0.474 \\
1.343 \\
0.169 \\
0.005 \\
0.011 \\
0.001 \\
0.015\end{array}$ & $\begin{array}{l}\text { Unit } \\
1.953 \\
0.037 \\
0.519 \\
1.311 \\
0.168 \\
0.006 \\
0.010 \\
0.002 \\
0.016\end{array}$ & $\begin{array}{l}1.943 \\
0.051 \\
0.412 \\
1.500 \\
0.078 \\
0.001 \\
0.016 \\
0.001 \\
0.012\end{array}$ & $\begin{array}{l}1.961 \\
0.035 \\
0.498 \\
1.412 \\
0.081 \\
0.002 \\
0.009 \\
0.001 \\
0.014\end{array}$ & $\begin{array}{l}1.956 \\
0.033 \\
0.543 \\
1.360 \\
0.092 \\
0.002 \\
0.013 \\
0.001 \\
0.016\end{array}$ & $\begin{array}{l}1.951 \\
0.042 \\
0.574 \\
1.323 \\
0.089 \\
0.002 \\
0.015 \\
0.001 \\
0.016\end{array}$ & $\begin{array}{l}1.955 \\
0.038 \\
0.642 \\
1.256 \\
0.085 \\
0.001 \\
0.014 \\
0.001 \\
0.018\end{array}$ \\
\hline Total & 4.012 & 4.014 & 4.026 & 4.019 & 4.014 & 4.015 & 4.022 & 4.014 & 4.013 & 4.016 & 4.013 & 4.010 \\
\hline $\begin{array}{l}\text { Wo } \\
\text { En } \\
\text { Fs } \\
\text { Others }\end{array}$ & $\begin{array}{r}37.3 \\
53.2 \\
9.5 \\
8.4\end{array}$ & $\begin{array}{r}37.1 \\
53.5 \\
9.4 \\
7.8\end{array}$ & $\begin{array}{l}\ldots \\
\cdots \\
\cdots \\
10.4\end{array}$ & \begin{tabular}{l}
\multicolumn{2}{c}{ Miner } \\
$\ldots$ \\
$\ldots$ \\
$\ldots$ \\
10.0
\end{tabular} & $\begin{array}{c}\text { Norm }[\mathrm{Li} \\
36.0 \\
46.4 \\
17.6 \\
9.7\end{array}$ & $\begin{array}{c}\text { dsley and } \\
9.8 \\
67.5 \\
22.7 \\
5.0\end{array}$ & $\begin{array}{c}\text { Andersen, } \\
9.0 \\
66.0 \\
25.0 \\
4.6\end{array}$ & $\begin{array}{r}83] \\
4.0 \\
76.0 \\
20.0 \\
5.0\end{array}$ & $\begin{array}{r}4.2 \\
71.6 \\
24.3 \\
4.0\end{array}$ & $\begin{array}{r}4.7 \\
68.4 \\
27.0 \\
3.6\end{array}$ & $\begin{array}{r}4.6 \\
67.0 \\
28.0 \\
4.4\end{array}$ & $\begin{array}{r}4.4 \\
63.6 \\
32.0 \\
4.2\end{array}$ \\
\hline $\begin{array}{l}\text { Calculated } \\
\mathrm{Fe}_{2} \mathrm{O}_{3}\end{array}$ & 1.26 & 1.39 & 2.29 & 2.07 & 1.51 & 0.90 & 0.80 & 0.67 & 0.66 & 0.28 & 0.47 & 0.40 \\
\hline \multicolumn{13}{|c|}{ Mineral Norm* } \\
\hline $\begin{array}{l}\text { Wo } \\
\text { En } \\
\text { Fs }\end{array}$ & $\begin{array}{l}40.1 \\
49.3 \\
10.6\end{array}$ & $\begin{array}{l}39.3 \\
50.0 \\
10.7\end{array}$ & $\begin{array}{l}33.8 \\
48.6 \\
17.6\end{array}$ & $\begin{array}{l}35.0 \\
50.0 \\
15.0\end{array}$ & $\begin{array}{l}37.6 \\
43.6 \\
18.7\end{array}$ & $\begin{array}{r}8.5 \\
67.6 \\
23.9\end{array}$ & $\begin{array}{r}8.4 \\
65.6 \\
26.0\end{array}$ & $\begin{array}{r}3.9 \\
75.4 \\
20.7\end{array}$ & $\begin{array}{r}4.1 \\
70.9 \\
25.0\end{array}$ & $\begin{array}{r}4.6 \\
68.2 \\
27.2\end{array}$ & $\begin{array}{r}4.5 \\
66.6 \\
28.9\end{array}$ & $\begin{array}{r}4.3 \\
63.3 \\
32.4\end{array}$ \\
\hline
\end{tabular}

Analysis 12 from core or oikocryst; 13 from small grain at edge of xenolith; analyses 18,23 and 19,25 are host-lamellae pairs. Pyroxene data were obtained using a ARL-SEMQ automated nine-channel microprobe and reduced using the matrix correction program of Bence and Albee [1968] Standards used in analysis of pyroxene were synthetic Di-Jd for $\mathrm{Si}, \mathrm{Ca}, \mathrm{Mg}, \mathrm{Na}$, and $\mathrm{Al} ; \mathrm{TiO}_{2}$ for $\mathrm{Ti}_{3} \mathrm{Cr}_{2} \mathrm{O}_{3}$ for $\mathrm{Cr} ; \mathrm{Mn}_{2} \mathrm{O}_{3}$ for $\mathrm{Mn}$; and fayalite for $\mathrm{Fe}$. Sample current was $20 \mathrm{nA}$, and counting time was $60 \mathrm{~s}$.

${ }^{*} \mathrm{Wo}=\mathrm{Ca} /(\mathrm{Ca}+\mathrm{Mg}+\mathrm{Fe}) ; \mathrm{En}=\mathrm{Mg} /(\mathrm{Ca}+\mathrm{Mg}+\mathrm{Fe}) ; \mathrm{Fs}=\mathrm{Fe} /(\mathrm{Ca}+\mathrm{Mg}+\mathrm{Fe})$.

†aug $=$ augite ; aug-ex $=$ exsolved augite $;$ pig $=$ pigeonite opx $=$ orthopyroxene

cause the least evolved compositions are from type I (olivine + plagioclase) xenoliths. Primary pigeonite occupies interstitial positions and is a late crystallizing phase. Fe-Ti oxides were the last phases to crystallize and occur in the interstitial glass or along grain boundaries.

These observations suggest the following paragenetic sequence for the xenoliths: initial crystallization of plagioclase followed by plagioclase + olivine + augite, plagioclase + olivine + augite + pigeonite, and plagioclase + olivine + augite + inversion of pigeonite $+\mathrm{Fe}-\mathrm{Ti}$ oxides. After crystallization of pigeonite and $\mathrm{Fe}-\mathrm{Ti}$ oxides the xenoliths underwent ductile deformation, indicated by subtle kink banding in olivine, and brittle fracture, indicated by melt-filled fractures crosscutting the most crystalline xenoliths. Quenching of the xenoliths in the host lava preserved the different stages in the crystallization history.

The crystallization sequence defined by the xenoliths is similar to the sequence found in lavas from the Galapagos spreading center at approximately $85^{\circ} \mathrm{W}$. Perfit and Fornari [1983] found the following crystallization sequence in Gala- pagos lavas: initial crystallization of plagioclase + olivine followed by plagioclase + augite + olivine, plagioclase + augite + pigeonite, and plagioclase + augite + pigeonite $+\mathrm{FeTi}$ oxides. In the Galapagos lavas, olivine ceases to crystallize in ferrobasalt containing small microphenocrysts of pigeonite. The coexistence of olivine and pigeonite in the most crystalline xenoliths reflects the metastable assemblage caused by continued differentiation of the residual melt during in situ crystallization. The crystallization sequence found in the Juan de Fuca Ridge xenoliths and Galapagos spreading center lavas differs from results of crystallization experiments done on a differentiated sample from the Oceanographer Fracture Zone [Walker et al., 1979] in the lack of chromian spinel as a near-liquidus phase, the occurrence of olivine before augite, and the occurrence of magnetite.

\section{General Mineral Trends}

Figure 6 is a compilation of pyroxene, olivine, and plagioclase data for phenocrysts, microphenocrysts, and xenoliths. Figure 8 shows the compositional trends of hot and interstitial 

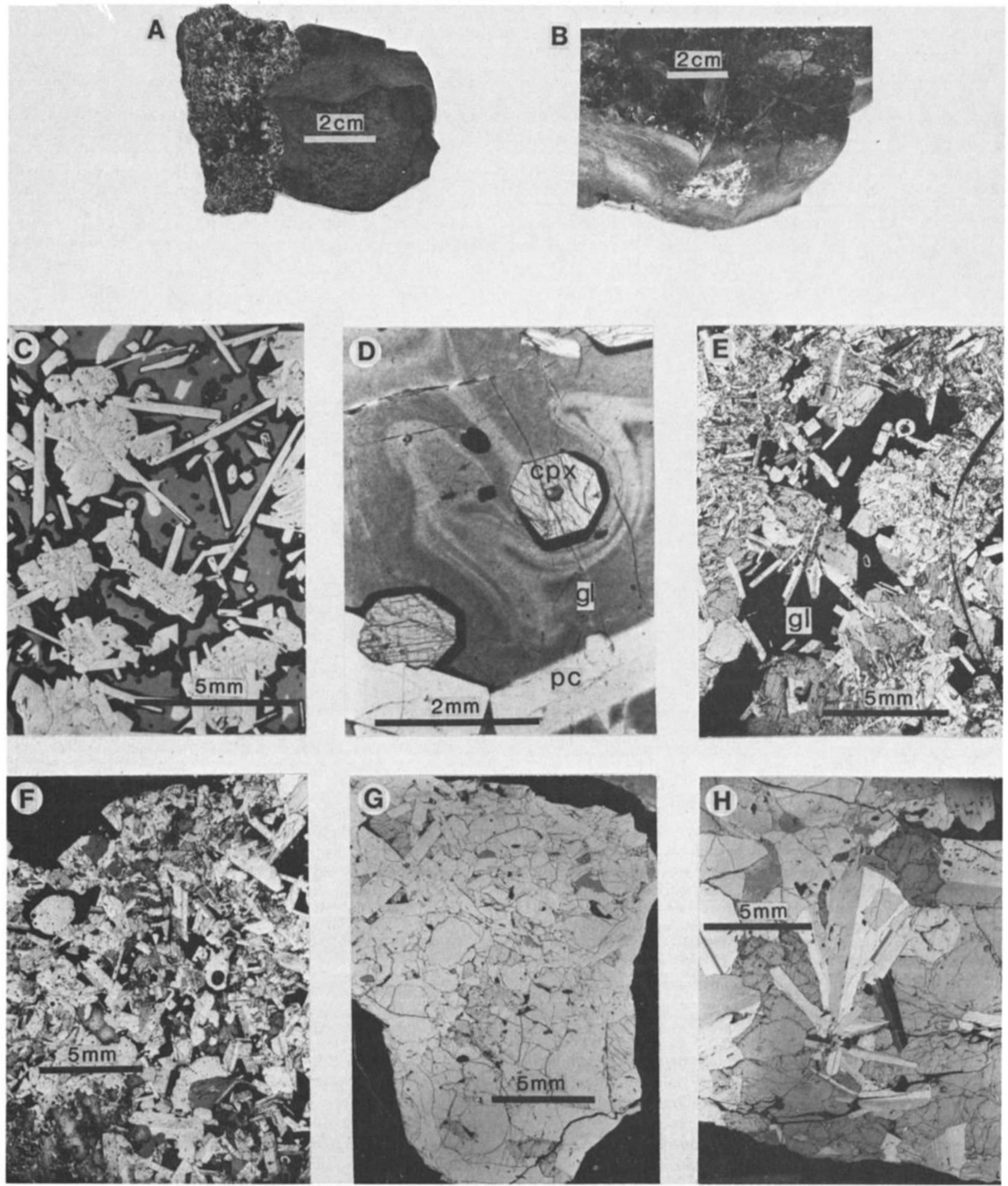

Fig. 7. Photographs and photomicrographs of xenoliths in basalt from the Juan de Fuca Ridge. (a) Sample 5-0; medium-grained gabbroic xenolith enclosed in aphyric host lava. Black near end of scale bar is interstitial glass. (b) Sample 5-7A; type III xenolith exposed on fracture surface of sheet flow fragment. Note sharp textural contrast between aphyric host lava and xenolith. (c) Sample 17-1A; open textured, glassy xenolith. Plagioclase laths (white) are subophitically surrounded by augite. Dark grey is glass. Augite and plagioclase contain abundant glass inclusions. Plane light. (d) Sample 17-1A; close-up of flowage texture in glass around augite crystal. Plane light. (e) Sample 5-0; photomicrograph of section cut through sample shown in Figure 7a. Ophitic texture with augite (light grey with well-developed cleavage) surrounding plagiclase laths (white). Sprays of plagioclase laths extend into interstitial glass (black, center of photo). Crossed nicols. $(f)$ Sample 26-1A; medium-grained, fairly equigranular xenolith. Black material in upper left of photo is host lava; black material within xenolith is interstitial glass. Augite (grey) and plagioclase (white and light grey) are dominant minerals. Crossed nicols. (g) Sample 5-7A; coarse-grained type III xenolith. Olivine (light grey with irregular fractures) and plagioclase are the dominant minerals. Pyroxene is a darker grey. An inverted pigeonite can be seen just above the left end of the scale bar; Figure $9 b$ is a close-up of this pigeonite. Plane light. (h) Sample 5-8B; coarsed-grained type III xenolith. Large plagioclase in middle of photo. Augite is medium grey in lower half of xenolith. Olivine is light grey with irregular fractures in the central upper portion of the photo. Close-up of plagioclase and pyroxene intergrowth texture found in upper right edge of photo appears in Figure $9 a$. 


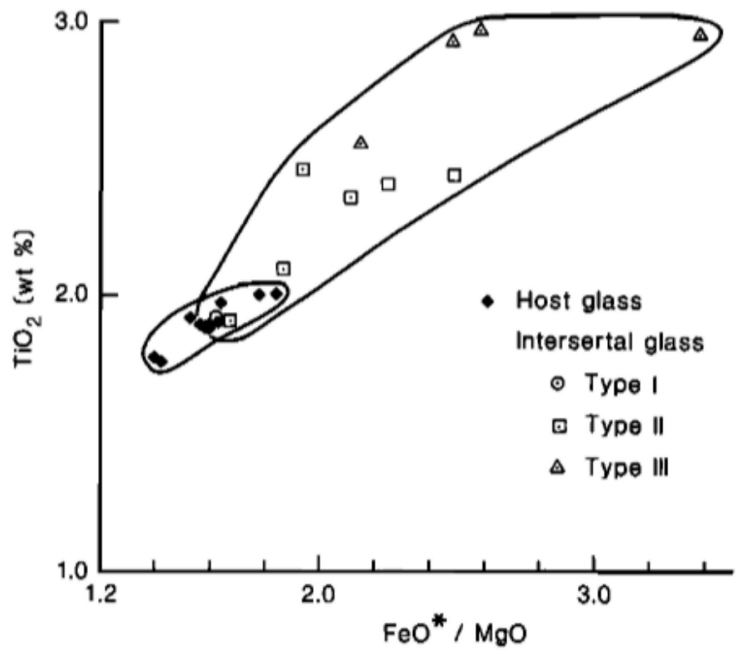

Fig. $8 a$

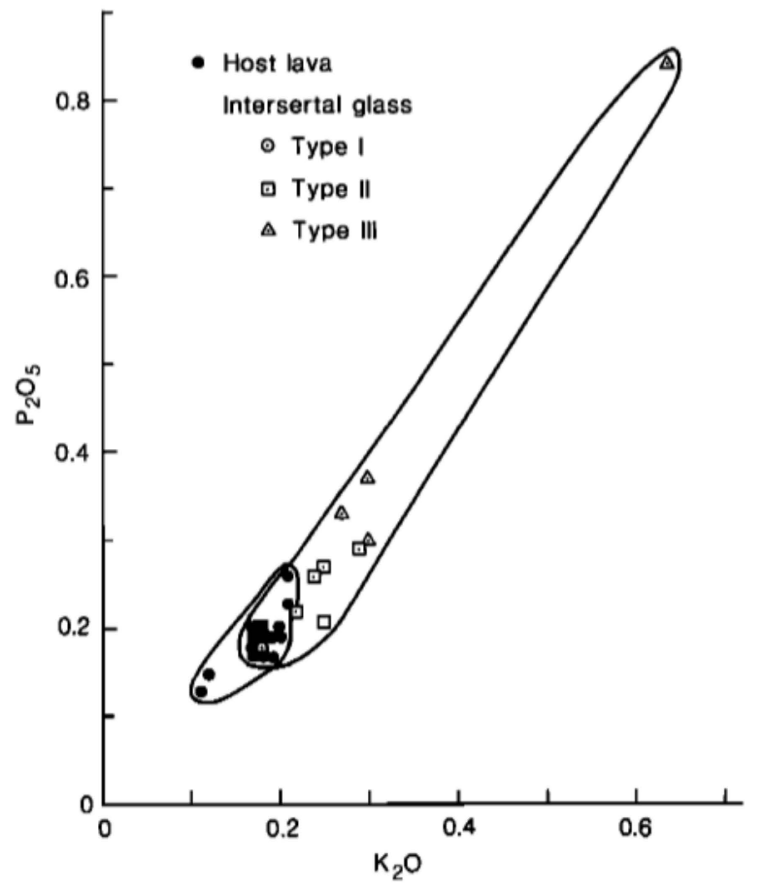

Fig. $8 b$

Fig. 8. Major and minor element variation diagrams showing evolved interstitial glass compositions relative to host lava compositions. (a) $\mathrm{TiO}_{2}$ versus $\mathrm{FeO}^{*} / \mathrm{MgO}$ plot shows the increasing $\mathrm{TiO}_{2}$ and $\mathrm{FeO}^{*}$ contents with increasing differentiation. (b) $\mathrm{P}_{2} \mathrm{O}_{5}$ versus $\mathrm{K}_{2} \mathrm{O}$ plot shows enrichment of incompatible elements in the interstitial melts during differentiation.

glasses. The transition from type I to type III xenoliths is marked by sympathetic compositional variation of coexisting augite, plagioclase, olivine, and glass. Minerals in the xenoliths are more evolved than phenocrysts and microphenocrysts in the host lavas. The Fe-enrichment trends defined by analyses of mafic phases are similar to trends defined by phenocrysts in lavas from the Galapagos spreading center [Byerly, 1980; Perfit and Fornari, 1983], oceanic gabbros [Miyashiro and Shido, 1980; Tiezzi and Scott, 1980; Vanko and Batiza, 1982; Hebert et al., 1983], and other tholeiitic intrusions such as the Skaergaard [Wager and Deer, 1939], the Stillwater Complex [Hess, 1960], and the Bushveld [Truter, 1955].

Plagioclase shows a less systematic variation between xenolith types. Plagioclase in type II and type III xenoliths show similar ranges in composition but are more sodic than those in type I xenoliths or the microphenocrysts.

Olivine analyses provide the most conclusive evidence that the xenoliths formed in equilibrium with melts more evolved than the host lavas because olivine-liquid $\mathrm{Fe} / \mathrm{Mg}$ partitioning is independent of temperature [Roeder, 1974]. Olivine-melt equilibrium calculations for microphenocrysts and host lava using $D_{\text {ol-Liq }}=(\mathrm{MgO} / \mathrm{FeO})_{\text {Liq }} \cdot(\mathrm{FeO} / \mathrm{MgO})_{\text {ol }}[$ Roeder, 1974] indicate that the distribution coefficient $\left(D_{\text {ol-Liq }}\right)$ is approximately 0.24 (assuming that all iron is $\mathrm{FeO}$ ). An assumed distribution coefficient of 0.30 results in calculated $\mathrm{FeO} / \mathrm{FeO}^{*}$ ratios of 0.74-0.84. Perfit and Fornari [1983] arrived at a similar conclusion for olivine phenocrysts from the Galapagos spreading center.

Olivine shows and Fe-enrichment trend from type I to type III (Figure 12). In contrast to the host lava-microphenocryst equilibria, however, the xenolith olivine-interstitial glass equilibria calculations are consistent with the melt having $\mathrm{FeO} /$ $\mathrm{FeO}^{*}$ ratio of 0.9 and olivine-melt distribution coefficient of approximately 0.30 . The higher $\mathrm{FeO} / \mathrm{FeO}^{*}$ ratios imply that the conditions of formation of the gabbros are more reduced than the conditions of formation of the microphenocrysts.

Pyroxene shows a systematic decrease in $\mathrm{Cr}_{2} \mathrm{O}_{3}$, increase in $\mathrm{TiO}_{2}$, and slight decrease in $\mathrm{Al}_{2} \mathrm{O}_{3}$ with increasing $\mathrm{Fe} /$ $(\mathrm{Fe}+\mathrm{Mg}$ ) ratio (Figure 10 ). These data suggest that the xenoliths are comagmatic. Augite compositions of type II and type III xenoliths overlap, but the most Fe-enriched augite occurs in a type III xenolith with partially inverted pigeonite. Compositions of augite phenocrysts and microphenocrysts do not follow the $\mathrm{Fe}$-enrichment trend defined by the different xenolith types but instead are depleted in $\mathrm{Ca}\left(\mathrm{Wo}_{37.40}\right)$ and enriched in $\mathrm{Al}$ at relatively constant $\mathrm{Fe} / \mathrm{Mg}$ ratios. Similar trends have been noted in Ca-pyroxenes from DSDP hole 425 [Mattey and Muir, 1980] and hole 319 [Mazzullo and Bence, 1976]. The $\mathrm{Ca}$ depletion trend has been related to kinetic effects upon quenching [Natland, 1980].

Partitioning of $\mathrm{FeO}$ and $\mathrm{MgO}$ between coexisting clinopyroxene and glass is shown on Figure 13. Calculated $K_{D}=$ $\left(\mathrm{FeO}^{*} / \mathrm{MgO}\right)_{\mathrm{CPX}} /(\mathrm{FeO} * \mathrm{MgO})_{\text {Liq }}$ are 0.21 for phenocrysts-host glass pairs and 0.150 .20 for xenolith pyroxene-interstitial glass pairs. Lower $K_{D}$ calculated for the xenoliths imply that they formed under more reduced conditions than the phenocrysts, consistent with the olivine data. These values are lower than the 0.26 average value reported for the FAMOUS area [Bryan, 1979].

The occurrence of high $\mathrm{Mg}$ contents in ilmenite and the existence of such wide ranges of compositions within single xenoliths are unusual in an oceanic environment. $\mathrm{MgO}$ contents in oceanic samples rarely exceed $5.5 \mathrm{wt} \%$ [Haggerty, 1976; Byerly, 1980; Perfit and Fornari, 1983]. The most influential factor controlling ilmenite chemistry is the composition of the magma from which it crystallized. Magnesian ilmenite is characteristic of kimberlites, where it forms in equilibrium 

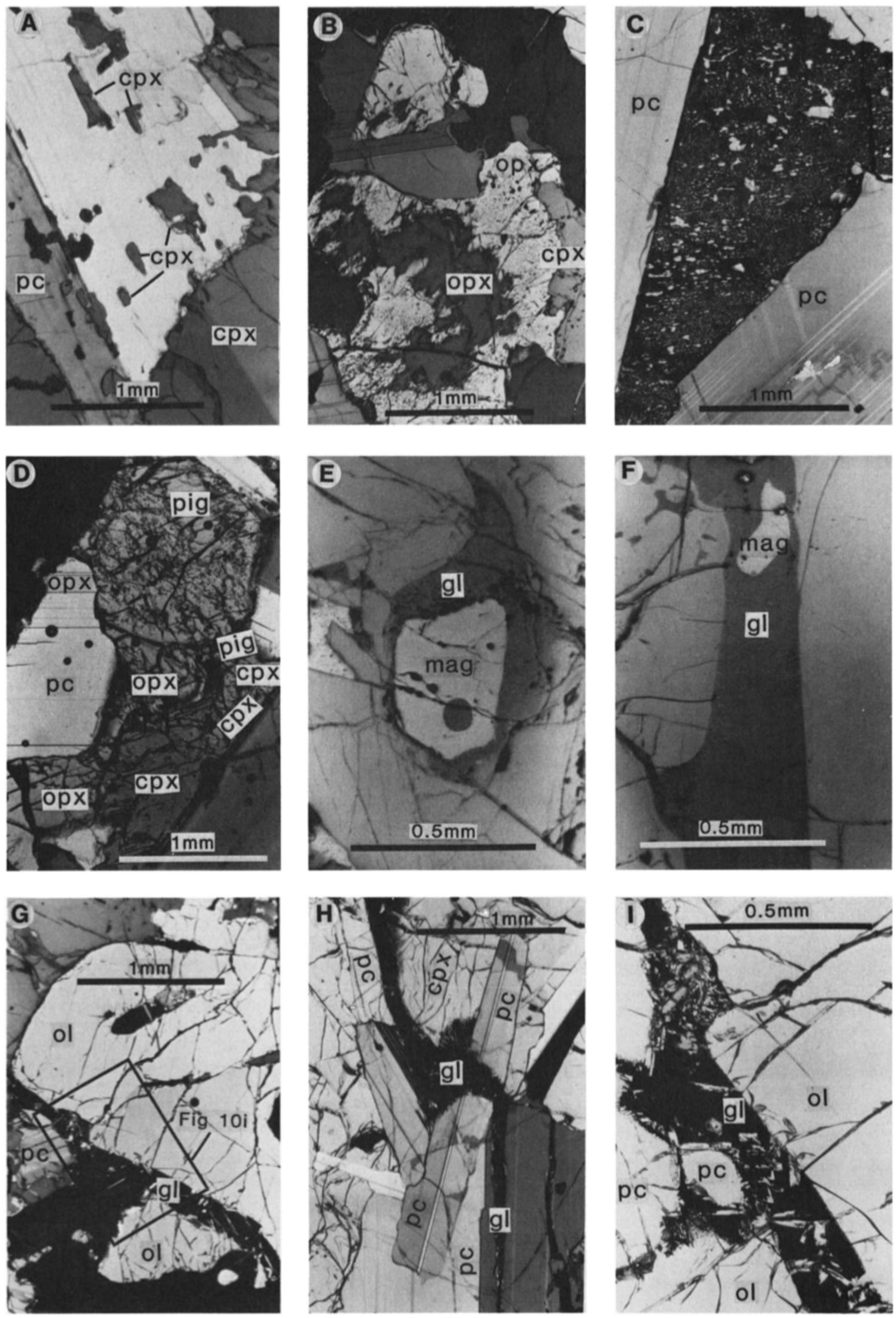
with extremely high $\mathrm{MgO}$ melts [Haggerty, 1976]. If melt composition were the only factor, then ilmenite crystallizing from extremely differentiated melt, as is indicated by the silicate mineralogy in the Juan de Fuca Ridge xenoliths, should have low MgO contents. Pinckney and Lindsley [1976] showed that the preference of $\mathrm{Mg}$ for the rhombohedral phase increases with decreasing temperature. Ilmenite grains with vastly different $\mathrm{MgO}$ contents occur within millimeters of one another; therefore it is unlikely that temperature differences caused a factor of 2 difference in $\mathbf{M g}$ content. The origin and significance of the high-Mg ilmenite is unknown.

\section{Geothermometry and Cooling Rate}

Plagiclase-melt equilibria calculations [Drake, 1976] for samples 5-7A and 8-2 indicate that the phenocrysts and microphenocrysts in the host lava are in equilibrium with a dry melt in the temperature range of $1200^{\circ}-1250^{\circ} \mathrm{C}$. The presence of water in the melt increases the An content of plagioclase [Johannes, 1978] and results in calculation of anomalously high temperatures; hence the plagioclase-melt equilibria temperatures for a dry melt are maximum temperature estimates, although the low volatile content estimates in normal MORB [Delaney et al., 1978] and ferrobasalt [Byers et al., 1983,1984 ] suggest that water in the melt should not have significantly affected plagioclase equilibrium.

Use of the Lindsley [1983] graphical geothermometer for augite in type II xenoliths yields estimates of crystallization temperatures of $1100^{\circ}-1200^{\circ} \mathrm{C}$. The temperature range for phenocrysts and microphenocrysts is $1100^{\circ}-1300^{\circ} \mathrm{C}$; these estimates are not reliable because of quenching control of $\mathrm{CaO}$ content. Subsolidus equilibrium temperatures can be estimated by using coexisting orthopyroxene-augite-pigeonite assemblages found in inverted pigeonite. Compositions of hostlamellae pairs in sample 5-8B and 5-7A yield temperature estimates of $1100^{\circ}-1150^{\circ} \mathrm{C}$ and $1130^{\circ} \mathrm{C}$, respectively. Noninverted pigeonite in sample 5-7B also yields a temperature of $1130^{\circ} \mathrm{C}$. High-Fe augite in sample 5-72 gives a temperature of $1090^{\circ} \mathrm{C}$.

The presence of exsolved Ca-rich pyroxene in pigeonite indicates slow cooling. The character of exsolution lamellae in pyroxene reflect bulk composition, maximum temperature, and cooling rate [Robinson, 1980]. Inverted pigeonite with blebby augite, similar to inverted pigeonite in the Juan de Fuca xenoliths, has been called "Kintoki-San type" [Kuno,

Fig. 9. (opposite) Photomicrographs of textures found in type III xenoliths. (a) Sample 5-8B; intergrowth texture of augite and plagioclase. Crossed nicols. (b) Sample 5-7A; blebby exsolution texture in inverted pigeonite. Plagioclase is medium grey with albite twinning in the upper part of the photo. Orthopyroxene is dark grey in the center of the pyroxene. Augite is light grey in the central right of the photo. Crossed nicols. (c) Sample 5-8B; blebby exsolution texture in inverted pigeonite. Augite is light grey and orthopyroxene is dark grey. Exsolution more aligned along crystallographic planes than in other pigeonites. Crossed nicols. (d) Sample 5-7A; blebby exsolution texture in inverted pigeonite. This sample shows the great variability in bleb width. A core of pigeonite remains in the upper central part of the photo. Crossed nicols. $(e)$ and $(f)$ Samples 5-7A and 5-8B; anhedral oxides (white) in interstitial glass (grey). Photomicrographs were taken with half reflected and half transmitted light to show position of oxides within interstitial glass. $(g)$ Sample 5-8B; melt-filled fracture through olivine crystal indicating a stage of brittle deformation. Olivine has subtle extinction discontinuity which runs approximately through the center of the photo. Olivine below the discontinuity is slightly darker grey than above: Box defines area of Figure $9 i$. Crossed nicols. (h) Sample 5-8B; melt-filled fracture through augite and plagioclase. Augite and plagioclase have started to react with the melt. Crossed nicols. (i) Sample 5-8B; close-up of fracture in Figure $9 \mathrm{~g}$. Reaction between plagioclase, olivine, and melt can be seen by the ragged crystal-melt boundaries. Crossed nicols.
1966] and has been found in plutonic [Brown, 1957] and hypabyssal [Ishii, 1973] environments. Ishii and Takeda [1974] suggest that the blebby texture is produced when pigeonite undergoes eutectoidal decomposition into orthopyroxene and augite at the temperature of the pigeonite eutectoid reaction point.

Mimimum stability temperatures for pigeonite in the xenoliths can be derived graphically from a plot of minimum stability for pure $\mathrm{Ca}-\mathrm{Mg}-\mathrm{Fe}$ pigeonite, relative to augite and orthopyroxene, as a function of $X=\mathrm{Fe}^{2+} /\left(\mathrm{Fe}^{2+}+\mathrm{Mg}\right)$ [Lindsley, 1983] and give an estimate of $1150^{\circ} \pm 30^{\circ} \mathrm{C}$. The use of minimum temperature of stability curves at low pressures of natural pigeonite, instead of pure Ca-Mg-Fe pigeonite [Ross and Huebner, 1979], results in a slightly higher estimate of $1180^{\circ} \mathrm{C}$. A minimum temperature of stability of approximately $1150^{\circ} \mathrm{C}$ is consistent with subsolidus temperatures of $1100^{\circ}$ $1150^{\circ} \mathrm{C}$ for orthopyroxene-augite pairs in inverted pigeonite.

Inverted pigeonite with blebby exsolution of augite occurs in a two-pyroxene gabbro recovered at DSDP site 334. Pigeonite from site $\mathbf{3 3 4}$ gabbro has complex exsolution patterns because equilibration to low temperatures resulted in multiple sets of exsolution lamellae [Hodges and Papike, 1976]. Pigeonite in Juan de Fuca gabbro xenoliths has simple exsolution patterns reflecting the arrested equilibrium at higher temperatures. Partly inverted pigeonite has been observed in terrestrial hypabyssal rocks, such as the Palisades Sill [Walker et al., 1973] and the Kintoki-San dike in Hakone Volcano [Ishii and Takeda, 1974], and in lunar and meteoric pyroxenes [Papike and Bence, 1972; Ghose et al., 1973; Harlow et al., 1979]. We assume that inversion of pigeonite and other subsolidus equilibration reactions in the xenoliths would have proceeded to completion had eruption and quenching not abruptly changed the rate of cooling. Therefore the similarity in texture between pigeonite from the xenoliths and that from the Palisades Sill implies that the rate of cooling of the Palisades Sill was greater than that of the magma chamber source of the xenoliths.

Estimates of temperature and $\log f_{\mathrm{O}_{2}}$ using the Stormer calculation method for composite $\mathrm{Fe}-\mathrm{Ti}$ oxides are $1027^{\circ} \mathrm{C}$ and -10.47 in sample $5-8 \mathrm{~b}$ (Pair $1+3$ ) and $1054^{\circ} \mathrm{C}$ and -9.92 in sample 5-7a (pair $6+9$ ). The composite grains should be the most reliable $T$ and $f_{\mathrm{O}_{2}}$ indicators. Calculations based on Carmichael [1967] and Lindsley and Spencer [1982] yield $T$ estimates consistently lower by $40^{\circ}-60^{\circ} \mathrm{C}$ and $\log f_{\mathrm{O}_{2}}$ lower by up to 1.30. Scatter in the estimates increases with increasing minor element contents. The use of high- $\mathrm{Mg}$ ilmenite in the magnetite-ilmenite mineral pair results in lower temperature estimates $\left(859^{\circ}-919^{\circ} \mathrm{C}\right)$ and $\operatorname{lower} \log f_{\mathrm{O}_{2}}$ estimates $(-12.5$ to -14.0). Maximum and minimum temperature and $f_{\mathrm{O}_{2}}$ estimates are shown in Table 6. Lack of optically resolvable Fe-Ti oxide exsolution indicates quenching without significant slow cooling after oxides formed.

\section{Discussion}

Textural evidence from the Juan de Fuca Ridge xenoliths suggests that the xenoliths formed by in situ crystallization near the margin of a magma chamber. Xenoliths from Juan de Fuca are characterized by random orientation of grains, wide range of grain sizes, zoning deep within the crystals in the more crystalline xenoliths, and abundant intergrowth textures. Textures characteristic of cumulate gabbros, such as homogeneous cumulate phases, limited grain size variation, and edge zoning, are not present. The Juan de Fuca Ridge xenoliths have textures similar to, except for the abundance of glass, those of high-level isotropic gabbro from the Samail ophiolite [Pallister and Hopson, 1981]. The sympathetic variation of interstitial glass, glass inclusion, and mineral compositions 


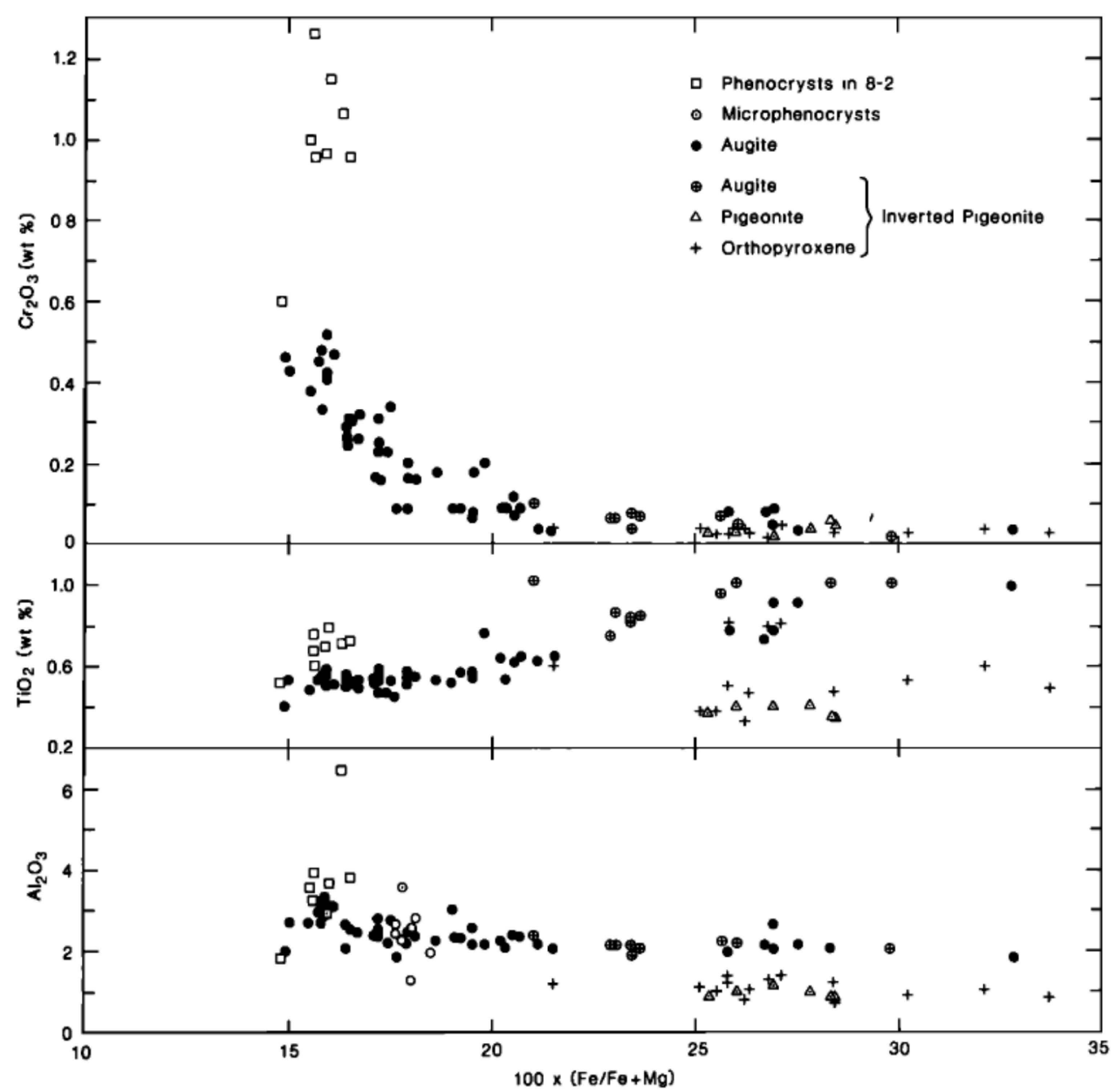

Fig. 10. Minor element variation diagram for pyroxene in host lava and xenoliths. Augite from the xenoliths (solid circles) exhibits a systematic decrease in $\mathrm{Cr}_{2} \mathrm{O}_{3}$ and $\mathrm{Al}_{2} \mathrm{O}_{3}$ and increase in $\mathrm{TiO}_{2}$ with increasing $\mathrm{Fe} /(\mathrm{Fe}+\mathrm{Mg}$ ) and can be related to a single fractionation trend. Scatter in $\mathrm{TiO}_{2}$ and $\mathrm{Al}_{2} \mathrm{O}_{3}$ contents in phenocrysts and microphenocrysts is a result of disequilibrium crystallization during rapid cooling.

support the interpretation of in situ crystallization and document the changing composition of the interstitial liquid.

Several lines of evidence indicate that the Juan de Fuca xenoliths formed by quenching of a not yet holocrystalline mush and not by partial melting of a holocrystalline gabbro. Examination of the entire textural suite shows that for the more open-textured xenoliths, euhedral grains are set in a matrix of glass. The grain size and crystallinity increase at the expense of interstitial glass. An interstitial origin for the glass in the more crystalline xenoliths is indicated by the location of glass in interstitial areas at grain contacts, homogeneity of glass within a given xenolith regardless of adjacent mineral phases, and absence of reaction textures at interstitial glassmineral contracts.

In contrast to the sharp interstitial glass-mineral boundaries, evidence of disequilibrium between melt and xenolith minerals occurs at host lava-xenolith mineral and injected melt-xenolith mineral boundaries for the most differentiated type III xenoliths. Thus some reaction between xenoliths and host lava occurred between the time of entrainment and the time of quenching on the seafloor, but evidence of partial melting to produce the interstitial glass is not present.

The response of the xenoliths to stress is a function of their texture and temperature at the time of deformation. Xenolith 17-1 has swirls of melt around the crystals, while xenoliths 5-7A and 5-8B are crosscut by melt-filled fractures. Based on the previous discussion of geothermometry, these type III xenoliths equilibrated to temperatures of approximately $1000^{\circ} \mathrm{C}$ but no lower before they were quenched at the surface. The confining pressure during fracturing is difficult to constrain because fracturing could have occurred in the magma chamber as the fragment was ripped from the wall rock, during transport to the surface, or during eruption. Nonetheless, the gabbro xenoliths were brittle enough to be fractured. Fracturing has also been documented in Cayman Trough gabbros, where Malcolm [1981] interpreted veins of clinopyroxene and brown hornblende as residual magmatic fluid injected into fractures in the gabbros near their solidus temperature.

The most striking features of the xenoliths are their evolved composition with respect to the host lava and the sharp textural contrast between the xenoliths and the nearly aphyric host lava. Crystal clots less evolved than the host lava have been found in Iceland [Larsen, 1979] and International Program of Ocean Drilling (IPOD) leg 46 site 396B [Sato et al., 1978] and are interpreted to be cognate xenoliths. Gabbro xenoliths from Iceland are most common in porphyritic basalt and can be explained by a single episode of crystallization. A large gabbroic xenolith with composition more evolved than the host melt occurs in basalt from DSDP site 504B near the Costa Rica Rift [Natland, 1983]. This single xenolith was interpreted to be a fragment removed from the walls of a 
TABLE 6. Fe-Ti Oxide Analyses

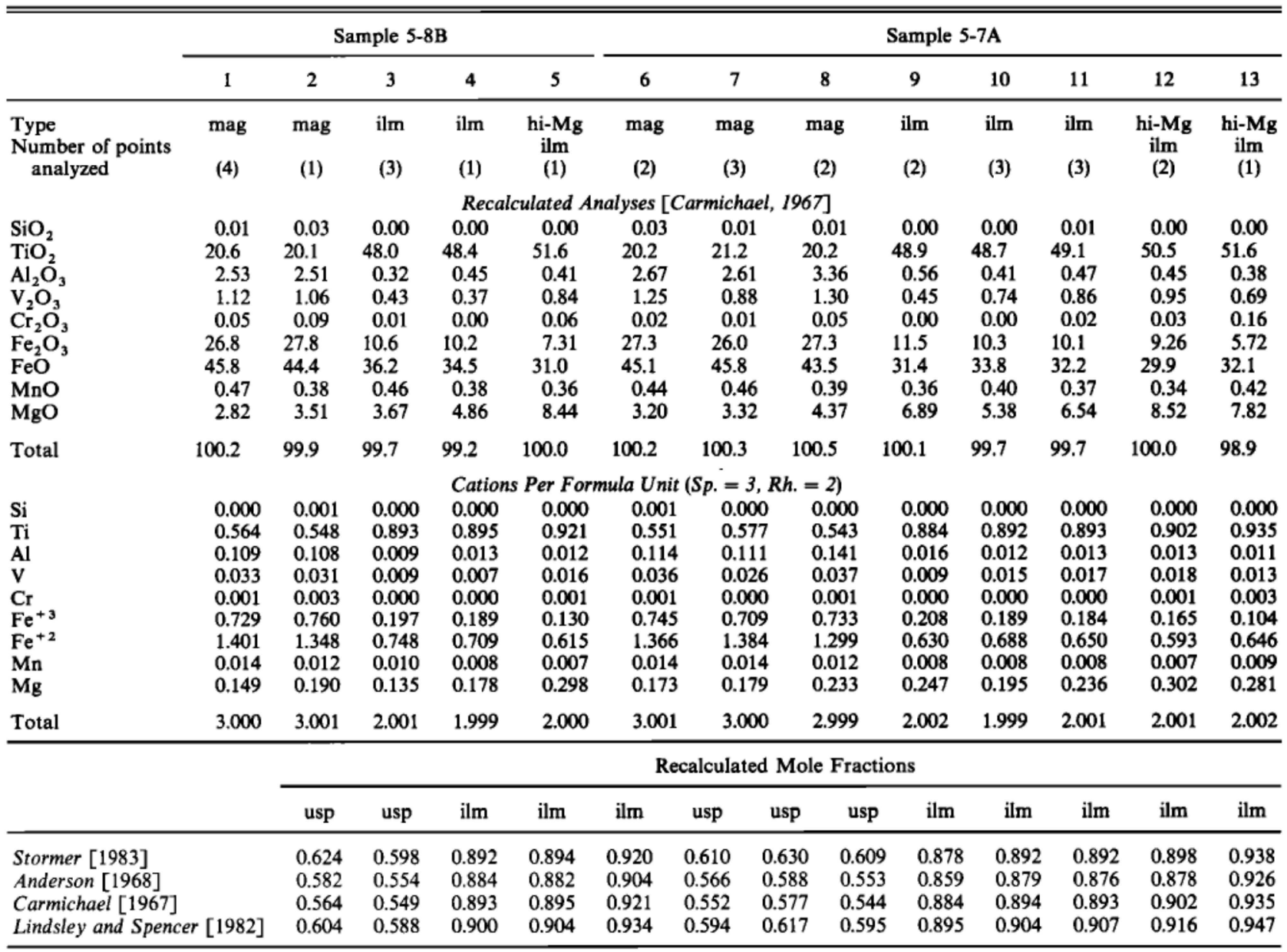

Mineral Pair Calculations (mag + ilm)

\begin{tabular}{|c|c|c|c|c|c|c|c|c|c|c|c|c|c|c|}
\hline & \multicolumn{2}{|c|}{$(1+3)$} & \multicolumn{2}{|c|}{$(2+4)$} & \multicolumn{2}{|c|}{$(2+5)$} & \multicolumn{2}{|c|}{$(6+9)$} & \multicolumn{2}{|c|}{$(7+9)$} & \multicolumn{2}{|c|}{$(8+10)$} & \multicolumn{2}{|c|}{$(8+13)$} \\
\hline & $T$ & $f_{\mathrm{O}_{2}}$ & $T$ & $f_{\mathrm{O}_{2}}$ & $T$ & $f_{\mathrm{O}_{2}}$ & $T$ & $f_{\mathrm{O}_{2}}$ & $T$ & $f_{\mathrm{O}_{2}}$ & $T$ & $f_{\mathrm{O}_{2}}$ & $T$ & $f_{\mathrm{O}_{2}}$ \\
\hline Stormer [1983] & 1027 & -10.47 & 1001 & -10.82 & 919 & -12.51 & 1054 & -9.92 & 1072 & -9.70 & 1015 & -10.61 & 859 & -13.98 \\
\hline Anderson [1968] & 1015 & -10.47 & 996 & -10.68 & 938 & -11.84 & 1058 & -9.60 & 1078 & -9.39 & 1002 & -10.55 & 869 & -13.43 \\
\hline Carmichael [1967] & 978 & -11.08 & 959 & -11.38 & 884 & -13.03 & 990 & -10.78 & 1010 & -10.53 & 963 & -11.27 & 830 & -14.35 \\
\hline Lindsley and Spencer [1982] & 988 & -11.10 & 963 & -11.51 & 861 & -13.81 & 994 & -10.92 & 1013 & -10.68 & 970 & -11.41 & 806 & -15.30 \\
\hline
\end{tabular}

Analyses 1 and 3 are from a composite grain, as are 6 and 9. Fe-Ti oxide data were obtained using an ARL-SEMQ automated nine-channel microprobe and reduced using the matrix correction program of Bence and Albee [1968]. Standards used in the analysis of Fe-Ti oxides were synthetic V-doped diopside for $\mathrm{Si}$ and $\mathrm{V} ; \mathrm{Fe}_{2} \mathrm{O}_{3} \mathrm{Fe} ; \mathrm{TiO}_{2}$ for $\mathrm{Ti}$; synthetic spinel for $\mathrm{Mg}$ and $\mathrm{Al} ; \mathrm{Mn}_{2} \mathrm{O}_{3}$ for $\mathrm{Mn}$ and Tiebaghi chromite for $\mathrm{Cr}$. Sample current was $20 \mathrm{nA}$. The vanadium intensity $\left(\mathrm{k}\right.$-alpha) was calculated by subtracting the $\mathrm{Ti}_{k-\beta}$ peak from the measured total intensity.

magma chamber or shallow conduit system that originally contained more fractionated melt. The abundance of glass and a broad spectrum of texture and compositions in the Juan de Fuca xenolith suite suggest that formation of the gabbros is intimately involved with the magma chamber and not the product of crystallization in a small isolated magma pocket. The evolved compositions suggest the existence of melt more evolved than the host melt in the magma chamber.

\section{Hawailan laya lakes: An Analogy}

A puzzling aspect of the xenoliths is the large variability in mineral modes (Table 10). Estimated bulk xenolith compositions do not, in general, reflect lava compositions. Also the dominance of augite + plagioclase xenoliths is contrary to what one would expect from simple crystallization along a liquid line of descent, which requires olivine in addition to augite + plagioclase. The problem may be one of scale. The large-scale view is one of in situ crystallization at the top of a cooling magma body, while in detail the actual processes may be extremely complex. Drill core studies of Hawaiian lava lakes; such as Kilauea Iki [Richter and Moore, 1966; Helz, 1980], Makaopuhi [Wright and Okamura, 1977], and Alae [Wright and Peck, 1978], document the small-scale complexities of crystallization in a cooling magma body.

A feature common to all the studied lava lakes in Hawaii is the presence of zones of relatively coarse-grained, glassy, vesicular segregation veins that appear to fill fractures and have high differentiated compositions [Wright and Okamura, 1977]. These segregation veins form by physical segregation of differ- 
TABLE 7. Average Interstitial Glass Analyses

\begin{tabular}{|c|c|c|c|c|c|c|c|c|c|c|c|}
\hline & \multirow{2}{*}{$\begin{array}{c}\text { Type I } \\
17-7\end{array}$} & \multicolumn{5}{|c|}{ Type II } & \multicolumn{5}{|c|}{ Type III } \\
\hline & & $17-69$ & $17-1 \mathrm{~A}$ & $5-0$ & $5-1$ & $5-72$ & $5-7 B$ & $26-1 A$ & $16-7 \mathrm{~A}$ & $17-3$ & $5-8 B$ \\
\hline $\begin{array}{c}\text { Analyses } \\
\text { average }\end{array}$ & (3) & (2) & (4) & (4) & (3) & (5) & (2) & (4) & (2) & (2) & (3) \\
\hline $\mathrm{SiO}_{2}$ & 50.6 & 50.6 & 51.4 & 50.8 & 51.6 & 51.1 & 51.3 & 51.7 & 51.4 & 51.3 & 52.7 \\
\hline & 13.7 & 14.1 & 13.7 & 13.7 & 14.0 & 14. & 13.4 & 13.9 & 13 & 13.2 & 13.1 \\
\hline $\mathrm{FeO}^{*}$ & 12.2 & 12.3 & 12.9 & 13.5 & 14.0 & 14.1 & 13.5 & 12.9 & 14.2 & 15.0 & 13.2 \\
\hline $\mathrm{MgO}$ & 6.78 & 6.65 & 6.21 & 5.77 & 5.65 & 4.90 & 6.25 & 5.42 & 5.17 & 5.04 & 3.51 \\
\hline $\mathrm{CaO}$ & 10.9 & 10.8 & 10.3 & 10.1 & 9.62 & 10.0 & 10.2 & 9.83 & 9.25 & 9.33 & 8.05 \\
\hline $\mathrm{Na}_{2} \mathrm{O}$ & 2.58 & 2.70 & 2.86 & 3.02 & 3.17 & 3.06 & 2.81 & 3.05 & 3.04 & 3.03 & 3.69 \\
\hline $\mathrm{K}_{2} \mathrm{O}$ & 0.18 & 0.18 & 0.22 & 0.22 & 0.23 & 0.21 & 0.29 & 0.30 & 0.30 & 0.27 & 0.64 \\
\hline $\mathrm{TiO}_{2}$ & 1.92 & 1.90 & 2.10 & 2.36 & 2.41 & 2.44 & 2.46 & 2.55 & 2.93 & 2.97 & 2.96 \\
\hline $\mathrm{P}_{2} \mathrm{O}_{5}$ & 0.18 & 0.20 & 0.22 & 0.26 & 0.27 & 0.23 & 0.29 & 0.30 & 0.37 & 0.33 & 0.84 \\
\hline $\mathrm{M}_{1}^{2}$ & 0.19 & 0.19 & 0.20 & 0.22 & 0.21 & 0.21 & 0.22 & 0.20 & 0.22 & 0.23 & 0.23 \\
\hline $\mathrm{SO}_{3}$ & 0.16 & 0.15 & 0.17 & 0.17 & 0.19 & 0.20 & 0.15 & 0.17 & 0.19 & 0.20 & 0.11 \\
\hline Total & 99.4 & 99.8 & 100.3 & 100.1 & 101.4 & 101.0 & 100.9 & 100.3 & 100.7 & 100.9 & 99.0 \\
\hline $\begin{array}{l}\mathrm{Mg} \# \\
\mathrm{FeO} / \mathrm{MgO} \dagger\end{array}$ & $\begin{array}{c}51.0 \\
1.62\end{array}$ & $\begin{array}{l}50.3 \\
1.67\end{array}$ & $\begin{array}{c}47.5 \\
1.87\end{array}$ & $\begin{array}{c}44.6 \\
2.11\end{array}$ & $\begin{array}{c}43.1 \\
2.24\end{array}$ & $\begin{array}{c}39.5 \\
2.59\end{array}$ & $\begin{array}{c}46.5 \\
1.94\end{array}$ & $\begin{array}{c}44.1 \\
2.14\end{array}$ & $\begin{array}{c}40.5 \\
2.48\end{array}$ & $\begin{array}{c}38.7 \\
2.68\end{array}$ & $\begin{array}{c}33.2 \\
3.38\end{array}$ \\
\hline
\end{tabular}

Analytical procedure for intersertal glasses was the same as the procedure for glassy rims, except that counting time was $120 \mathrm{~s}$.

${ }^{*} \mathrm{FeO} *$ = total $\mathrm{Fe}$ calculated as $\mathrm{FeO}$.

$\dagger \mathrm{FeO} / \mathrm{MgO}$ calculated using $0.9 \times \mathrm{FeO}^{*}$.

entiated melt by filter pressing from a rigid crystal framework. Melt, as defined by drilling, is a crystal-liquid mush too fluid to support the weight of the drill string, a condition reached when the magma contains approximately $45 \%$ glass and $55 \%$ crystals [Helz, 1980]. Wright and Peck [1978] also note that the composition of the liquid will vary in composition according to the efliciency of the filter press in separating liquid from crystals. Differences in the ratios of minerals brought in will produce a differentiate that does not lie on a "liquid line of descent." Helz [1980] documents that the total thickness of segregation veins in Kilauea Iki, the largest and most complex of the Hawaiian lava lakes, is 3-6 $\mathrm{m}$ in the central part of the lake, corresponding to $6-11 \%$ of the upper crust. Formation of segregation veins in the crystallizing zone above the southern Juan de Fuca Ridge magma chamber can explain the highly variable bulk compositions of the xenoliths and the deviation from a simple liquid line of descent.

Segregation veins need fractures to form. Fracturing in lava lakes, which are static bodies, may be associated with degassing of lava and partially molten crust. Additional large horizontal fractures may form when the upper crust becomes more or less supported by the walls of the crater and fails to track the lens of melt as it cools and solidifies [Wright and Okumura, 1977]. Mid-ocean ridge magma chambers differ from $\mathrm{Ha}$ waiian lava lakes in that volatiles are kept in solution by high hydrostatic and lithostatic loads. The absence of volatile release as a fracturing mechanism, however, is more than compensated for by active tectonics at mid-ocean ridges. Lava lake studies show that fracturing can be sustained down to the crust-melt interface. Similarly, rifting at the ridge crest in the

TABLE 8. Average Glass Inclusion Analyses

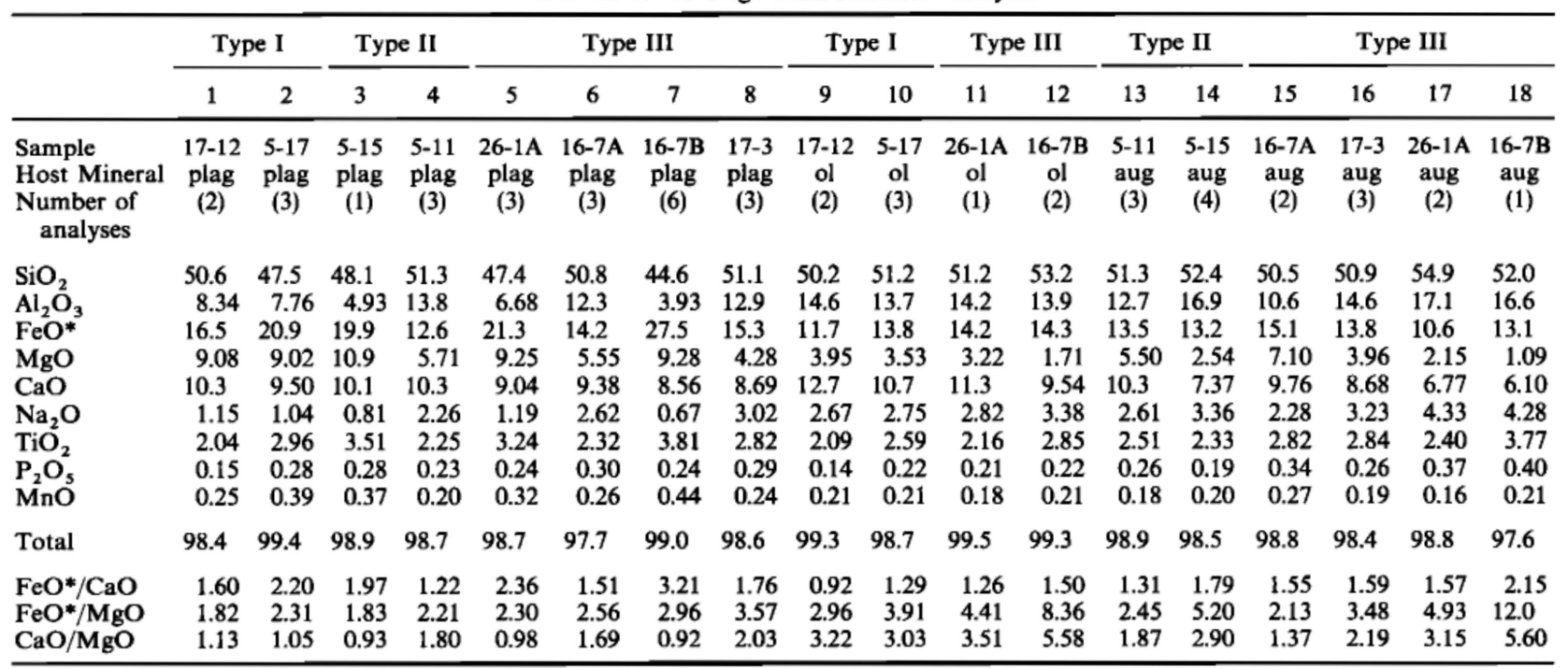




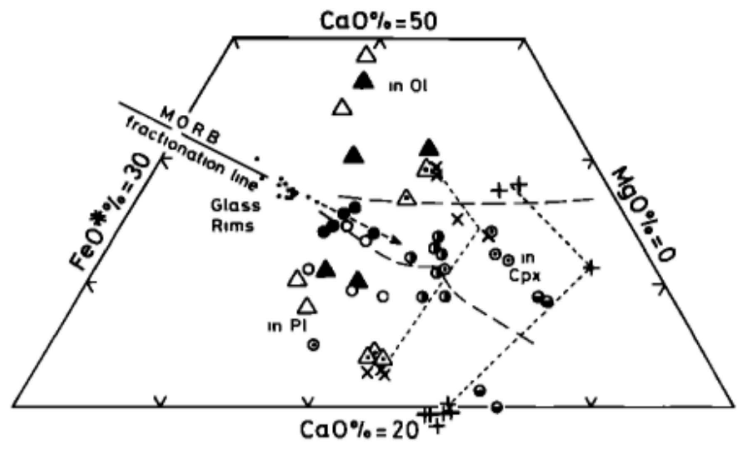

Fig. 11a. Compositions of glass inclusions trapped in xenolith minerals plotted on $\mathrm{MgO}, \mathrm{CaO}, \mathrm{FeO}^{*}$ triangular plot. Compositions of the host rock glasses (small dots) are plotted for comparison and fall on a MORB fractionation line. Symbols used are type I xenoliths: sample 5-7, solid triangle; sample 5-17, triangle with dot; sample 17-12, open triangle. Type II xenoliths: sample 5-11, solid circle, sample 5-15, circled dot; sample 16-7A, open circle; sample 17-2, horizontally half solid circle; sample $17-3$, vertically half solid circle. Type III xenoliths: sample 16-7B, cross; sample 26-1A, plus. The short dashed lines link the inclusions in the different crystals of two type II xenoliths. Long dashed lines divide the field by host minerals.

oceanic environment may cause fractures that extend to this boundary. Rifting of the oceanic crust, therefore, may cause percolation of differentiated liquids into fractures at or near the ridge crest at mid-ocean ridges.

\section{Magma Mixing and Formation of Xenoliths}

We favor a model of repetitive magma chamber replenishment to account for the presence of xenoliths within aphyric lava. Replenishment occurs before the magma chamber has completely solidified and results in mixing, rejuvenated convection, and superliquidus temperatures [Walker et al., 1979]. The boundary for rejuvenated convection would be the brittleductile boundary, approximately $45 \%$ liquid, as defined by the Hawaiian lava lake studies. The host lava is a hybrid formed by mixing highly evolved residual melt with a new batch of primitive melt [Clague et al., 1983]. Mixing is supported by the homogeneous lava composition within the axial valley and is probably controlled by density differences. Dense picritic magma may pond at the base of the magma chamber after injection as modeled by Huppert and Turner [1981]. Sparks et al. [1980] calculated that the density of picritic liquids decreases with decreasing temperature due to removal of olivine. The density of ferrobasalt, on the other hand, increases with decreasing temperature due to removal of dominantly plagioclase. Convective mixing will occur when the density of the overlying ferrobasalt is greater than or equal to the density of

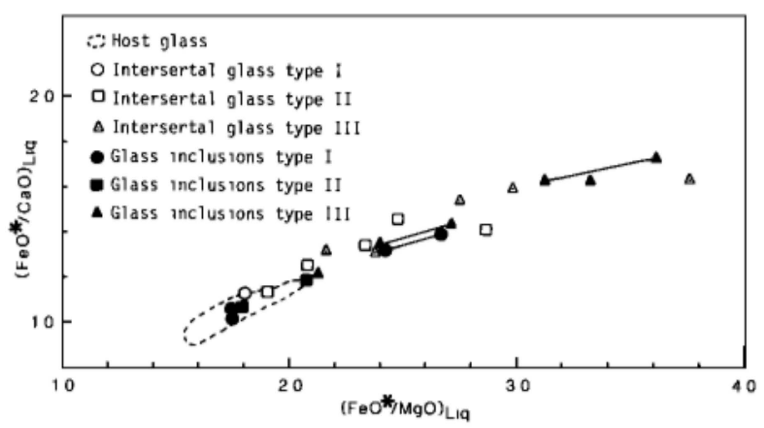

Fig. 11b. Plot of $\left(\mathrm{FeO}^{*} / \mathrm{CaO}\right)_{L_{1 q}}$ versus $\left(\mathrm{FeO}^{*} / \mathrm{MgO}\right)_{\mathrm{Liq}}$, showing the evolved compositions of interstitial glass and glass inclusions relative to host lava compositions. Lines join data from a single xenolith but from two different minerals. $\mathrm{FeO}^{*} / \mathrm{CaO}$ and $\mathrm{FeO} * / \mathrm{MgO}$ ratios calculated in glass inlusions of olivine are systematically $10-15 \%$ higher than the same ratios calculated in coexisting plagioclase. Glass inclusion data from sample 5-17, a type I xenolith, are compositionally similar to intersertal glass from type II and III xenoliths.

the underlying olivine tholeiite to picrite. Eruption may be triggered by injection of the next batch of primitive magma. The time between injections of melt must be long enough to allow mixing and resorption of phenocrysts to occur but not long enough to allow the hybrid melt to cool to the liquidus temperature when new phenocrysts would form.

The linear rift valley, abundance of sheet flows, absence of fissuring, and active hydrothermal venting in the U.S. Geological Survey (USGS) study area suggest that the magma chamber has been replenished within the last few hundred years. Initial conduit formation for the eruption fractured the crystallizing boundary zone of the magma chamber. High effusion rate eruptions of superliquidus magma, responsible for the formation of extensive aphyric sheet flows, carried the gabbro fragments to the surface.

\section{CONCLUSIONS}

Basalt from the southern Juan de Fuca Ridge is ferrobasalt derived from a depleted MORB source. Subtle differences in trace element ratios between basalt from the axial walls $(2000-$ 5000 years old) and axial valley floor (age $<1000$ years) indicate that mantle source regions for Juan de Fuca MORB are variable on a time scale of thousands to tens of thousands of years.

Rare glassy gabbroic xenoliths found in this aphyric ferrobasalt are divided into three types based on mineralogy and texture; two types are more evolved than the host lava. The coarsest-grained xenoliths equilibrated to temperatures of

TABLE 9. Estimated Initial Compositıons of Glass Inclusions

\begin{tabular}{|c|c|c|c|c|c|c|c|c|c|}
\hline & $\begin{array}{l}\text { Host } \\
\text { Glass }\end{array}$ & Type I & Type II & Type II & Type III & Type I & Type III & Type III & Type III \\
\hline Sample & & $17-12$ & $5-15$ & $5-11$ & $16-7 a$ & $5-17$ & $26-1 A$ & $16-7 \mathrm{~B}$ & $17-3$ \\
\hline $\begin{array}{l}\mathrm{FeO}^{*} / \mathrm{CaO} \\
\mathrm{FeO}^{*} / \mathrm{MgO} \\
\mathrm{CaO} / \mathrm{MgO}\end{array}$ & $\begin{array}{l}1.07 \pm 0.02 \\
1.77 \pm 0.05 \\
1.65 \pm 0.02\end{array}$ & $\begin{array}{l}1.04 \pm 0.01 \\
1.74 \pm 0.06 \\
1.68 \pm 0.04\end{array}$ & $\begin{array}{l}\cdots \\
\cdots \\
\cdots\end{array}$ & $\begin{array}{l}\ldots^{\text {Incl }} \\
\ldots \\
\ldots\end{array}$ & $\begin{array}{c}\text { ive in Olivine } \\
\ldots \\
\ldots \\
\ldots\end{array}$ & $\begin{array}{l}1.39 \pm 0.01 \\
2.67 \pm 0.06 \\
1.89 \pm 0.04\end{array}$ & $\begin{array}{l}1.43 \pm 0.01 \\
2.72 \pm 0.06 \\
1.93 \pm 0.04\end{array}$ & $\begin{array}{l}1.73 \pm 0.03 \\
3.62 \pm 0.26 \\
2.17 \pm 0.14\end{array}$ & $\begin{array}{l}\cdots \\
\cdots \\
\cdots\end{array}$ \\
\hline
\end{tabular}




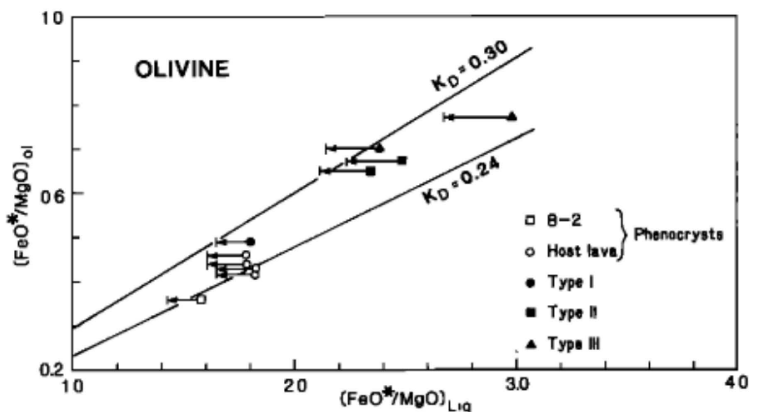

Fig. 12. Plot of $\left(\mathrm{FeO}^{*} / \mathrm{MgO}\right)_{\text {ol }}$ versus $(\mathrm{FeO} * / \mathrm{MgO})_{\mathrm{Liq}}$ showing olivine-melt equilibria based on the method of Roeder [1974]. Arrow extends from analyzed $\left(\mathrm{FeO}^{*} / \mathrm{MgO}_{\mathrm{Lig}}\right.$ (all iron as $\mathrm{FeO}$ ) to $(\mathrm{FeO} / \mathrm{MgO})_{\mathrm{Liq}}$ using $\mathrm{FeO}=0.9 \times \mathrm{FeO}^{*}$. Olivine-melt pairs are composed of phenocrysts (open square) and microphenocrysts (open circle) with host glass, and xenolith olivine with coexisting interstitial glass. Calculated $K_{D}$ for phenocrysts/microphenocryst-host glass pairs are lower than $K_{D}$ calculated for xenolith olivine-interstitial glass pairs.

$1100^{\circ}-1150^{\circ} \mathrm{C}$ based on two-pyroxene geothermometry and $1030^{\circ}-1050^{\circ} \mathrm{C}$ based on $\mathrm{Fe}-\mathrm{Ti}$ oxide geothermometry. These coàrsest-grained xenoliths were able to sustain brittle fracture. Gabbroic xenoliths represent partially crystalline wallrock formed by in situ crystallization at the top of the magma chamber. The formation of segregation veins of differentiated material by filter pressing, as documented in Hawaiian lava lake studies, may be an important process in in situ crystallization at mid-ocean ridges. Crystallization of some xenoliths from these segregation veins may explain the great variability in mineral modes and the abundance of augite + plagioclase xenoliths.

We propose that the magma chamber under the southern Juan de Fuca Ridge has undergone recent replenishment. Ferrobasalt from the southern Juan de Fuca Ridge is a hybrid melt formed by mixing of residual differentiate with more primitive melt introduced during replenishment. Total resorption of phenocrysts due to superliquidus temperatures and rejuvenated convection may be responsible for the aphyric texture of the ferrobasalt. The gabbros crystallized from evolved liquids along the cooling boundary zone of a magma chamber prior to replenishment. The xenoliths were probably carried to the surface by high-rate eruptions of superliquidus magma that resulted in extensive aphyric sheet flows.

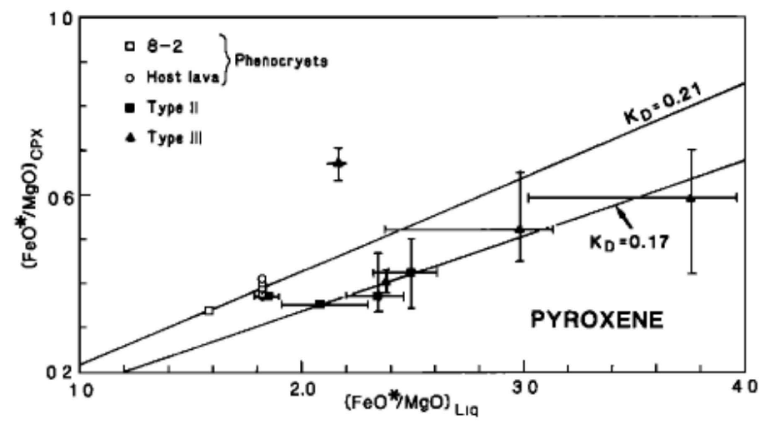

Fig. 13. Plot of $\left(\mathrm{FeO}^{*} / \mathrm{MgO}\right)_{\mathrm{CPx}}$ against $(\mathrm{FeO} * / \mathrm{MgO})_{\mathrm{Liq}}$ showing pyroxene melt equilibria. Pyroxene compositions are more evolved and variable than phenocrysts/microphenocrysts compositions. Bryan [1979] calculated a $K_{D}$ of 0.26 for pyroxene in basalt from the FAMOUS area. The one type III pyroxene with high calculated $K_{D}$ may reflect disequilibrium between pyroxene and interstitial glass due to crystallization of $\mathrm{Fe}-\mathrm{Ti}$ oxides, thereby lowering the $\mathrm{FeO} * / \mathrm{MgO}$ ratios in the glass.
TABLE 10. Xenolith Modal Mineralogy

\begin{tabular}{|c|c|c|c|c|c|c|c|}
\hline Sample & $\begin{array}{c}\text { Interstital } \\
\text { Glass }\end{array}$ & Plag & Ol & Aug & Pig & $\begin{array}{l}\text { Fe-Ti } \\
\text { Oxides }\end{array}$ & Counts \\
\hline \multicolumn{8}{|c|}{ Type I } \\
\hline $17-7$ & 28.5 & 52.1 & 19.4 & $\ldots$ & $\cdots$ & $\ldots$ & 1000 \\
\hline $17-12$ & 25.0 & 39.0 & 36.0 & $\cdots$ & $\cdots$ & $\cdots$ & 1000 \\
\hline Average* & 26.7 & 45.6 & 27.7 & $\cdots$ & $\cdots$ & $\cdots$ & \\
\hline \multicolumn{8}{|c|}{ Type II } \\
\hline $5-1$ & 16.2 & $\begin{array}{l}30.0 \\
45.4\end{array}$ & 18.2 & 20.2 & $\ldots$ & $\cdots$ & $\begin{array}{l}1000 \\
1000\end{array}$ \\
\hline $5-10$ & 48.7 & 31.7 & $\ldots$ & 19.6 & $\ldots$ & $\ldots$ & 1000 \\
\hline $5-11$ & 20.9 & 39.3 & $\cdots$ & 39.8 & $\cdots$ & $\cdots$ & 1000 \\
\hline $5-13$ & 11.9 & 45.0 & $\cdots$ & 43.1 & $\ldots$ & $\cdots$ & 1000 \\
\hline $16-5$ & 25.0 & 48.0 & $\cdots$ & 27.0 & $\cdots$ & $\cdots$ & 100 \\
\hline $16-7$ & 35.1 & 27.1 & $\ldots$ & 37.8 & $\cdots$ & $\cdots$ & 1000 \\
\hline $17-1 A$ & 51.0 & 27.5 & 1.0 & 20.5 & $\cdots$ & $\ldots$ & 1000 \\
\hline $17-2$ & 23.0 & 36.0 & $\cdots$ & 41.0 & $\cdots$ & $\cdots$ & 100 \\
\hline $17-4$ & 7.6 & 41.5 & $\cdots$ & 50.9 & $\cdots$ & $\cdots$ & 100 \\
\hline $22-25$ & 11.0 & 55.0 & $\cdots$ & 34.0 & $\cdots$ & $\cdots$ & 100 \\
\hline $22-26$ & 1.0 & 33.7 & $\cdots$ & 65.3 & $\cdots$ & $\ldots$ & 100 \\
\hline Average* & 28.3 & 36.8 & 2.6 & 32.3 & $\cdots$ & $\cdots$ & \\
\hline \multicolumn{8}{|c|}{ Type III } \\
\hline 5-7A & 1.2 & 52.4 & 38.7 & 3.7 & 4.0 & trace & 1000 \\
\hline $5-7 \mathrm{~B}$ & 19.8 & 32.1 & $\ldots$ & 48.1 & trace & $\ldots$ & 1000 \\
\hline 5-8B & 3.0 & 47.5 & 6.1 & 40.4 & 2.0 & 1.0 & 1000 \\
\hline $16-7$ & 5.5 & 56.5 & 0.5 & 34.7 & 2.8 & trace & 1000 \\
\hline $17-3$ & 4.3 & 83.0 & 2.8 & 9.9 & $\cdots$ & $\ldots$ & 1000 \\
\hline $26-1 \mathrm{~A}$ & 16.0 & 51.0 & 7.0 & 26.0 & $\cdots$ & $\ldots$ & 1000 \\
\hline Average* & 8.3 & 53.7 & 9.2 & 27.1 & 1.5 & 0.2 & \\
\hline
\end{tabular}

*Weighted by the number of points counted. Type I, type II, and type III xenoliths represent 2,80 , and $18 \%$ of the xenoliths present.

Acknowledgments. We thank the captain and crew of the S. P. Lee for their support during fair and more often foul weather. The first author would like to thank Mike Rhodes and Joel Sparks at the University of Massachusetts, Ronald B. Gilmore Memorial Laboratory for their guidance in XRF analysis and Lew Calk for assistance in operation of the USGS microprobe. We would also like to thank Kay McDaniel for typing the tables. Thoughtful reviews by Charlie Bacon, Rosalind Helz, John Sinton, and Mike Dungan improved the manuscript. The third author thanks the French Ministere des Relations Exterieures for providing a grant in support of a year of work at the U.S. Geological Survey.

\section{REFERENCES}

Allegre, C. J., B. Dupre, and B. Hamelin, Geochemistry of oceanic ridge basalts explained by blob mantle mixing, Eos Trans. AGU, $64,324,1983$.

Anderson, A. T., Oxidation of the LaBlache Lake titaniferous magnetite deposit, Quebec, J. Geol., 76, 528-547, 1968.

Batiza, R., Inverse relationship between $\mathrm{Sr}$ isotope diversity and rate of oceanic volcanism has implications for mantle heterogeneity, Nature, 309, 440-441, 1984.

Beeson, M. H., A computer program for processing electron microprobe data, U.S. Geol. Surv. Open File Rep., 40 pp., 1967.

Bence, A. E., and A. L. Albee, Empirical correction factors for the electron microanalysis of silicates and oxides, J. Geol., 76, 382-403, 1968.

Brown, G. M., Pyroxenes from the early and middle stages of fractionation of the Skaergaard intrusion, East Greenland, Mineral. Mag., 31, 511-543, 1957.

Bryan, W. B., Regional variation and petrogenesis of basalt glasses from the FAMOUS area, Mid-Atlantic Ridge, J. Petrol., 20, 293$325,1979$.

Bryan, W. B., and J. G. Moore, Compositional variations of young basalts in the Mid-Atlantic Ridge rift valley near lat $36^{\circ} 49^{\prime} \mathrm{N}$, Geol. Soc. Am. Bull., 88, 556-570, 1977.

Bryan, W. B., G. Thompson, and P. J. Michael, Compositional variation in a steady-state zoned magma chamber: Mid-Atlantic Ridge at $36^{\circ} 50^{\prime} \mathrm{N}$, Tectonophysics, 55, 63-85, 1979.

Byerly, G., The nature of differentiation trends in some volcanic rocks from the Galapagos spreading center, J. Geophys. Res., 85, 3797$3810,1980$. 
Byerly, G. R., W. G. Melson, and P. R. Vogt, Rhyodacites, andesites, ferrobasalts and ocean tholeites from the Galapagos spreading center, Earth Planet. Sci. Lett., 30, 215-221, 1976.

Byers, C. D., D. W. Muenow, and M. O. Garcia, Volatiles in basalts and andesites from the Galapagos Spreading Center, $85^{\circ}$ to $86^{\circ} \mathrm{W}$ Geochim. Cosmochim. Acta, 47, 1551-1558, 1983.

Byers, C. D., D. M. Christie, D. W. Muenow, and J. M. Sinton, Volatile contents and ferric-ferrous ratios of basalt, ferrobasalt, andesite and rhyodacite glasses from the Galapagos $95.5^{\circ} \mathrm{W}$ propagating rift, Geochim. Cosmochim. Acta, 48, 2239-2245, 1984.

Carmichael, I. S. E., The iron-titanium oxides of salic volcanic rocks and their associated ferromagnesian silicates, Contrib. Mineral. Petrol., 14, 36-64, 1967.

Carstens, H., Note on the distribution of some minor elements in coexisting ortho- and clinopyroxene, Nor. Geol. Tidsskr., 38, 257$260,1958$.

CAYTROUGH, Geological and geophysical investigation of the Mid-Cayman Rise spreading center: Initial results and observations, in Deep Drilling Results in the Atlantic Ocean: Ocean Crust Maurice Ewing Ser., vol. 2. Edited by M. Talwani, C. E. Harrison, and D. E. Hayes, pp. 66-95, AGU, Washington, D. C., 1979.

Clague, D. A., and T. E. Bunch, Formation of ferrobasalt at East Pacific midocean spreading centers, J. Geophys. Res., 81, 42474256, 1976.

Clague, D. A., F. A. Frey, G. Thompson, and S. Rindge, Minor and trace element geochemistry of volcanic rocks dredged from the $\mathrm{Ga}$ lapagos spreading center: Role of crystal fractionation and mantle heterogeneity, J. Geophys. Res., 86, 9469-9482, 1981.

Clague, D. A., J. S. Eaby, and J. R. Delaney, Petrologic evidence for long-lived axial magma chambers on the Juan de Fuca Ridge, paper presented at the Fifth Annual Geodynamics Research Symposium on Oceanic Lithosphere: Origin, Structure, and Dynamics, Tex. A\&M Univ., College Station, Tex., 1983.

Clocchiatti, R., Les liquidus silicates pieges dans lse cristaux d'olivine, de plagioclase et de pyroxene: prise d'essai du magma. Application a un basalte a affinite tholeitique de la ride oceanique emergee d'Asal, C. R. Hebd. Seances Acad. Sci., 284, 2203-2206, 1977.

Clocchiatti, R., Glassy inclusions in plagioclase and pyroxene phenocrysts in the chilled margin of a pillow lava from hole 417D, Deep Sea Drilling Project, Initial Rep. Deep Sea Drill. Proj., 51-53, part 2. 1063-1067, 1980.

Cohen, R. S., and R. K. O'Nions, The lead, neodymium and strontium isotopic structure of ocean ridge basalts, J. Petrol., 23, 299$324,1982$.

Delaney, J. R., D. W. Muenow, and D. G. Graham, Abundance and distributions of water, carbon and sulfur in the glassy rims of submarne pillow basalts, Geochim. Cosmochim. Acta, 42, 581-594, 1978.

Delaney, J. R., J. L. Karsten, and D. A. Clague, Geochemistry of Juan de Fuca Ridge basaltic glasses, Eos Trans. AGU, 63, 1147, 1982.

Detrick, R. S., and W. S. Lynn, The origin of high-amplitude magnetic anomalies at the intersection of the Juan de Fuca Ridge and Blanco Fracture Zone, Earth Planet. Sci. Lett., 26, 105-113, 1975.

DeVore, G. W., Crystal growth and the distribution of elements, $J$. Geol., 63, 471-494, 1955.

DeVore, G. W., The association of strongly polarizing cations with weakly polarizing cations as a major influence in element distribution, mineral composition, and crystal growth, J. Geol., 65, 178$195,1957$.

Drake, M. J., Plagioclase-melt equilibria, Geochm. Cosmochim. Acta, 40, 457-465, 1976.

Dungan, M. A., and J. M. Rhodes, Residual glasses and melt inclusions in basalts from DSDP legs 45 and 46: Evidence for magma mixing, Contrib. Mineral. Petrol., 67, 417-431, 1978.

Eaby, J. S., and D. A. Clague, Preliminary description of basalt from the southern Juan de Fuca Ridge, U.S. Geol. Surv. Open File Rep. 82-200C, 17 pp., 1982.

Eaby, J., D. A. Clague, and J. R. Delaney, $\mathrm{Sr}$ isotopic variations along the Juan de Fuca Ridge, J. Geophysical Res., 89, 7883-7890, 1984.

Engel, C. G., and R. L. Fisher, Granitic to ultramafic rock complexes of the Indian Ocean ridge system, western Indian Ocean, Geol. Soc. Am. Bull., 86, 1553-1578, 1975.

Flower, M. F. J., Cryptocumulate tholeiite as evidence for magma mixing at an intermediate-rate spreading axis, Nature, 229, 542 $545,1982$.

Fornari, D. J., M. R. Perfit, A. Malahoff, and R. Embley, Geochemical studies of abyssal lavas recovered by DSRV Alvin from eastern Galapagos rift, Inca transform, and Ecuador rift, 1, Major element variations in natural glasses and spacial distribution of lavas, $J$. Geophys. Res., 88, 10,519-10,529; 1983.

Fox, P. J., and J. B. Stroup, The plutonic foundation of the oceanic crust, in The Sea, vol. 7, The Oceanic Lithosphere, edited by C. Emiliani, pp. 119-218, Wiley-Interscience, New York, 1981.

Ghose, S., I. S. McCallum, and E. Tidy, Luna 20 pyroxenes: Exsolution and phase transformation as indicators of petrologic history, Geochim. Cosmochim. Acta, 37, 831-839, 1973.

Haggerty, S. E., Opaque mineral oxides in terrestrial igneous rocks, Short Course Notes Mineral. Soc. Am., 3, H-101-H-169, 1976.

Harlow, G. E., C. E. Nehru, M. Prinz, G. J. Taylor, and K. Keil, Pyroxenes in Serra de Mage: Cooling history in comparison with Moama and Moore County, Earth Planet. Sci. Lett., 43, 173-181, 1979.

Hebert, R., D. Bibeau, and R. Hekinian, Ultramafic and mafic rocks from the Garret Transform fault near $13^{\circ} 30^{\prime} \mathrm{S}$ on the East Pacific Rise: igneous petrology, Earth Planet. Sci. Lett., 65, 107-125, 1983.

Hekinıan, R., and M. Hoffert, Rate of palagonitization and manganese coating on basaltic rocks from the rift valley in the Atlantic ocean near $36^{\circ} 50^{\prime}$ north, Mar. Geol., 19, 91-109, 1975.

Helz, R. T., Crystallization history of Kilauea Iki lava lake as seen in drill core recovered in 1967-1979, Bull. Volcanol., 43, 675-701, 1980 .

Hess, H. H., Stillwater igneous complex, Montana: A quantitative mineralogical study, Mem. Geol. Soc. Am., 80, 230 pp., 1960.

Hodges, F. N., and J. J. Papike, DSDP site 334: Magmatic cumulates from oceanic layer 3, J. Geophys. Res., 81, 4135-4151, 1976.

Huppert, H. E., and J. S. Turner, A laboratory model of a replenished magma chamber, Earth Planet. Sci. Lett., 54, 144-152, 1981.

Ishii, T., Zoning, exsolution and phase equilibria in the Kintoki-san pyroxenes, Hakone volcano, paper presented at 80th Annual Meeting, Geol. Soc. of Jpn., Sendai, 1973.

Ishii, T., and H. Takeda, Inversion, decomposition and exsolution phenomena of terrestrial and extraterrestrial pigeonites, Geol. Soc. Jpn. Mem., II, 19-36, 1974

Johannes, W., Melting of plagioclase in the systems $\mathrm{Ab}-\mathrm{An}-\mathrm{H}_{2} \mathrm{O}$ and Qz-Ab-An- $\mathrm{H}_{2} \mathrm{O}$ at $\mathrm{PH}_{2} \mathrm{O}=5$ kbars: An equilibripm problem, Contrib. Mineral. Petrol., 66, 295-303, 1978.

Kay, R., N. J. Hubbard, and P. W. Gast, Chemical characteristics and origin of oceanic ridge volcanic rocks, J. Geophys. Res., 75, 1585$1613,1970$.

Koski, R. A., R. Goodfellow, and R. M. Bouse, Preliminary description of massive sulfide samples from the Juan de Fuca Ridge, U.S Geol. Surv. Open File Rep., 82-200B, 21 pp., 1982.

Kuno, H., Review of pyroxene relations in terrestrial rocks in the light of recent experimental works, Mineral. J., S, 21-43, 1966.

Larsen, J. G., Glass-bearing gabbro inclusions in hyaloclastites from Tindfjallajokull, Iceland, Lithos, 12, 289-302, 1979.

LeRoex, A. P., H. J. B. Dick, A. J. Erlank, A. M. Reid, F. A. Frey, and S. R. Hart, Geochemistry, mineralogy and petrogenesis of lavas erupted along the southwest Indian ridge between the Bouvet triple junction and 11 degrees east, J. Petrol., 24, 267-318, 1983.

Lichtman, G. S., W. R. Normark, J. R. Delaney, J. L. Morton, H. P Johnson, and J. L. Karsten, Photogeology and evolution of the Juan de Fuca Ridge, U.S. Geol. Surv. Open File Rep. 83-464, 14 pp., 1983.

Liias, R. A., and J. M. Rhodes, Evolution of basaltic magma along the Juan de Fuca Ridge, Eos Trans. AGU, 63, 1147, 1982.

Lindsley, D. H., Pyroxene thermometry, Am. Mineral., 68, 477-493, 1983.

Lindsley, D. H., and D. J. Andersen, A two-pyroxene thermometer, Proc. Lunar Planet. Sci. Conf. 13th, Part 2, J. Geophys. Res., 88, suppl., A887-A906, 1983.

Lindsley, D. H., and K. J. Spencer, Fe-Ti oxide geothermometry: Reducing analyses of coexisting Ti-magnetite (Mt) and ilmenite (Ilm), Eos Trans. AGU, 63, 471, 1982.

Macdonald, K. C., Mid-ocean ridges: Fine scale tectonic, volcanic and hydrothermal processes within the plate boundary zone, Annu. Rev. Earth Planet. Sci., 10, 155-190, 1982.

Malcolm, F. L., Microstructures of the Cayman Trough gabbros, $J$. Geol., 89, 675-688, 1981.

Mattey, D. P., and I. D. Muir, Geochemistry and mineralogy of basalts from the Galapagos spreading center, Deep Sea Drilling Project leg 54, Initial Rep. Deep Sea Drill. Proj., 54, 755-772, 1980.

Mazzullo, L. J., and A. E. Bence, Abyssal tholeiites from DSDP leg 34: The Nazca plate, J. Geophys. Res., 81, 4327-4351, 1976.

Miyashiro, A., and F. Shido, Differentiation of gabbros in the MidAtlantic Ridge near $24^{\circ} \mathrm{N}$, Geochem. J., 14, 145-154, 1980. 
Morton, J. L., Oceanic spreading centers: Axial magma chambers, thermal structure, and small scale ridge jumps, $\mathrm{Ph}$. $\mathrm{D}$. thesis, 101 pp., Stanford Univ., Stanford, Calif., 1984.

Morton, J. L., J. S. Eaby, W. R. Normark, J.-P. Eissen, M. Golan-Bac, J. B. Rapp, and J. M. Been, Basalt samples and water- column samples from the southern Juan de Fuca Ridge: Preliminary results of cruise L13-82-WF, U.S. Geol. Surv. Open File Rep., 83-827, 15 pp., 1983.

Natland, J. H., Eflect of axial magma chambers beneath spreading centers on the compositions of basaltic rocks, Initial Rep. Deep Sea Drill. Proj., 54, 833-850, 1980.

Natland, J. H., A compositionally nearly steady-state magma chamber at the Costa Rica Rift: Evidence from basalt glass and mineral data, Deep Sea Drilling Project sites 501, 504, 505, Initial Rep. Deep Sea Drill. Proj., 69, 811-858, 1983.

Normark, W. R., J. E. Lupton, J. W. Murray, R. A. Koski, D. A. Clague, J. L. Morton, J. R. Delaney, and H. P. Johnson, Polymetallic sulfide deposits and water-column tracers of active hydrothermal vents on the southern Juan de Fuca Ridge, Mar. Technol. Soc. J., 16, 46-53, 1982.

O'Hara, M. J., Geochemical evolution during fractional crystallization of a peridically refilled magma chamber, Nature, 266, 503-508, 1977.

Pallister, J. S., and C. A. Hopson, Samail ophiolite plutonic suite: Field relations, phase variation, cryptic variation and layering, and a model of a spreading ridge magma chamber, J. Geophys. Res., 86, 2593-2644, 1981.

Papike, J. J., and A. E. Bence, Apollo 14 inverted pigeonites: Possible samples of lunar plutonic rocks, Earth Planet. Sci. Lett., 14, 176$182,1972$.

Perfit, M. R., and D. J. Fornari, Geochemical studies of abyssal lavas recovered by DSRV Alvin from eastern Galapagos rift, Inca transform, and Ecuador rift, 2, Phase chemistry and crystallization history, J. Geophys. Res., 88, 10,530-10,550, 1983.

Perfit, M. R., D. J. Fornari, A. Malahoff, and R. W. Embley, Geochemical studies of abyssal lavas recovered by DSRV Alvin from eastern Galapagos rift, Inca transform, and Ecuador rift, 3, Trace element abundances and petrogenesis, J. Geophys. Res., 88, 10,551$10,572,1983$.

Pinckney, L. R., and D. H. Lindsley, Effects of magnesium on Irontitanium oxides, Geol. Soc. Am. Abstr. Programs, 8 1051, 1976.

Richter, D. H., and J. G. Moore, Petrology of the Kilauea Iki lava lake, Hawaii, U.S. Geol. Surv. Prof. Pap., 537-B, 26 pp., 1966.

Robinson, P., The composition space of terrestrial pyroxenesInternal and external limits, in Pyroxenes, Rev. Mineral., vol. 7, edited by C. T. Prewitt, pp. 419-475, Mineralogical Society of America, Washington, D. C., 1980.

Roedder, E., Origin and significance of magmatic inclusions, Bull. Mineral., 102, 487-520, 1979.

Roeder, P. L., Activity of iron and olivine solubility in basaltic liquids, Earth Planet. Sci. Lett., 23, 397-410, 1974.

Ross, M., and J. S. Huebner, Temperature-composition relationships between naturally occurring augite, pigeonite and orthopyroxene at one bar pressure, Am. Mineral., 64, 1133-1155, 1979.

Sato, H., K. Aoki, K. Odamoto, and B. Fujita, Petrology and chemistry of basaltic rocks from hole 396B, IPOD/DSDP leg 46, Initial Rep. Deep Sea Drill. Proj., 46, 115-141, 1978.

Scheidegger, K. F., Temperatures and compositions of magmas ascending along midocean ridges, J. Geophys. Res., 78, 3340-3355, 1973.

Schilling, J.-G., G. Cousens, R. L. Chase, and J. R. Delaney, Juan de Fuca-Explorer Ridge: Rare earth contents, Eos Trans. $A G U, 63$, 1154, 1982.

Sinton, J. M., D. S. Wilson, D. M. Christie, R. N. Hey, and J. R. Delaney, Petrologic consequences of rift propagation on oceanic spreading ridges, Earth Planet. Sci. Lett., 62, 193-207, 1983.

Sobolev, V. S., and V. P. Kostyuck, Magmatic crystallisation based on a study of melt inclusions (in Russian), Nauka Press, Novosibirsk, 1975. (Translated in part in Fluid Inclusion Res., 9, 182-253, 1975.)
Sparks, R. S. J., P. Meyer, and H. Sigurdsson, Density variation amongst mid-ocean ridge basalts: Implications for magma mixing and the scarcity of primitive lavas, Earth Planet. Sci. Lett., 46, $419-430,1980$.

Stakes, D. S., J. W. Shervais, and C. A. Hopson, The volcanic- tectonic cycle of the FAMOUS and AMAR valleys, Mid-Atlantic Ridge $\left(36^{\circ} 47^{\prime} \mathrm{N}\right)$ : Evidence from basalt glass and phenocrysts compositional variations for a steady state magma chamber beneath the valley midsections, AMAR 3, J. Geophys. Res., 89, 6995-7028, 1984.

Stormer, J. C., Jr., The effects of recalculation on estiamtes of temperature and oxygen fugacity from analyses of multicomponent irontitanium oxides, Am. Mineral., 68, 586-594, 1983.

Tiezzi, L. J., and R. B. Scott, Crystal Fractionation in a cumulate gabbro, Mid-Atlantic Ridge, $26^{\circ} \mathrm{N}$, J. Geophys. Res., 85, 5438-5454, 1980.

Truter, F. C., Modern concepts of the Bushveld Igneous Complex Rep. 1, pp. 77-92, Comm. for Tech. Coop. in Afr., South. Reg. Comm. of Geol., Salisbury, 1955.

Usselman, T. M., and D. S. Hodge, Thermal control of low-pressure fractionation processes, J. Volcanol. Geotherm. Res., 4, 265-281, 1978.

van Andel, T. H., and R. D. Ballard, The Galapagos Rift at $86^{\circ} \mathrm{W}, 2$, Volcanism, structure, and evolution of the rift valley, J. Geophys. Res., 84, 5390-5406, 1979.

Vanko, D. A., and R. Batiza, Gabbroic rocks from the Mathematician Ridge failed rift, Nature, 300, 742-744, 1982.

Verma, S. P., and J.-G. Schilling, Galapagos hot spot-spreading center system, $2,{ }^{87} \mathrm{Sr} /{ }^{86} \mathrm{Sr}$ and large ion lithophile element variations $\left(85^{\circ} \mathrm{W}-101^{\circ} \mathrm{W}\right)$, J. Geophys. Res., 87, 10,838-10,856, 1982.

Vogt, P. R., and G. R. Byerly, Magnetic anomalies and basalt composition in the Juan de Fuca-Gorda Ridge Area, Earth Planet. Sci. Lett., 33, 185-207, 1976.

Wager. L. R., and W. A. Deer, Geological investigations in East Greenland, III, The petrology of the Skaergaard intrusion, Kangerdlugssuaq, East Greenland, Medd. Gronl., 105, 1-352, 1939.

Wakeham, S. E., Petrochemical patterns in young pillow basalts dredged from Juan de Fuca and Gorda ridges, M. S. thesis, Oreg. State Univ., Corvallis, 1977.

Walker, D., T. Shibata, and S. E. DeLong, Abyssal tholeiites from the Oceanographer Fracture Zone, II, Phase equilibria and mixing, Contrib. Mineral. Petrol., 70, 111-125, 1979.

Walker, K. R., N. G. Ware, and J. F. Lovering, Compositional variations in the pyroxenes of differentiated Palisades Sill, New Jersey, Geol. Soc. Am. Bull., 84, 89-110, 1973.

Watson, E. B., Glass inclusions as samples of early magmatic liquid: Determinative method and application to a South Atlantic basalt, J. Volcanol. Geotherm. Res., 1, 73-84, 1976.

Wilson, D. S., R. N. Hey, and C. Nishimura, Propagation as a mechanism of reorientation of the Juan de Fuca Ridge, J. Geophys. Res., 89, 9215-9225, 1984.

Wright, T. L., and R. T. Okamura, Cooling and crystallization of tholeitic basalt, 1965 Makopuhi lava lake, Hawaii, U.S. Geol. Surv. Prof. Pap., 1004, 78 pp., 1977.

Wright, T. L., and D. L. Peck, Crystallization and differentiation of the Alae magma, Alae lava lake, Hawaii, U.S. Geol. Surv. Prof. Pap., 935.C, 20 pp., 1978

D. A. Clague, U.S. Geological Survey, 345 Middlefield Road, MS/999, Menlo Park, CA 94025.

J. E. Dixon, Division of Geological and Planetary Sciences, 170-25, California Institute of Technology, Pasadena, CA 91125.

J.-P. Eissen, ORSTOM, B.P. A5, Noumea, New Caledonia.

(Received July 22, 1985;

revised October 15, 1985;

accepted November 1, 1985.) 